Computerized Treatment Planning and its

Realization in Maxillofacial Surgery and in Dental Implantology

Ph.D. Thesis

Dr. Med. Dent. Endre Varga Jr.

Supervisors: Prof. Dr. Dr. József Piffkó

Prof. Dr. Endre Varga

Faculty of Medicine,

University of Szeged

Szeged, Hungary 2014 


\section{Publications Related to the Thesis}

I.

Varga E Jr, Hammer B, Hardy BM, Kamer L

The accuracy of three-dimensional model generation. What makes it accurate to be used for surgical planning? Int J Oral Maxillofac Surg 2013 Sep;42(9):1159-66.

IF: 1,521

II.

Seres L, Varga E Jr, Kocsis A, Rasko Z, Bago B, Varga E, Piffko J

Correction of a Severe Facial Asymmetry with Computerized Planning and with the use of a Rapid Prototyped Surgical Template: a case report/technique article. Head Face Med 2014 5532883321288826

IF: 0,981

III.

Varga E Jr, Czinkóczky B, Korpásy V

CAD/CAM technológia alkalmazása az implantációs sebészetben és protetikában. Magyar Fogorvos 2012/6 283

IV.

Varga E Jr, Erdőhelyi B, Bagó B

Eljárás és rendszer implantációs sablon tervezésére és előállítására

Szabadalmi bejelentés alapszáma: P1400255. 


\section{Table of Contents}

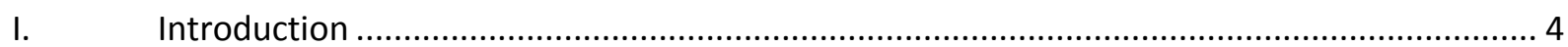

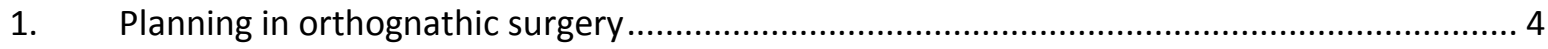

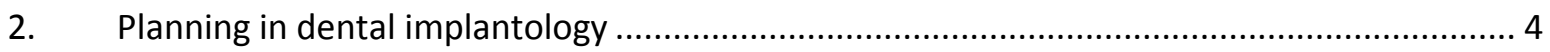

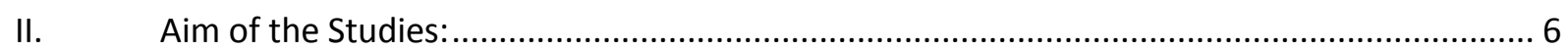

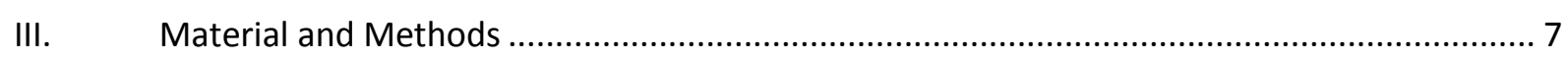

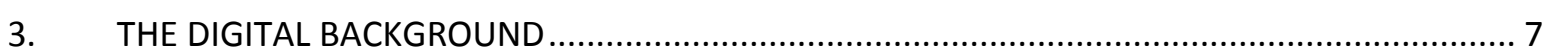

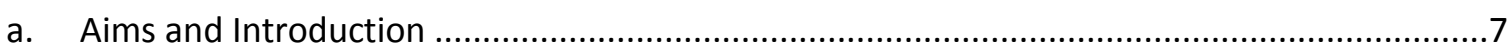

b. The accuracy of three-dimensional model generation. What makes it accurate to be

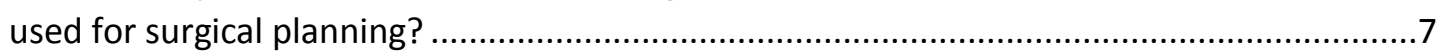

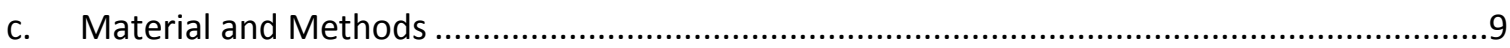

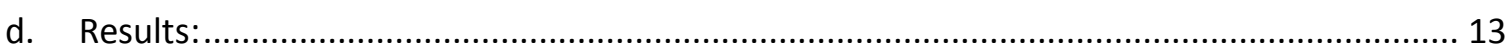

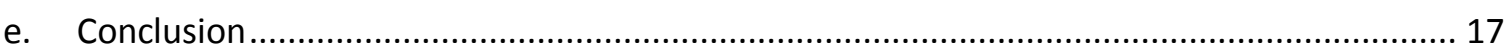

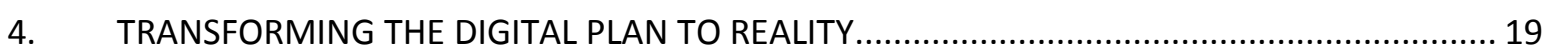

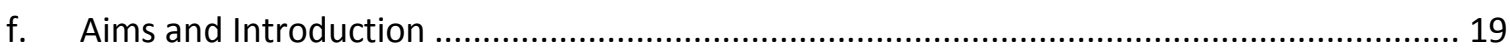

g. Evaluation of the Accuracy of Ten Clinical Orthognathic Cases ....................................... 19

h. Correction of a Severe Facial Asymmetry with Computerized Planning and with the Use of a Rapid Prototyped Surgical Template: a Case Report / Technique Article .............. 22

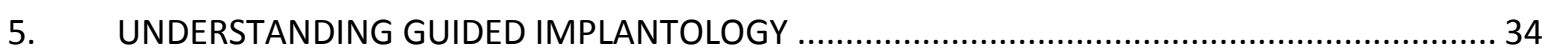

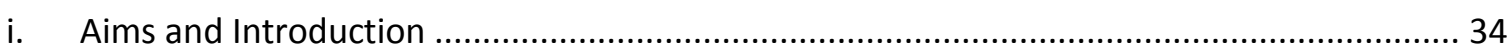

j. $\quad$ The Use of CAD/CAM Technology in Implant Surgery and Prosthetics. ..............................34

k. Method and System for Designing and Manufacturing Surgical Guides ............................ 40

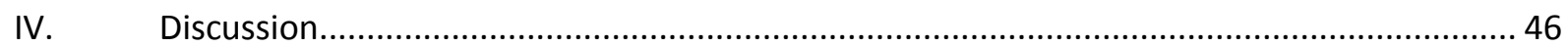

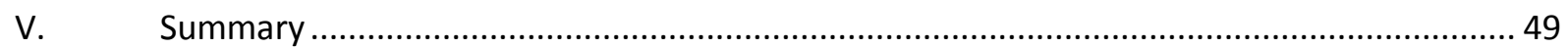

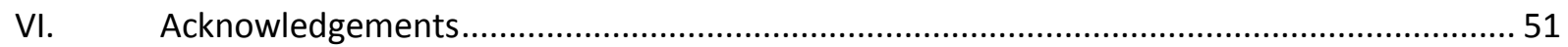

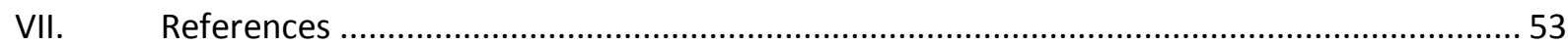

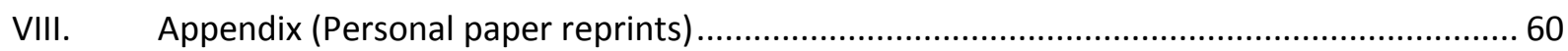




\section{Introduction}

Patients undergoing surgical procedures in the maxillofacial region have high expectations of treatment outcomes. The results of these procedures have immense aesthetic impact on the human face. Precise planning and accurate implementation of the plan during operation have key roles in the result. This thesis focuses on the importance of medical imaging, image processing, accuracy and the usability of planning systems. The research shown in this work combines orthognathic surgery and dental implantology as these fields have the uppermost patient demands and therefore require the highest accuracy.

\section{Planning in orthognathic surgery}

Correction of facial asymmetry is often a challenging task due to the spatial complexity and the relation of the dentition, bony structures and soft tissues. Therefore the aim for better visualization of the structures, information flow between professionals without detail loss and thus improving surgical outcome is a current topic. The need for the third dimension in orthognathic planning appeared together with modern computers (Lambrecht and Brix 1989). Existing two-dimensional planning is sophisticated with superimposition of the cephalogram and profile image allowing the clinician to plan the surgery to closely match the desired result (Sarver 1993). Rapid prototyping techniques gave the opportunity to manufacture the virtual data and perform pre-surgeries on the actual patient model (Ribas et al 2001). The fast development of computer science allowed surgeons to begin to manipulate virtual bony segments in three dimensions (Alves 2007). The spreading of rapid prototyping techniques led to improvements in the realization of the virtual plan. Three-dimensional printers were not only able to print bony segments but also to manufacture individualized surgical wafers with the use of planning programs (Metzger et al 2008, Swennen et al 2009, Hernández-Alfaro et al 2013, Cousley and Turner 2014).

\section{Planning in dental implantology}

Implant procedures are often difficult to perform due to the various anatomy of the alveolar bone (Chappuis et al 2013, Nunes et al 2013), the alveolar nerve (Bogdán et al 2006) and the 
maxillary sinus (Xu et al 2011). Positioning of dental implants has major effects on the surrounding bone, periodontal soft-tissue and prosthetics. These factors have determinative roles in long-term implant survival. The introduction of cone beam computed tomography (CBCT) increased visualization of the dental and alveolar structures in a new level (Ikuma 1995). This technology opened new fields in dental implantology using surgical guides produced by milling machines (Amet and Ganz 1997, Klein and Abrams 2001). Guided technology has improved together with development of related surgical techniques. An accelerated change in the paradigm can be observed. The possibility to reduce the size of flaps or even performing flapless surgery appears to be a plausible treatment modality for implant placement, demonstrating both efficacy and clinical effectiveness (Bordala 2009). Having a detailed knowledge from the anatomy before operation and the capability of precise planning and the usage of image guided systems, bone grafting can be avoided in many cases (Fortin 2009). The correct use of imaging and guided systems makes implant placement less invasive and treatment outcome more predictable (Bornstein et al 2014, Tahmaseb et al 2014). 


\section{Aim of the Studies:}

Several in vitro and in vivo studies were made to evaluate the accuracy of CBCT based surgical planning. The material and methods of these studies are mainly focusing on the surgical techniques and the result are differencing in a wide spectrum. Computerized treatment planning is an exceptionally interdisciplinary area of imaging, computer science, engineering and medicine. Therefore the following hypotheses were investigated:

1. Does the resolution of imaging have an effect on the accuracy of a three-dimensional model used for surgical planning?

2. Do the further digital imaging steps have an effect on the accuracy of a model?

3. How accurate is an orthognathic surgery planned virtually?

4. Is improving accuracy of the post-operative outcome possible?

5. Implementing the experiences in guided implantology.

6. A method and system for designing and manufacturing surgical guides. 


\section{Material and Methods}

The following three chapters are logically built together as the essential approach of the thesis. Therefor they are having the „Aims and Introduction”, „Material and Methods”, „Results” and „Conclusions” parts separately. The three chapters are then discussed together in details.

\section{THE DIGITAL BACKGROUND}

a. Aims and Introduction

The aim of this chapter is to understand the basis of imaging needed for computerized treatment planning. What are the image processing steps from capturing a scan to having a fine and seemingly accurate three-dimensional model on the computer screen?

Surgical planning in the field of orthognathic surgery and guided implantology requires models of dental occlusion in previously impossible levels of precision and accuracy. Dental occlusion have been chosen to show the imaging steps on, since it is not only the most complex structures of the oral cavity but has a key role in computerized planning (Smith 1991, Ogawa et al 2000, Watamoto et al 2008, Kacobs 2011, Paquette 2011).

b. The accuracy of three-dimensional model generation. What makes it accurate to be used for surgical planning?

Advanced imaging techniques, software and computerized manufacturing techniques have made three-dimensional (3D) computer models available not only for research and development, but also for routine clinical applications (Trefny et al 2005, Schutyser et al 2005, Marchetti et al 2006). They could potentially replace classical plaster models allowing new options for occlusal analysis and treatment workflows (Favero et al 2009, Swennen et al 2009, Plooij et al 2010). The generation of a virtual model requires imaging and subsequent image processing steps. Image capture is performed by scanning of the patient's occlusion directly or of a plaster cast using either tomographic imaging modalities or optical surface scanning. The image data is then computed to produce a $3 \mathrm{D}$ visualization. 
Computed Tomography (CT) or Cone Beam Computed Tomography (CBCT) imaging captures a consecutive series of $2 \mathrm{D}$ images, containing digitized tissue densities of the scanned slice. The data stack is stored as single image slices in DICOM format (Digital Imaging and Communication in Medicine) (Hounsfield 1980, Jahne 1991, Pratt 1991, Loubele et al 2006, De Vos et al 2009).

Optical surface scanning captures 3D surface information via generation of a point cloud, rather than the interpolation of tissue densities. These points are extrapolated to a 3D surface mesh to form the shape of an object (Moerenhout et al 2009). In contrast to CT or CBCT, optical scanning only captures surface contours, without any subsurface detail. In both X-ray based imaging and optical surface scanning the final result is a 3D surface mesh of the imaged structure. The surface meshes can be than merged together to create a composite skull model (Gateno et al 2003, Noh et al 2011). This technique relies on both the accuracy of the models and the precision of the incorporation procedures.

When considering a virtual model, the clinician must be aware of the need for adequate source imaging and the image processing steps required to create the final model. Some of these steps are performed by user interaction while some are "hidden" procedures within the software. The impact of the image processing steps may subtly influence the accuracy of the final model. $G$ The generation of a virtual model from either 2D or 3D data is based on well-established imaging and image processing techniques. However, models of dental occlusion demands previously impossible levels of precision and accuracy. Surgical planning requires models of sufficient detail to enable the virtual plan to perform well when put into reality. Inadequate models may result in misleading patient assessment, inappropriate treatment and unsatisfactory clinical outcome. Conversely, accurate virtual occlusion modeling may enable more efficient and effective workflows for patient assessment and treatment.

The objective of this chapter was to evaluate the impact of different imaging modalities and image processing steps on the accuracy of the resulting virtual occlusion model, and to identify and quantify the most critical steps to ensure accurate model generation. Further goals were to educate clinicians of the implications of these computational procedures and to discuss the clinical impact of the results. We report on the use of high resolution CBCT imaging, and on image processing parameters relevant to creating an accurate virtual model of the occlusal surface. 
c. Material and Methods

\section{Image acquisition}

A standard dental plaster model was scanned using an experimental high resolution CBCT scanner (Scanco SCANCO Medical AG Brüttisellen, Switzerland) with an isotropic image resolution of $0.082 \mathrm{~mm}$ using standard CBCT image acquisition parameters $(60 \mathrm{kVp} / 40 \mathrm{keV}$ $(900 \mu \mathrm{A}))$. The DICOM information were transferred to a desktop computer running Windows XP (Microsoft Corporation, Redmond, CA) and post-processed in Amira ${ }^{\circledR}$, a commercial software package for image visualization and data analysis (Visage Imaging $\mathrm{GmbH}$, Berlin, Germany), and Geomagic Studio ${ }^{\circledR}$, a reverse engineering software package (Geomagic U.S. Corp., Research Triangle Park, USA).

\section{Image processing and analysis}

The workflow for creating a virtual model was evaluated using the CBCT data and divided into six major image processing steps. The first three steps, evaluating the impact of the (1) image resolution, (2) thresholding procedure, and (3) smoothing of the labeled threshold data, are performed on the 2D CT data before surface model generation as presented in Fig. 1. Then a 3D triangulated surface model was generated to evaluate the effect of (4) different model generation techniques, (5) smoothing the surface model and (6) reducing the number of triangles of the surfaces shown in Fig 1 and 2.

Step 1 - Image resolution.

A gold standard (GS) CT scan was captured with a $0.82 \mathrm{~mm}$ resolution. To simulate lower resolution $\mathrm{CT}$ acquisition, the gold standard image data stack was duplicated and down-sampled to a variety of resolutions of interest. A total of 8 down sampling procedures were used to produce the following different image resolutions: 4 copies were down-sampled in an isotropic manner to represent an image resolution of $0.1 \mathrm{~mm}$ to $0.4 \mathrm{~mm}$. A further 4 datasets were downsampled to represent non-isotropic scanning, all having the same image resolution of $0.4 \mathrm{~mm}$ in the $\mathrm{x}$ and $\mathrm{y}$ axes but varying image resolutions ranging from $0.4 \mathrm{~mm}$ to $0.8 \mathrm{~mm}$ in the $\mathrm{z}$ axis. Duplication and down sampling of the models was used to simulate the lower resolution imaging capture rather that scanning at lower resolution. Simulation eliminated the introduction of error due to malpositioning of the real-world model during repeated scanning at differing resolutions. This standardization meant that all deviations from the gold standard could be reliably attributed to image processing steps, rather than errors in acquisition. 
From each 2D image stack, an unsmoothed model was generated using the LegoSurfaceGen procedure within Amira ${ }^{\circledR}$. For each model an identical threshold window setting of 1421 6950 was chosen and the Amira's LegoSurfaceGen applied. The end result of this procedure was 8 virtual models of the same physical object generated from the source image data of varying resolution. Each model was then compared with the gold standard model using the distance map calculation and visualization procedure in Geomagic ${ }^{\circledR}$. The distance map procedure calculated the differences between the gold standard and the down sampled model. Distance mapping allows calculation of maximum and mean differences between the two models (Figure 1 A, B).

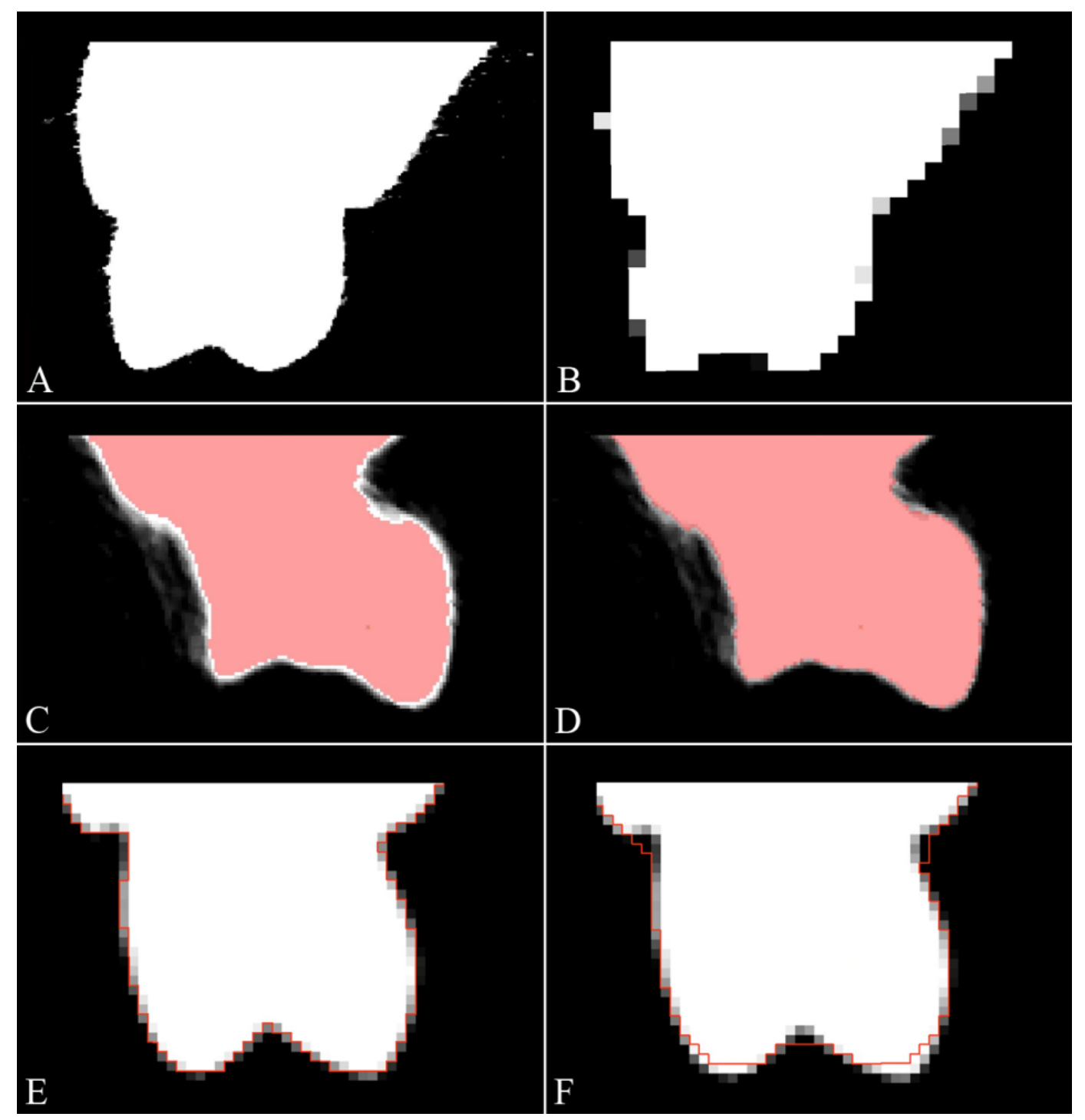

Figure 1. Image processing steps performed on $2 D C T$ data. The first line shows the impact of image resolution (A: $0.1 \mathrm{~mm}$ voxel size, B: $0.8 \mathrm{~mm}$ non isotropic). Second line highlights the threshold segmentation (C: high, exclusive-, and D: low, inclusive settings, Resolution: $0.1 \mathrm{~mm}$ ). Third line demonstrates the smoothing procedure (E: without smoothing, F: smoothed border line, Resolution: 0.3mm) 
Step 2 - Threshold segmentation.

This procedure is used to convert the continuous greyscale 2D CT data into a binary representation of which pixels of CT data represent the surface of the model being generated. A low (inclusive) threshold value of 990-6950 and a high (exclusive) one of 1914-6950 were defined. For each of the varying resolution CT scans generated in step 1, two additional models were generated using a high and low threshold and the LegoSurfaceGen procedure. For each resolution, the high and low threshold models were separately compared with the medium threshold model of the identical resolution generated in step 1. This enables the assessment of the impact of the threshold procedure, without the influence of image resolution. The deviations between the models were calculated using Geomagic's distance map calculation and visualization (Figure $1 \mathrm{C}, \mathrm{D})$.

Step 3 - Smoothing 2D CT data.

A predefined smoothing procedure was applied to the 2D CT data using the 'smooth label' function (Parameters: size 5) in the Amira segmentation editor. A LegoSurfaceGen model was created from each of the smoothed 2D CT datasets. The deviations between the models were compared with the models of corresponding resolution obtained in step 1, using Geomagic's distance map calculation and visualization (Figure 1 E, F).

Step 4 - 3D model generation using the Marching Cube Algorithm.

For each of the resolutions established in step 1, a model was created using Amira's standard SurfaceGen module, rather than LegoSurfaceGen. The SurfaceGen procedure creates meshed surface models according to the Marching cubes algorithm, smoothing the voxel structure into a triangulated meshed surface topology. The deviations between the SurfaceGen model and the identical resolution LegoSurfaceGen models obtained in step 1 were compared using Geomagic's distance map calculation and visualization (Figure 2 A, B). 


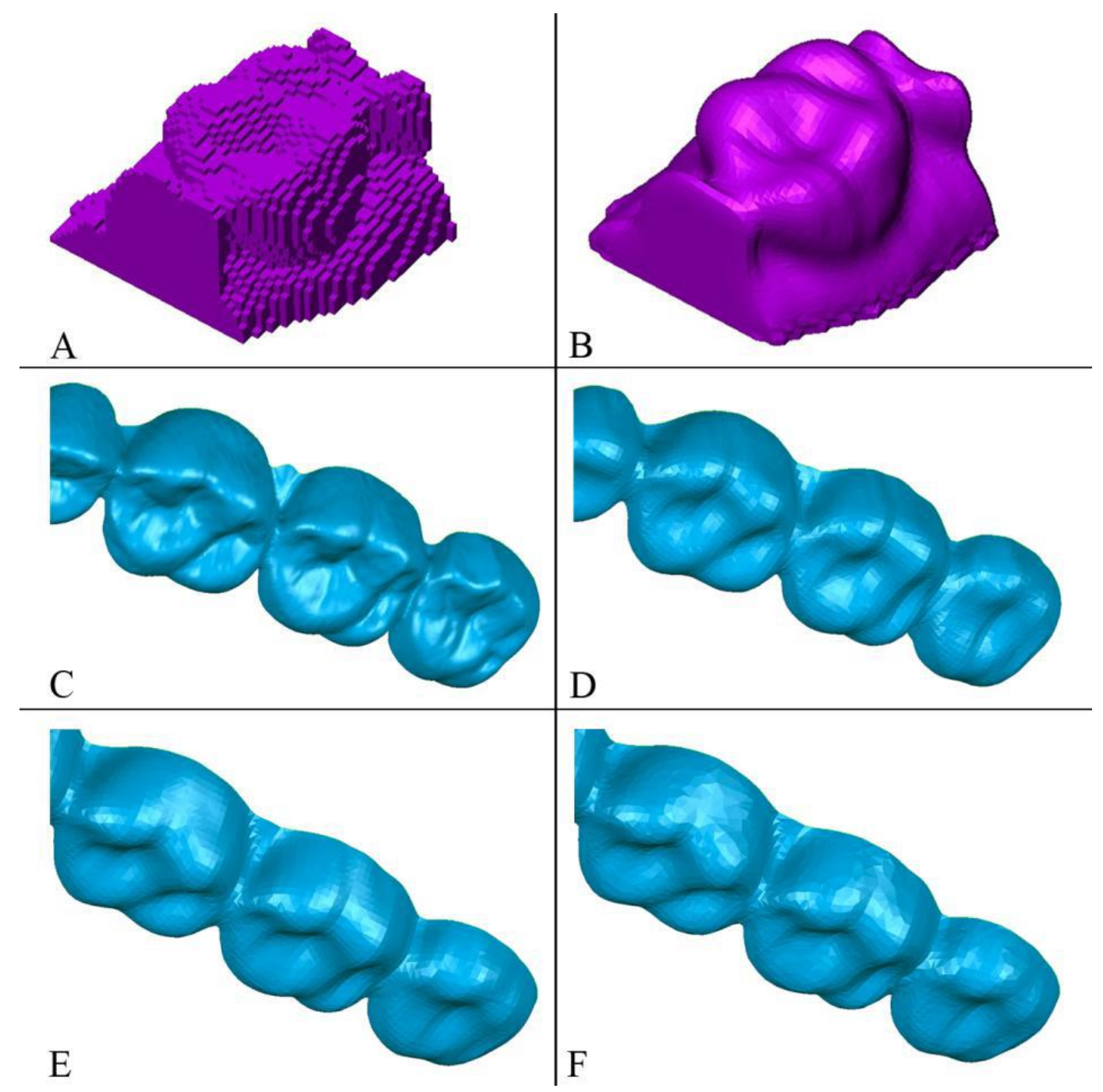

Figure 2. The effects of image processing steps made on 3D data. First line shows the effect of 3D model generation from 2D data with different algorithms (A: LegoSurfaceGen, B: Marching Cubes Algorithm, Resolution: 0.4mm) Effects of smoothing the 3D surface is visualized in the second line (C: moderate-, D: extensive smoothing, Resolution: 0.3mm) Third line presents the result of reducing the number of the surface triangles (E: 41000 triangles, F: 20500 triangles, Resolution 0.4mm)

Step 5 - Smoothing of generated 3D models.

Two different smoothing settings were chosen in Geomagic for each model obtained in step 4: Setting 1 corresponding to moderate smoothing ("smoothness level" to a low level "3" and "Curvature priority" to a high level " 8 ") and setting 2 corresponding to extensive smoothing ("smoothness level" to a high level " 8 " and "Curvature priority" to a low level "3"). For each resolution, the models with moderate and extensive smoothing were separately compared with the original unsmoothed model of identical resolution generated in step 4. The differences 
between models were analyzed using Geomagic's distance map calculation and visualization (Figure $2 \mathrm{C}, \mathrm{D})$.

Step 6 - Reducing the number of the mesh triangles.

In the eight surface models generated in step 4 the number of the mesh triangles were calculated in Geomagic. The number of triangles for each model were reduced by $50 \%$ to represent a common complexity reduction procedure performed in model generation workflows. For each resolution, the resulting simplified model was compared with the identical resolution model obtained in assessment 4. The differences between models were analyzed using Geomagic's distance map calculation and visualization (Figure 2 E, F).

d. Results:

The impact of CT scan resolution and the 5 subsequent workflow steps were assessed (Figure $3)$.

\section{Resolution}

Beginning with the highest resolution, the data revealed a linear increase in the deviations between the models generated from reduced resolution CT scans and the gold standard model. In the non-isotropic image resolution part (i.e. from 0.5 to $0.8 \mathrm{~mm}$ ) there was a less steep slope, compared to the isotropic part. For each image resolution, the max $+/ m a x-$ values showed similar absolute deviation values. Between the highest and lowest resolution, there was a fourfold increase of the deviation, with maximum absolute values of about $0.45 \mathrm{~mm}$ (corresponding to $+0.438 /-0.492 \mathrm{~mm}$ ). The distance maps demonstrated a uniform deviation pattern on the occlusal surfaces, when compared with the GS (Figure 3, Step 1).

2a. Threshold segmentation with low threshold value

The data showed the maximum deviation in the positive direction from the corresponding resolution GS (CGS) increased as CT resolution decreased in models with isotropic voxels, and did not change in models with non-isotropic voxels. The max+ and max- values showed different absolute values. The max- values showed an approximately linear increase up to $0.8 \mathrm{~mm}$, regardless of model isotropy. The max+ values showed as similar increase from 0.1 to $0.4 \mathrm{~mm}$, but afterwards the values remained virtually unchanged, between the $0.4,0.5,0.6,0.7$ and $0.8 \mathrm{~mm}$ resolution $\mathrm{CT}$ scans. 
2b. Threshold segmentation with high threshold value

The data illustrated the maximum deviations from the CGS in the positive directions increasing linearly as CT resolution was decreased. The maximum negative deviation increased with decreasing resolution in the models with isotropic voxels, but did not change significantly with the non-isotropic voxels. This is the inverse of the results described in section $2 \mathrm{a}$. The max+ exhibits a linear increase up to $0.8 \mathrm{mmm}$ and the max- values remained stable at resolutions above $0.4 \mathrm{~mm}$.

In both assessment $2 \mathrm{a}$ and $2 \mathrm{~b}$, the distance maps show a uniform deviation pattern within the overall occlusal surface, when compared with the CGS.

\section{Smoothing 2D CT data}

The data displayed a linear increase in model deviation as CT resolution was reduced. In contrast to assessment (1), (2a) and (2b) this smoothing procedure lead to a characteristic change in the surface topology of the occlusal surface with loss of areas with small-radius curvatures. The loss of details in area of tight curvature lead to a flattening of the occlusal cusps (thus reducing the height of the occlusal cusps) and of the occlusal fissures (thus filling the occlusal fissures), leading to an overall flattening of the occlusal surface topology as shown on the distance maps in Figure 4.
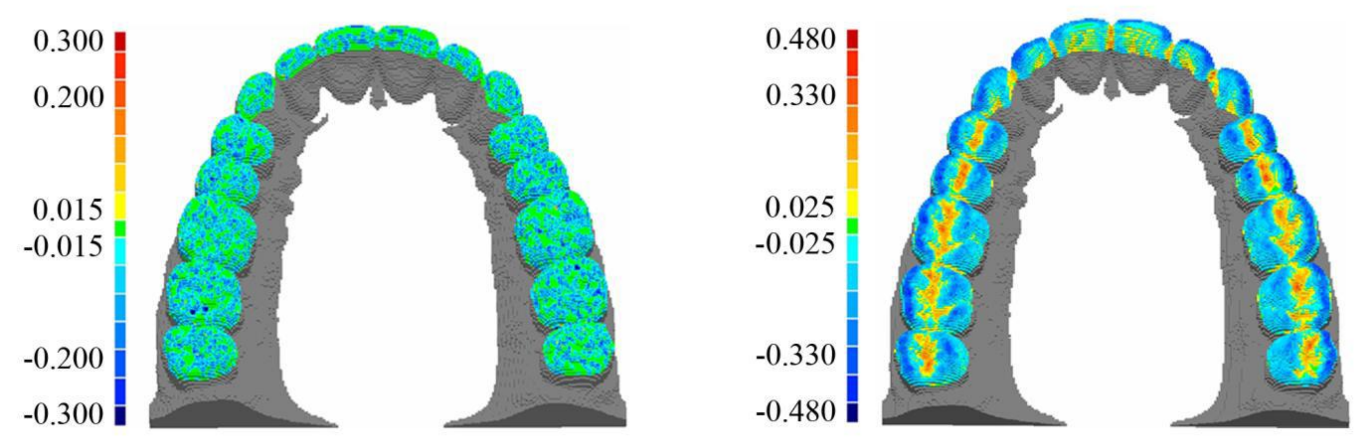

Figure 4. Distance maps showing the different surface topology modifications. Uniform deviation pattern on the occlusial surface on the left side (Step 2a), and overall flattening the surface with filling the fissures and cutting the cusps on the right side (Step 3). 
4. Model generation using the Marching Cubes algorithm

Among both for the max+ and max-values, there was a linear increase in deviation from the CGS until $0.4 \mathrm{~mm}$ image resolution. The rate of deviation accelerated at lower resolutions than $0.4 \mathrm{~mm}$. Large deviations were observed for values at a non-isotropic image resolution of 0.7 and $0.8 \mathrm{~mm}$, deviating $>1.6 \mathrm{~mm}$ from the CGS. The Marching Cubes Algorithm resulted in a similar non-uniform change in the surface topology, as observed in (3).

5a. Smoothing on generated surface models with moderate settings

The data demonstrated linear growth in deviation until the $0.4 \mathrm{~mm}$ resolution group, and then ceased to change. This procedure did not change the max values. Maximum deviations approached $0.12 \mathrm{~mm}$.

5b. Smoothing on generated surface models with extensive settings

The data displayed growth in deviation. In contrast to $5 \mathrm{a}$, when using these settings the max+ increased with lower image resolution. At the non-isotropic level of 0.7 and 0.8 the max+ deviation reached up to $1.6 \mathrm{~mm}$.

6. Reducing the number of the triangles

Reducing the triangle number by $50 \%$ did not change the max+ deviations. Below a CT resolution of $0.3 \mathrm{~mm}$, the reduction in model complexity lead to deviations by between 0.1 and $0.2 \mathrm{~mm}$. 

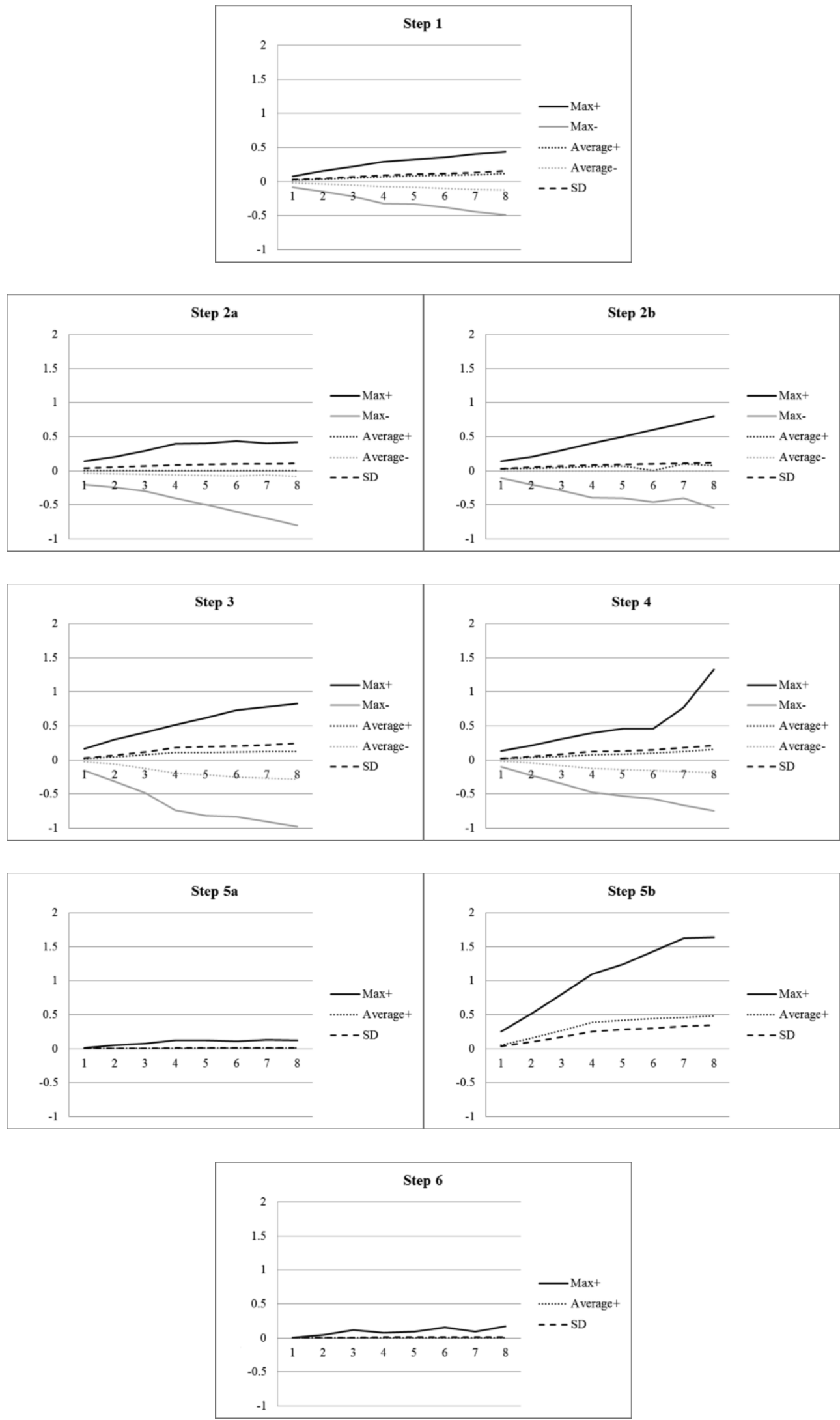

Figure 3. Deviations visualized in each step with their corresponding resolution. Resolution in " $x$ " axis (mm $x$ 0.1) Deviation in " $y$ ” axis ( $\mathrm{mm})$ 


\section{e. Conclusion}

The objective of this study was to assess the impact of the different imaging modalities and different image processing steps on the accuracy of a virtual occlusion model and to guide clinicians to understanding the most critical steps for accurate model generation. The following image processing steps were assessed: image resolution, manual threshold segmentation, smoothing the labeled threshold data, the Marching Cubes algorithm (Harvey et al 1987, Lorensen and Cline 1987), smoothing of the surface mesh (Belyaev 2003, Taubin 1995) and the number of meshes (Schroeder et al 1992, Garland and Heckbert 1997, Leubke 2001). Intuitively resolution is the essence of an accurate model. No image processing step can compensate for lack of resolution in the original data. Inadequate resolution amplifies the negative effects of image processing. However, image processing can severely degrade the quality of a model generated from high-resolution data. The evaluations shows that each processing step effects the quality and accuracy of the 3D model. Each step is dependent on the image processing techniques chosen in previous steps. Errors introduced early in the workflow are multiplied by subsequent image processing steps. Particularly, early decisions made during manipulation of label field data in 2D scans have a dramatic effect on final model accuracy.

The usage of virtual 3D models for treatment planning and computer aided surgery (CAS) systems has several advantages. Virtual treatment planning can make surgeries less invasive, operating time shorter and post-operative outcome more accurate. This technique relies on the accuracy of the virtual model to ensure a successful surgery. Models produced from highresolution source data can appear accurate on superficial inspection, despite key inaccuracies introduced by image processing. Clinicians planning surgery with virtual models must be familiar with each step of the workflow. The production of accurate 3D models from imaging data requires specific knowledge of the techniques involved.

The study demonstrates that there are two distinct classes of errors introduced by image processing. One class makes uniform change to the entire occlusal surface, making it smaller or bigger. The other alters the surface topology in a non-uniform manner, particularly impacting areas of high geometric complexity. Both effects lead to inaccuracies in virtual model generation. 
A potentially satisfactory alternative to 3D model generation from CT data is optical scanning of dental structures. Use of this technique does not escape the need for CT in many cases, nor does it eliminate accuracies from 3D model image processing. If detail of the underlying structures is needed for surgical planning, CT scanning is still required, as is often the case in orthognatic and surgical procedures affecting dental structures. An additional source of error within optical scanning is the merging and alignment of CT-derived and optical scan-derived model data. Finally, models generated from optical surface scanning must still undergo image processing of the 3D model, potentially introducing the inaccuracies detailed in this study.

In conclusion, accurate 3D models require a combination of appropriate resolution imaging and image processing. The importance of resolution in the source imaging is well understood by surgeons. The critical nature of image processing is poorly recognized and this study demonstrates it as a source of significant error. Adequate quality models can be produced using average resolution CT scanners as long as the importance of image processing is understood. The operator must understand the implications of each step of the model creation workflow to ensure their model truly reflects reality. 


\section{TRANSFORMING THE DIGITAL PLAN TO REALITY}

\section{f. Aims and Introduction}

The accuracy of clinical orthognathic cases will be shown as a preliminary study.

The aim of this chapter is to create accurate three-dimensional models for planning a clinical case with the knowledge gained previously. The usage of high-end technologies such as planning software, surgical wafers manufactured with three-dimensional printers and evaluation software are also part of this case report and technical note.

\section{g. Evaluation of the Accuracy of Ten Clinical Orthognathic Cases}

Traditional planning of orthognathic surgeries based on two dimensional imaging requires strong imagination of the structures in their three dimensional positions. The need of many precise data transfers between surgeon, orthodontist and technician makes planning unpredictable and time consuming. Recent advances of both image acquisition systems and 3D virtual planning softwares made a breakthrough in visualizing and planning these complex facial deformities.

The aim of this preliminary study is to compare the pre-operative plan with the post-operative result from ten orthognathic cases. The deviations are showing the accuracy of the surgeries visualized on deviation maps.

\section{Material and Methods}

The CBCT data of ten already treated orthognathic cases were randomly chosen into this preliminary study. All the cases were scanned, planned and operated in the same institute (Cranio Facial Center, Hirslanden Klinik, Aarau, Switzerland). The cases were planned in a commercially available treatment planning software and then the surgeries were performed with intermediate splints manufactured with a three-dimensional printer according to the plan. Each patient folder contained the following data: (1) pre-operative CBCT scan from the skull (2) the plan of the osteotomized segment (ROI) in the same coordinate system with the pre-operative data (3) post-operative CBCT scan from the skull. 
The digital evaluation of the cases were performed in the AO Research Institute, Davos, Switzerland. Three-dimensional models were made from each datasets. Data (3) was transferred to data (1) and (2). Data (3) was aligned to data (1) through non-moving anatomical landmarks. With this alignment the post-operative model of the plan (3) got in the identical coordinate system with the model of the osteotomized segment (2). Point to point distance calculation was made between the two models and visualized on the ROI with a distance map. Mean and standard deviations were calculated in all ten cases.

\section{Results}

The evaluation showed a mean deviation between the pre-operative plan and the post-operative outcome of 3,94 $\mathrm{mm}$ with a standard deviation of $1,26 \mathrm{~mm}$. Distance map visualization is shown in Figure 5 and numeric results from the ten cases are displayed in Table 1.

\begin{tabular}{|c|c|}
\hline Patient ID & Maximal Deviation $(\mathrm{mm})$ \\
\hline 1 & 3,0 \\
\hline 2 & 4,9 \\
\hline 3 & 2,6 \\
\hline 4 & 3,8 \\
\hline 5 & 4,0 \\
\hline 6 & 5,6 \\
\hline 7 & 3,3 \\
\hline 8 & 6,3 \\
\hline 9 & 2,9 \\
\hline 10 & 3,0 \\
\hline
\end{tabular}

Table 1. Maximal deviations of the ten cases 

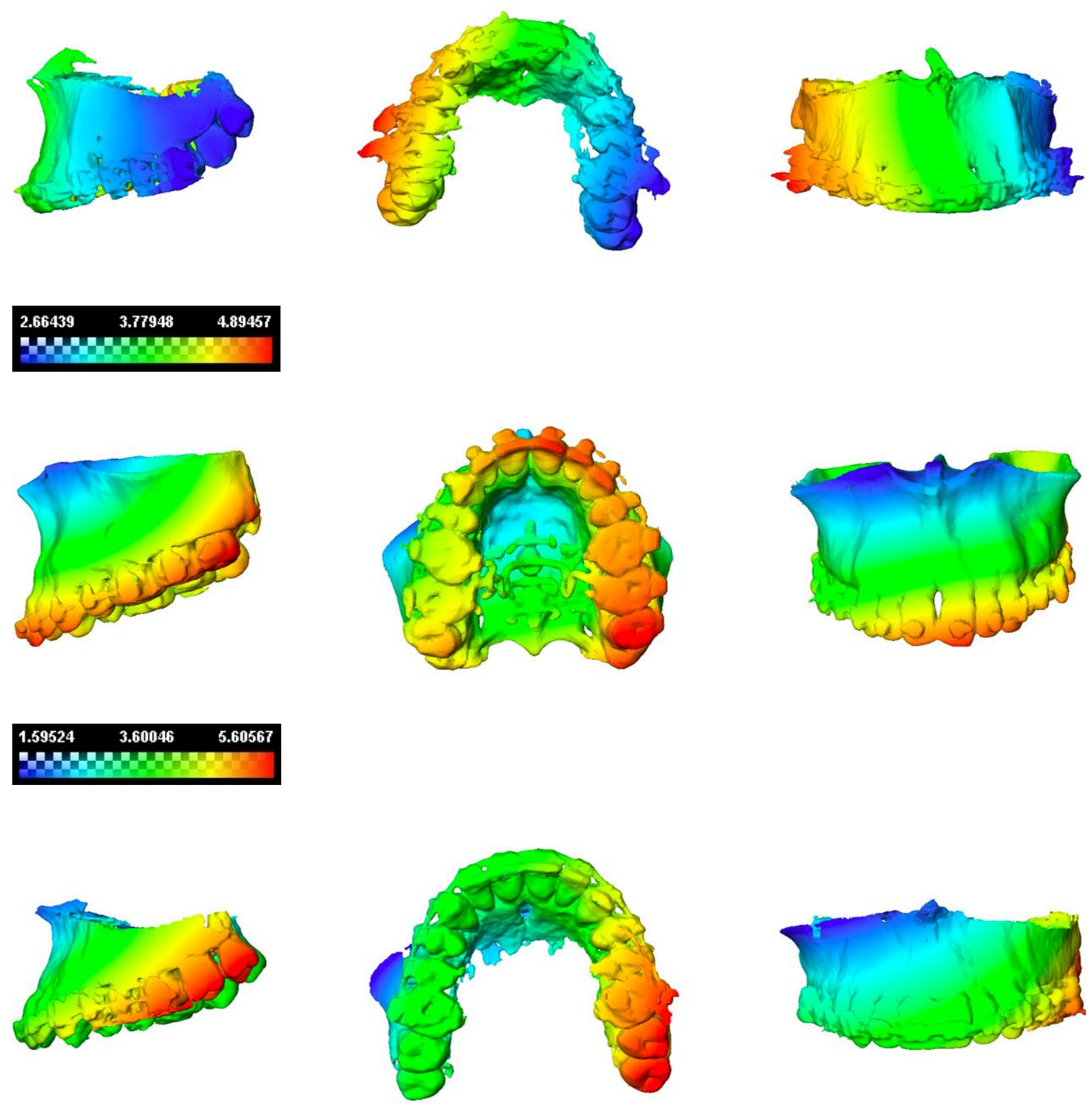

Figure 5. Evaluation shown on distance map

\section{Conclusion}

Despite the high resolution CBCT scans, the 3D planning and the individual rapid-prototyped splints, the deviations between the pre-operative plans and the post-operative results are considerable in most of the cases. Utilizing the knowledge gained in imaging and image processing might increase accuracy in the 3D models, therefore the post-operative results. 
h. Correction of a Severe Facial Asymmetry with Computerized Planning and with the Use of a Rapid Prototyped Surgical Template: a Case Report / Technique Article

Correction of severe facial asymmetry is a challenging task due to the geometric complexity of the dentition, the bony structures and the soft tissues. Mandibular asymmetry is usually associated with a unilateral vertical maxillary excess and an occlusal cant, therefore, in most cases the deformity cannot be treated with single-jaw surgery (Cheong and Lo 2011).

Traditional cephalometric analysis is of limited value in interpreting the cause of the asymmetry, because complex three-dimensional (3D) structures are projected onto two dimensional (2D) planes. Treatment planning of an asymmetric case requires three-dimensional consideration in the sagittal, coronal and horizontal planes. Traditionally, manual model surgery is an essential part of the preoperative workup that involves many time-consuming laboratory based steps. When two-jaw surgery is performed, following the transposition of the maxilla on the stone dental model in the articulator an inter-occlusal splint is fabricated that serves as an intermediate guide for repositioning the maxilla relative to the intact mandible. The second, or final wafer relates the mobilized mandible to the fixated maxilla.

It is of critical importance that model surgery is based on accurate translation of the theoretical transposition data. Any discrepancy between the plan and the model surgery will lead to an inaccurate inter-occlusal splint. A poorly designed and/or fabricated wafer can lead to a disastrous outcome even when the most skilful surgical technique is used.

If a symmetric or slightly asymmetric face is operated on, when the jaws are moved mainly in the antero-posterior and vertical direction, traditional, 2D analysis and planning are usually satisfactory. But even in these cases, small errors in each step of model surgery can compound and lead to an inaccurate result (Ellis 1990, Choi et al 2009, Cevidanes et al 2010).

Major asymmetry involving both the upper and lower jaws often requires complicated two-jaw surgery. In these cases 3D planning is essential. The problem is twofold: first, how the most precise planning can be achieved and second, how the treatment plan can be transferred to the operating room. Accurate cephalometric analyses and 3D planning based on plain lateral and frontal cephalogram are often not possible (Edler et al 2004, Hwang et al 2006, Gateno et al 2011).

Improved imaging techniques and advances in software engineering have moved 3D computer models from the research and development area into routine clinical application (Baek et al 2006, Swennen et al 2009, Hsu et al 2013). Three-dimensional reconstruction images can be easily rotated and viewed from any angle. Accurate measurements can be performed on the 
maxillofacial complex and this helps not only to understand the ethology of facial asymmetry but to plan the osteotomies and movements of the segments.

Rapid prototyping is a remarkable, quickly evolving technology that has been revolutionizing the manufacturing process in several fields. With these technologies splints can be made that can guarantee the precise repositioning of the bony segments during surgery (Metzger et al 2008, Levine et al 2012).

The aim of this study is twofold, first, to investigate whether virtual 3D model surgery is suitable for treatment planning of an asymmetric two-jaw surgery, and second, to examine if rapid prototyping may eliminate the need for manual model surgery and the conventional fabrication of the inter-occlusal splint in the dental laboratory. A case of a severe facial asymmetry is reported when computer aided surgical planning was performed and the intermediate wafer was designed virtually and was manufactured by a three-dimensional printer.

Case Presentation / Technique Description

A 26-year-old male complained of facial asymmetry and eating difficulties. Clinical evaluation revealed severe right-sided hemi mandibular elongation with small compensatory transverse canting of the maxillary occlusal plane (Figure 6). 

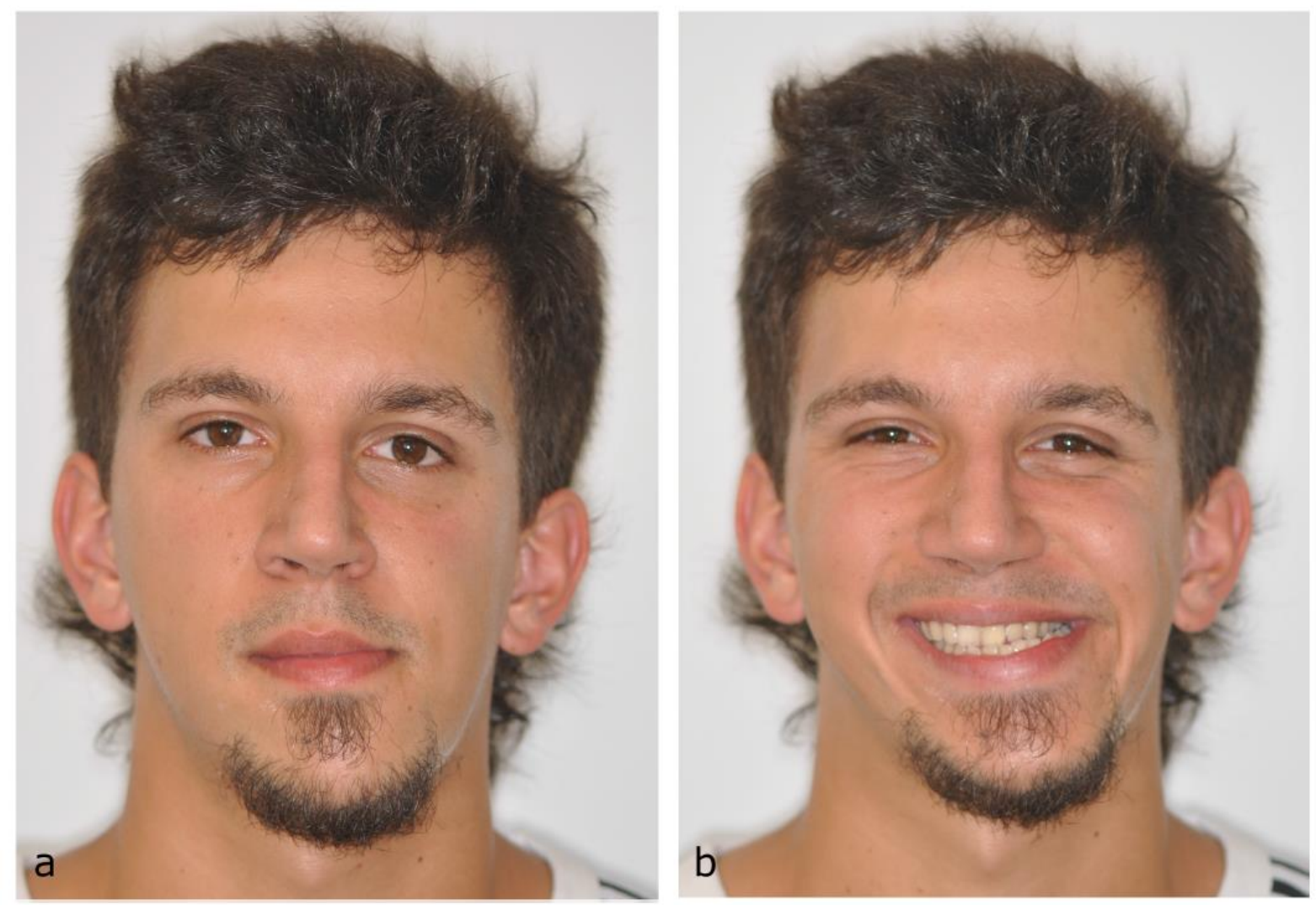

Figure 6. (a) Initial facial view. (b) Initial facial smiling

Cross bite was observed on the left side. In the sagittal plane Class III malocclusion was noted on the right side while Class I molar and canine relationship was found on the left side. The mandibular front teeth, the left sided premolars and molars were lingually inclined. The maxillary midline was coincident with the facial midline. The mandibular dental midline and the mentum deviated to the left 11.8 and $15 \mathrm{~mm}$, respectively (Figure 6,7,8). There was mild crowding in both arches. Technetium isotope failed to show increased uptake in the condylar regions.

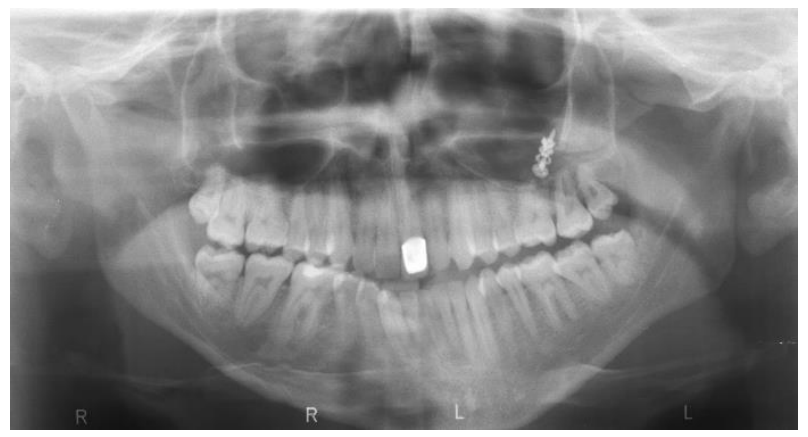

Figure 6. Initial panoramic radiograph 


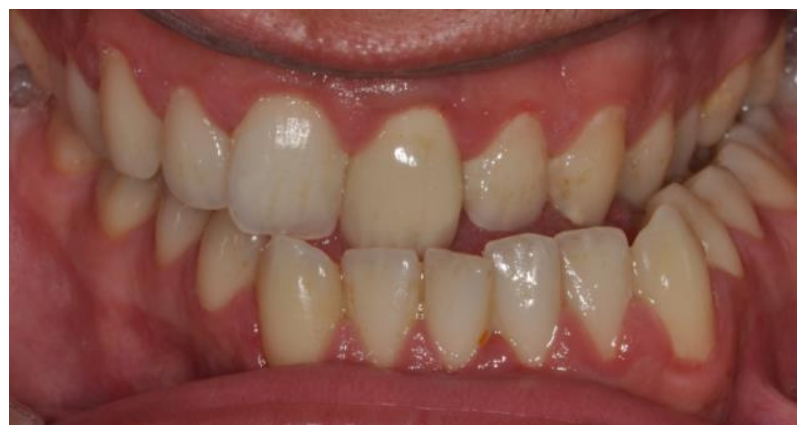

Figure 7. Pre-operative intraoral photograph

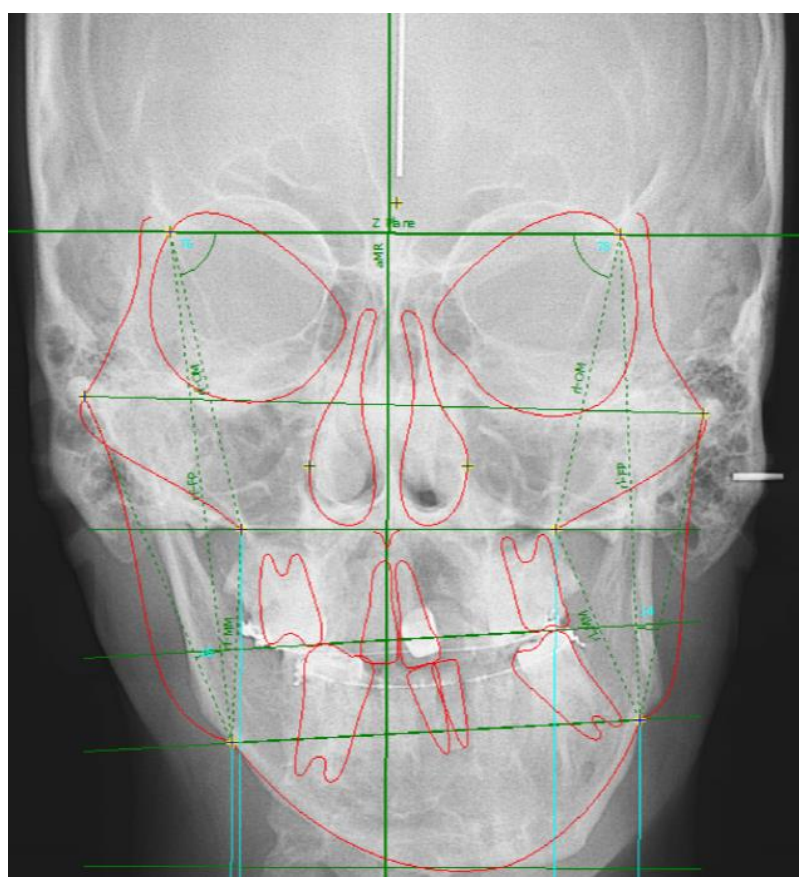

Figure 8. Pre-surgery frontal cephalometric $x$-ray shows the compensatory transverse canting of the maxillary occlusal plane

Preoperative orthodontic treatment lasted for 18 months and consisted of alignment and elimination of the transverse and sagittal dental compensation and arch coordination. After pre-surgical orthodontic treatment was completed, computed tomography scan was obtained with an isotropic image resolution of $0.3 \mathrm{~mm}$ and standard image acquisition parameters $(60 \mathrm{kVp} / 40 \mathrm{keV}(900 \mu \mathrm{A})$. The patient was scanned in a supine position. The gantry had a zero inclination. The digital imaging and communication in medicine (DICOM) data were directly transferred to a personal computer. An in-house developed 3D planning software (JMed software, TraumArt Ltd, University of Szeged, Hungary) was used to reformat DICOM stack images into a 3D structure and to perform virtual preoperative surgical planning (Figure 9a). Three-dimensional facial analysis was performed following the construction of the mid-sagittal, the Frankfort horizontal and the mandibular planes (Figure 9b). Maxillary height, ramus length, 
body length, body height, frontal ramal inclination and lateral ramal inclination were measured on both sides. After evaluation of the factors that contributed the chin deviation virtual surgery was performed.

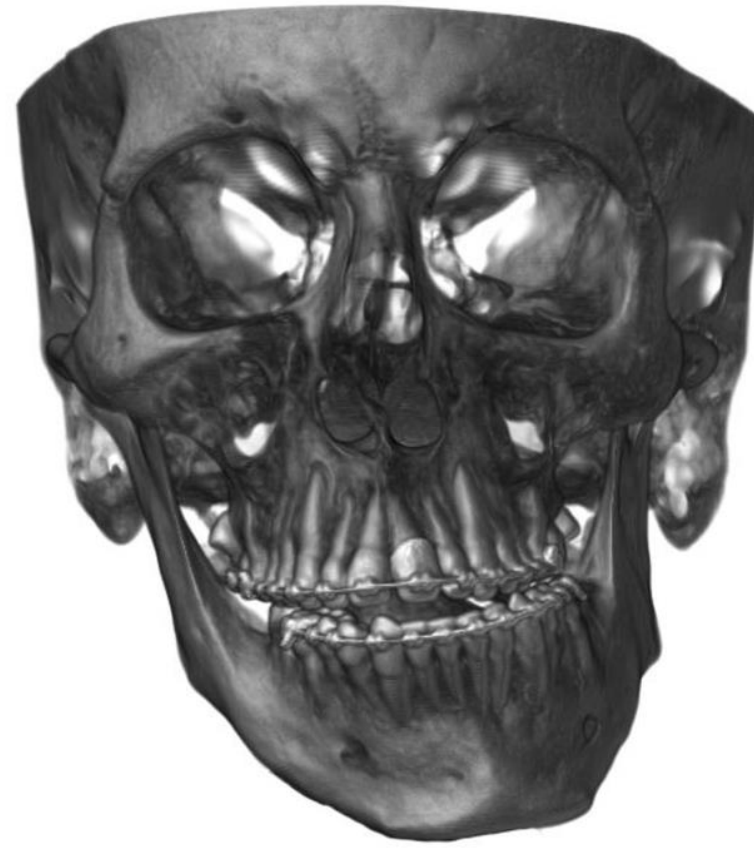

a

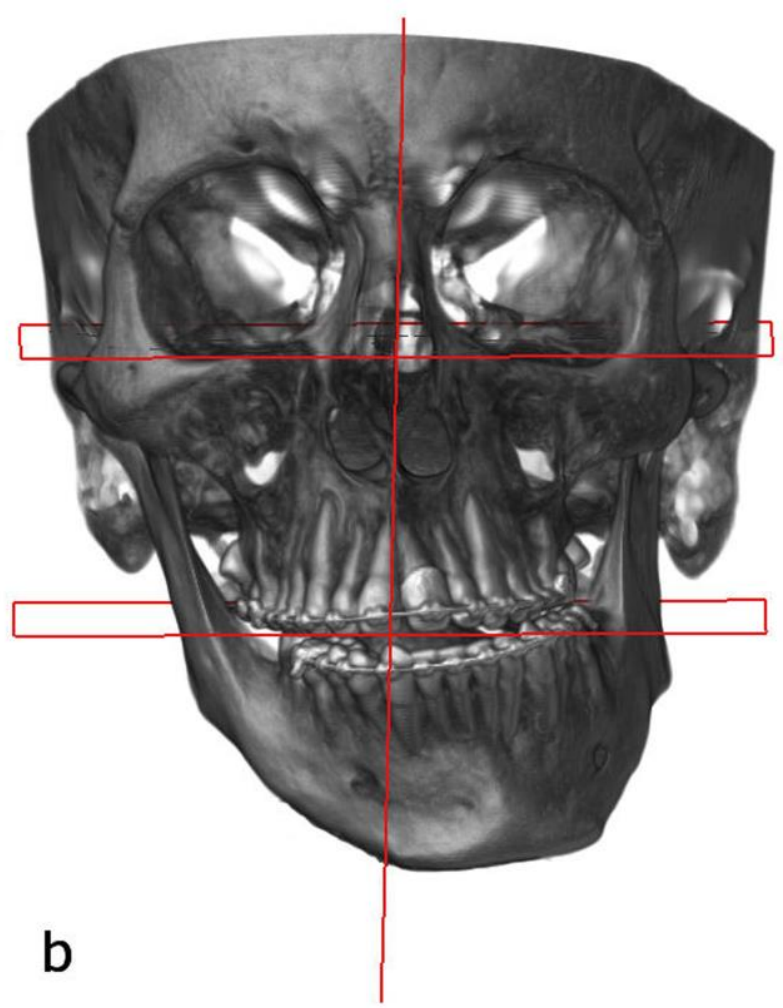

Figure 9. (a) Preoperative CT scan. (b) Reference planes defined

Selection of the bony structures was made by the software's semi-automatic segmentation tool and surface models were generated from each structure (Figure 10) (Lorensen and Cline 1987, Erdőhelyi et al 2007). Virtual conventional Le Fort I osteotomy was performed on the segmented models. The osteotomized segment was selected and was individually moved and rotated to reconstruct the symmetry of the maxilla (Figure 11).

A model of a virtual intermediate surgical wafer was created with the maxilla in the planned position and the mandible in its original place (Figure 11b). The model of the wafer was printed with a 3D printer from a bio-compatible synthetic material that is suitable for short-term mucosal membrane contact (Figure 12). The splint was checked for occlusion on the patient's lower and upper dental arches and fitted well in both cases. 


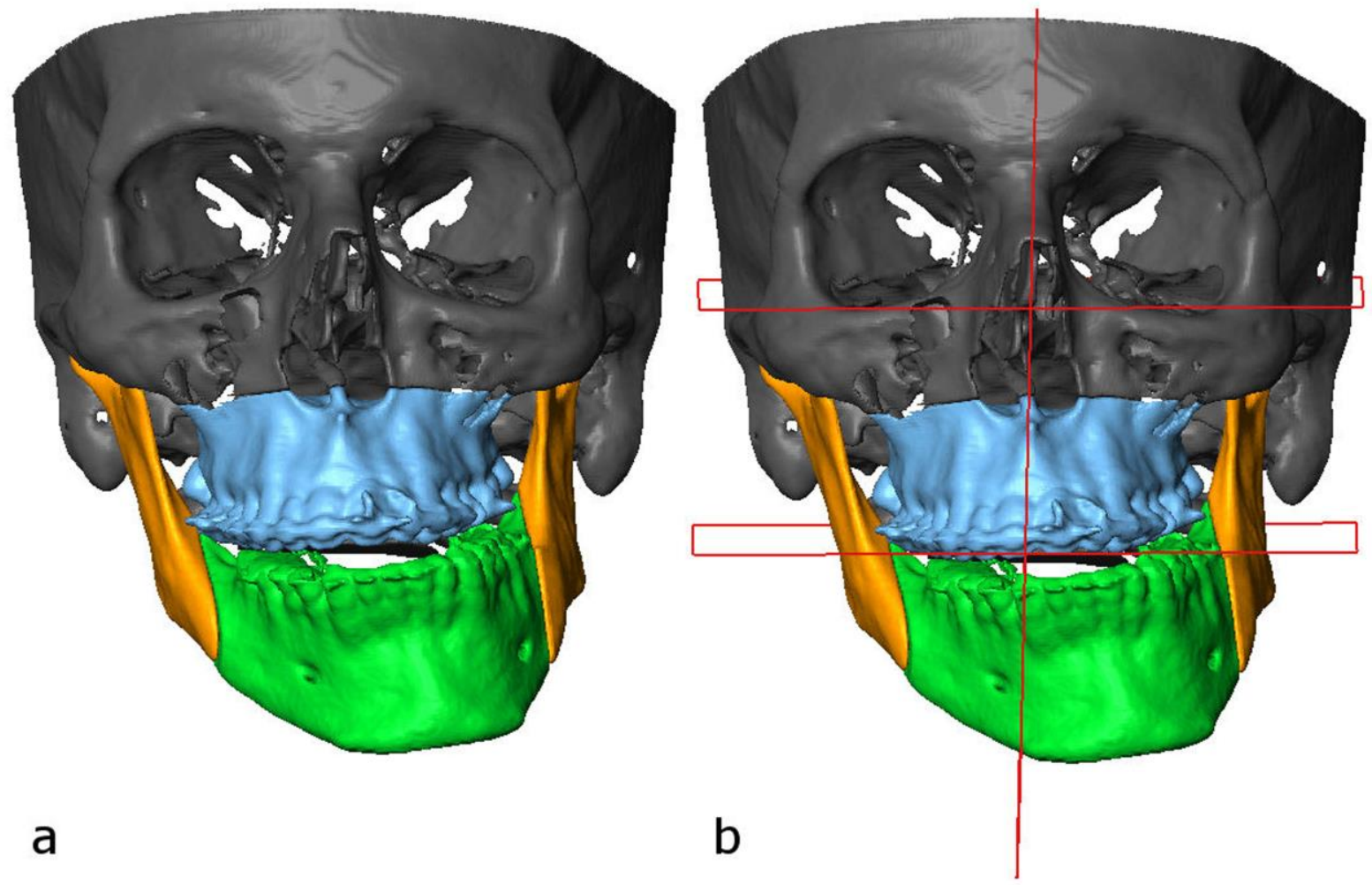

Figure 10. (a) (b) Selection of the bony structures

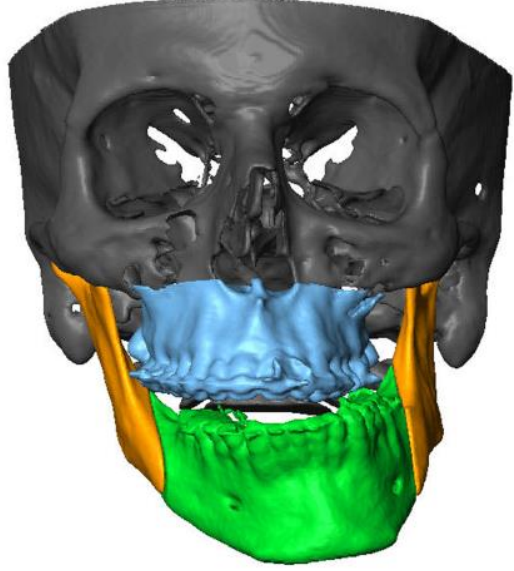

a
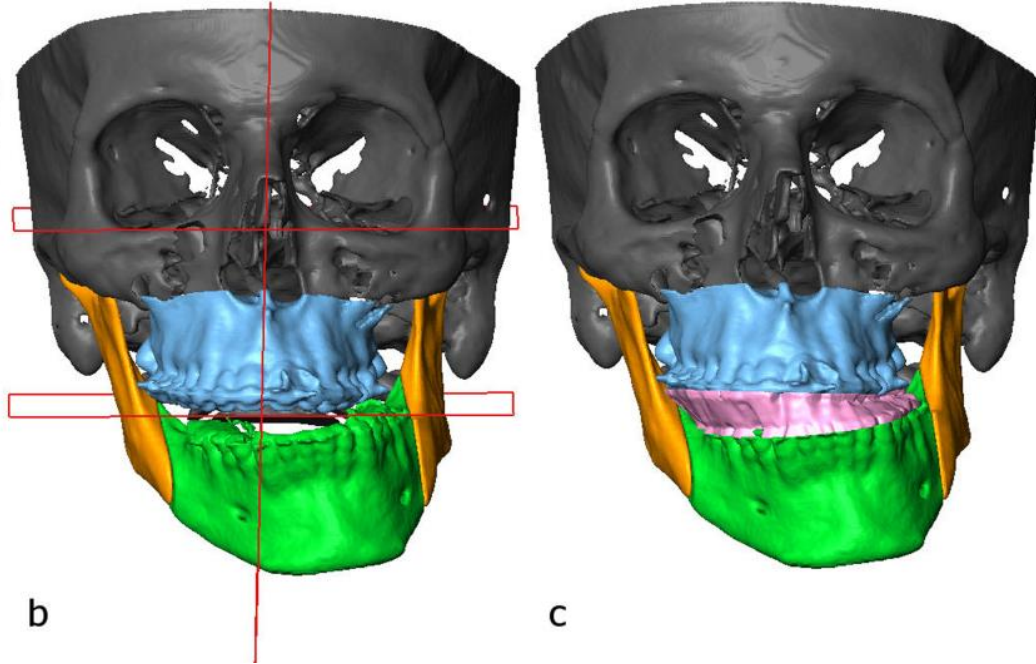

C

Figure 11. (a) (b) Virtually repositioned maxilla (c) Virtually designed intermediate wafer 


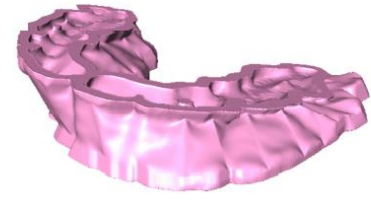

a

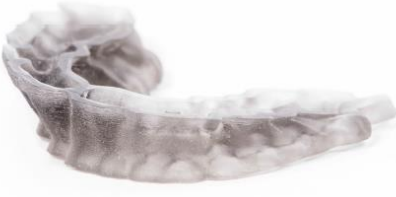

b

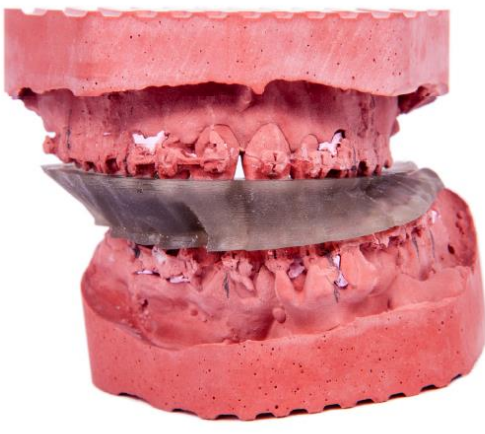

Figure 12. (a) Model of intermediate wafer (b) 3D printed intermediate wafer (c) wafer fitting on the plaster cast

Following that the mandible was rotated into the correct position with virtual bilateral sagittal split osteotomy to visualise the movements of the osteotomized segments (Figure 13).

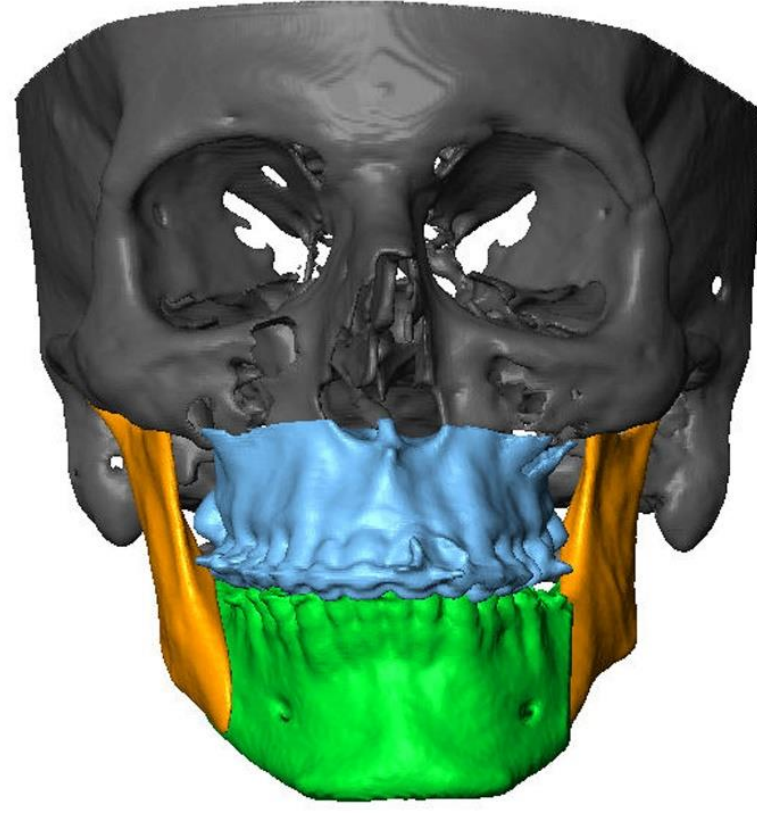

a

Figure 13. (a) (b) Virtually repositioned mandible

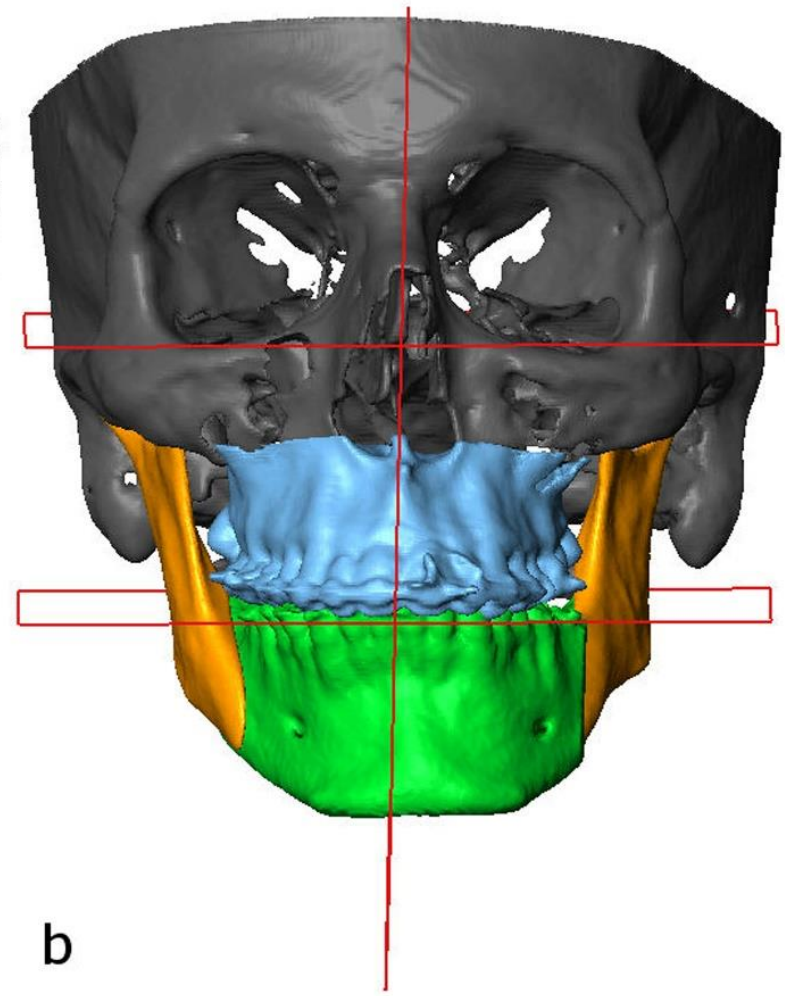

In the surgical phase Le Fort I osteotomy was carried out as planned. The mobilized maxillary segment was rotated clockwise and was repositioned by application of the virtually planned intermediate wafer and mandibulo-maxillary fixation. The virtually designated intermediate wafer fitted well during surgery (Figure 14). Miniplate fixation to the vertical facial buttresses was performed. Mandibulo-maxillary fixation was then released and the bilateral sagittal split 
mandibular osteotomies were carried out. The distal segment of the mandible was rotated to the right and placed into the desired occlusion. Final splint was not used as the teeth were in good occlusion. Osteosynthesis was performed with titanium miniplates and screws (Figure 15,16).

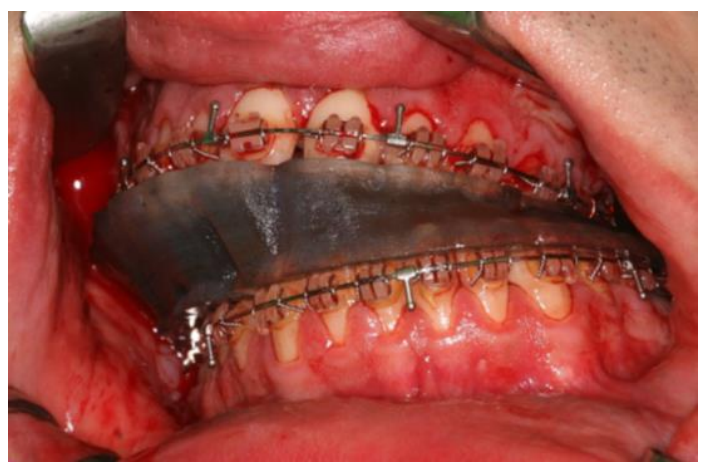

Figure 14. The intermediate wafer fits well between the maxillary and mandibular dentition during surgery

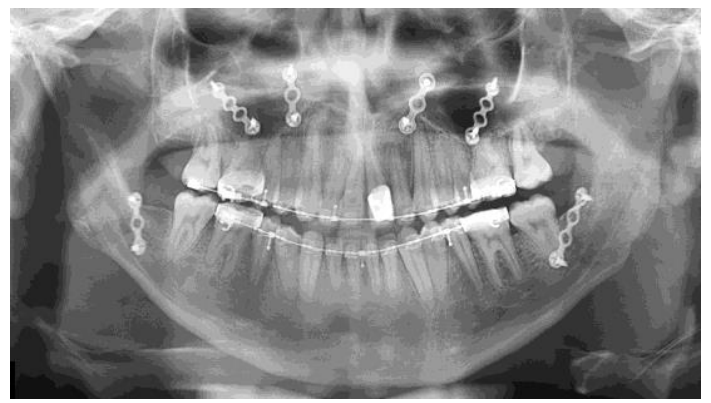

Figure 15. Panoramic radiograph after two-jaw surgery

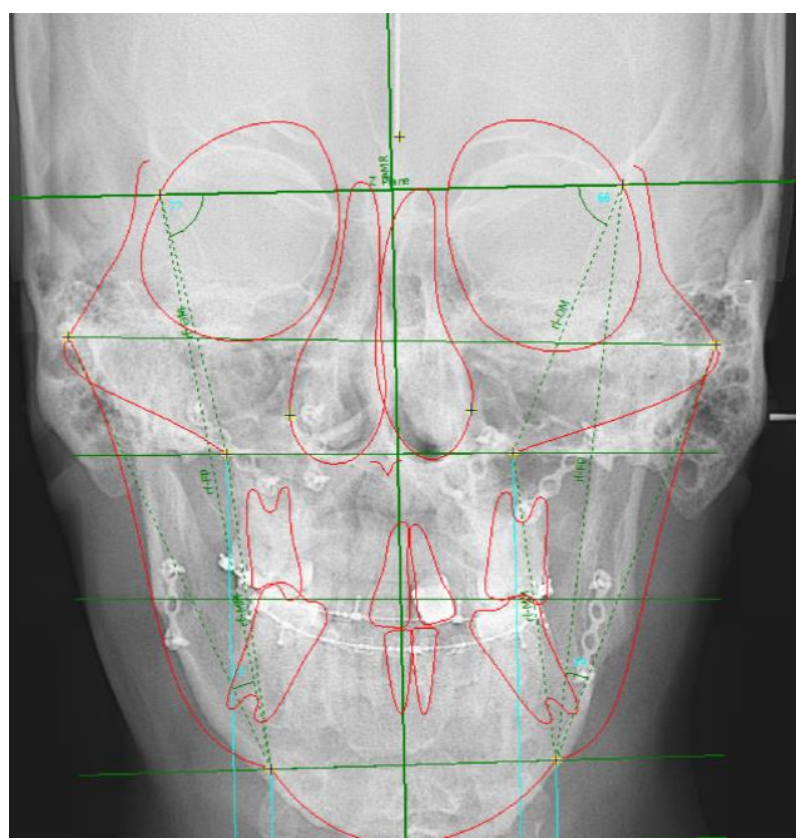

Figure 16. Postoperative frontal cephalometric $x$-ray shows that the facial symmetry has improved significantly 
Postoperative intermaxillary fixation was maintained with tight elastics for 2 weeks. Loose guidance elastics were worn for a further period of 10 weeks. Two months after the surgical procedure, orthodontic treatment was resumed. Final arch coordination and occlusal settling were accomplished during the next 6 months (Figure 17). One year after the first surgery, genioplasty was performed at the same time of the removal of the previously implanted miniplates and screws. Standard intraoperative measurements were used without templates, the chin was rotated to the left by $4 \mathrm{mms}$ (Figure 18,19).

The facial symmetry was improved significantly after the operations. The occlusion is stable and the patient is satisfied with his facial appearance. There is no sign of relapse after 18 months following the first surgical procedure (Figure 20).

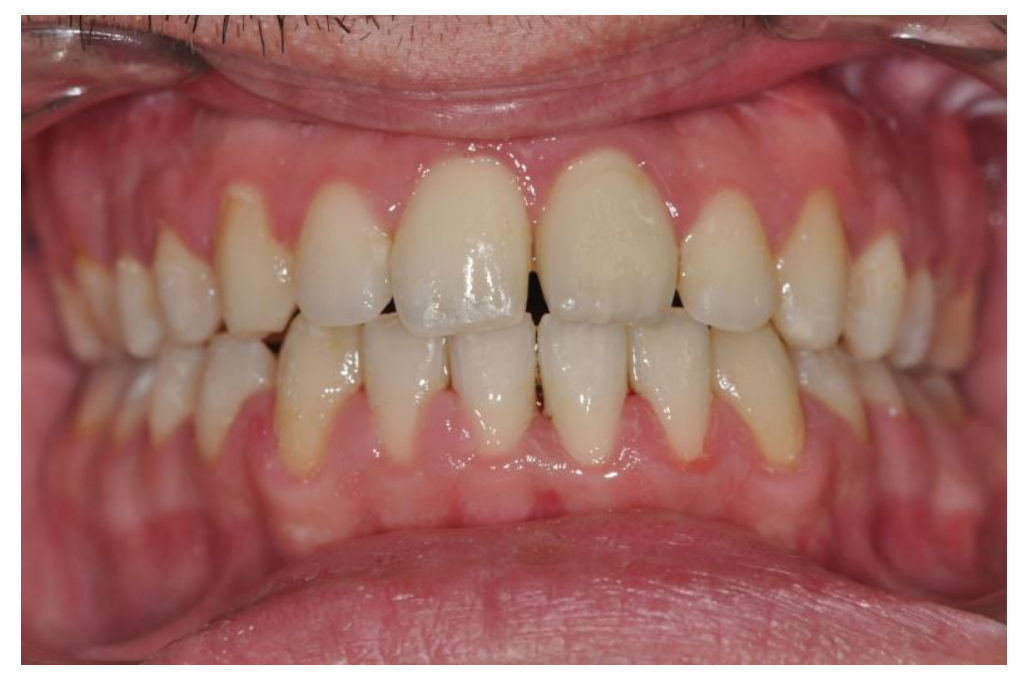

Figure 17. Final intraoral photograph

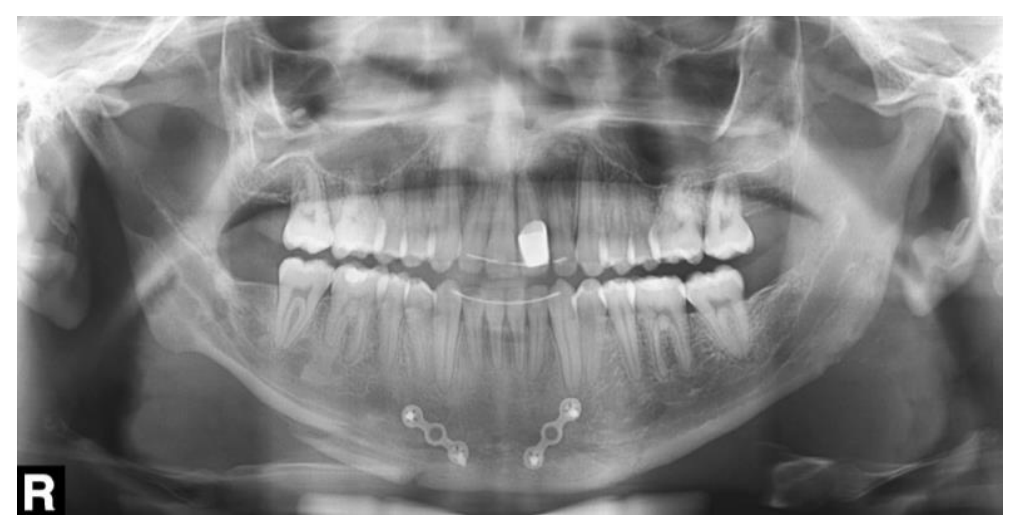

Figure 18. Final panoramic radiograph 

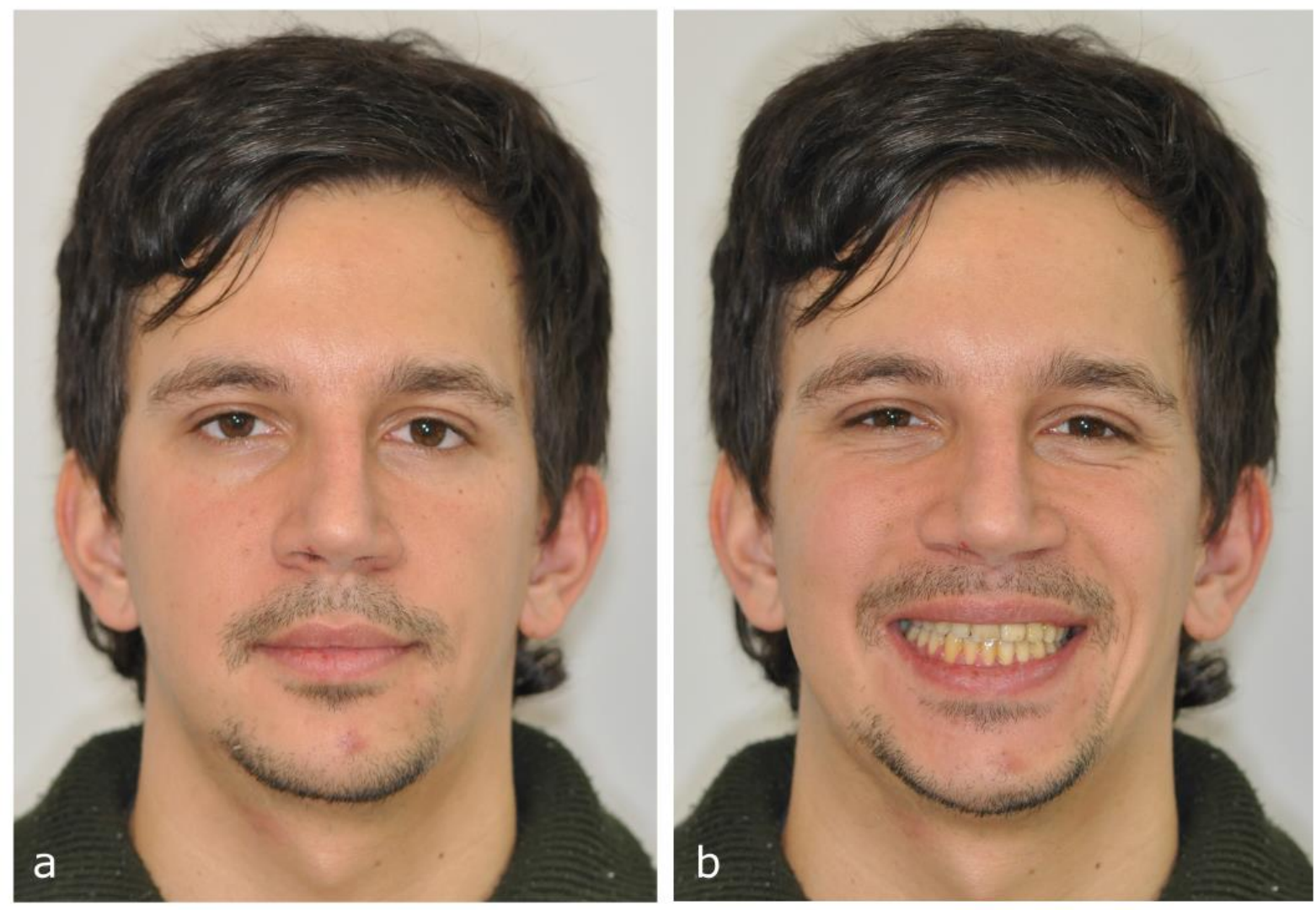

Figure 19. (a) Final facial view (b) Final facial smiling

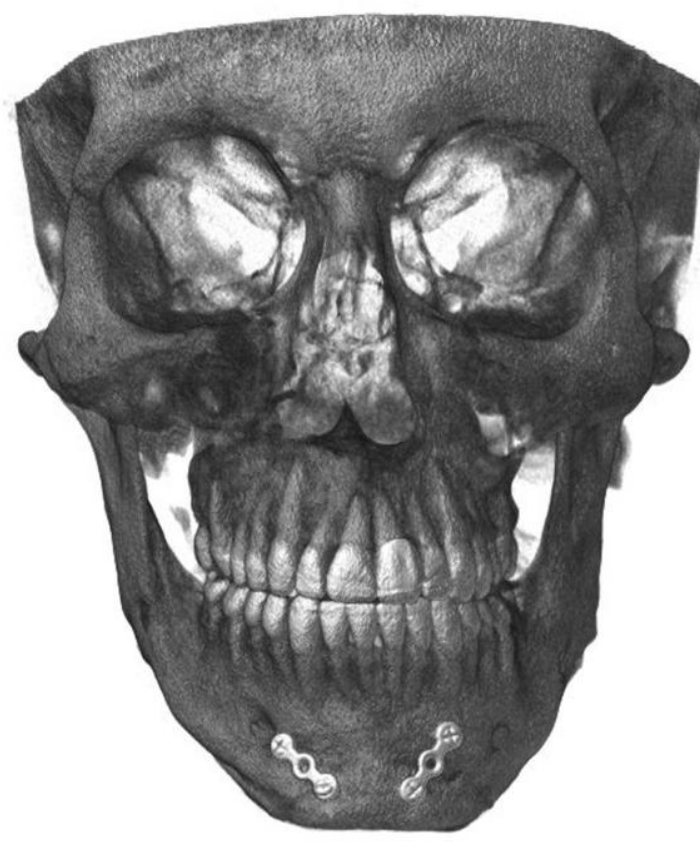

a

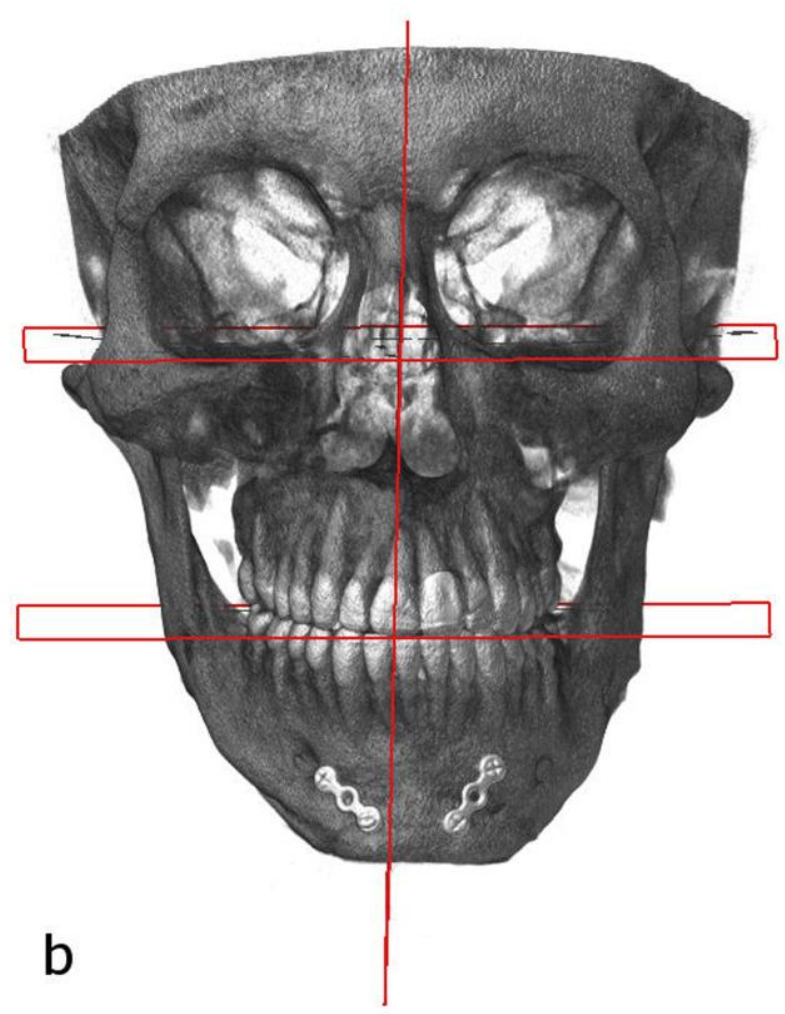

Figure 20. (a) (b) Postoperative CT scan 
Results

A postoperative CT scan was made to evaluate the difference between the virtual Le Fort I osteotomy and the surgical result. The preoperatively planned model of the segmented maxilla was superimposed on the postoperative CT scan. The distance map generated between the superimposed models showed a deviation of $2.15 \mathrm{~mm}$ on the bony structures. (Figure 21).

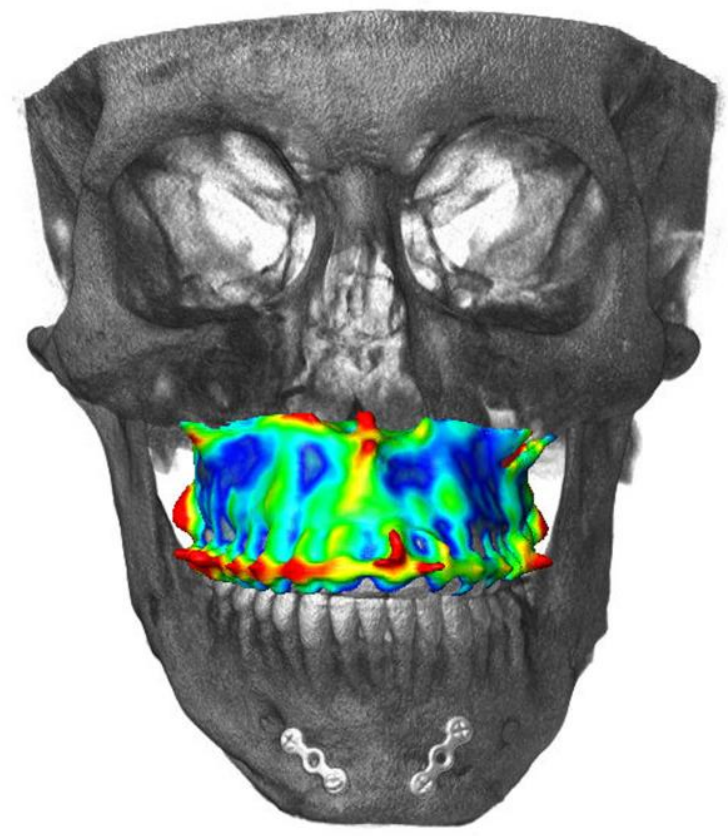

a

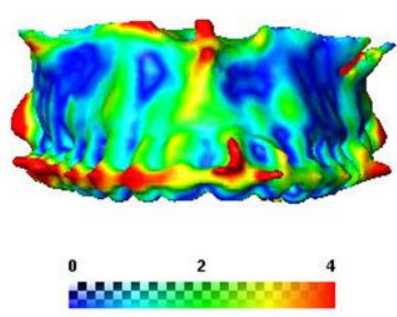

b

Figure 21. (a) (b) Distance map generated from superimposing the virtual plan and the final CT scan

\section{Discussion}

When two-jaw surgery is planned for an asymmetric case spatial positioning of the maxilla is considered more critical than the repositioning of the mandible. Intermediate wafers are used more frequently than the final ones (Parbatani et al 2010). In our case reported, the key point of the procedure was the accurate repositioning of the maxilla. The maxillary segment mobilized via Le Fort I osteotomy showed acceptable intrinsic symmetry, therefore further maxillary osteotomies were not performed. The mobilized unit was placed symmetrically with respect to the sagittal plane. To achieve this it was rotated clockwise until the maxillary occlusal plane was parallel to the interpupillary line. At the same time a further rotation was performed in the horizontal plane to move the posterior part of the maxilla to the right. Amongst others, the complex rotational movement can be one of the sources of inaccuracies in manual model 
surgery. While with traditional methods treatment planning and model surgery are two separate steps, with virtual surgery these two procedures can be performed at the same time, there is no information loss between the two. The most complicated movements can be made precisely and the most accurate measurements can be calculated simultaneously. The final product of virtual model surgery is a virtual splint that can be materialized by rapid prototyping. This technique relies on the accuracy of the virtual model and the production of the surgical splint to ensure a successful surgery (Varga Jr et al 2013). The intermediate wafer was fabricated with the highest printing accuracy in our case and it proved to be the most reliable tool to transfer virtual surgery into the operating room.

The new position of the mandible was determined by the repositioned maxilla. Virtual surgery showed that the mandible would be brought forward by $8.6 \mathrm{mms}$ on the left side. Manual model surgery focuses on the dentition and the occlusion but changes in the bony structure cannot be displayed. Although final wafer was not used as the mandible was simply placed into maximal intercuspal occlusion, virtual surgery still helped us to understand and visualize the rotational movement of the mandible.

\section{Conclusion}

Latest computerized and rapid prototyping technologies let us fully imagine, design and control orthognathic procedures without information loss among the surgeons, orthodontists and dental technicians. Any number of alternative treatment strategies can be investigated simultaneously during the planning phase. Computerised simulation surgery can be extremely useful in severe asymmetric cases when precise treatment planning with traditional methods is hardly possible. With this method manual model surgery and other laboratory steps can be avoided. The surgical wafer splint can be planned virtually and fabricated by a 3D printer. 


\section{UNDERSTANDING GUIDED IMPLANTOLOGY}

i. Aims and Introduction

The aim of this chapter was to understand the potential that guided implantology gives us today. Case reports are demonstrating the possibilities of current technology. Further steps were made to develop an easy to use guided system with a workflow that can be part of the everyday routine.

Prosthetically driven implant surgery in reference to surrounding anatomical structures has been a subject of interest to dental clinicians for a number of years. Correct implant positioning has a number of advantages such as a favourable aesthetic and prosthetic outcome and the potential to ensure optimal occlusion and implant loading. Moreover, the consideration of correct implant positioning may enable design optimization of the final prostheses, allowing for adequate dental hygiene. Consequently, all of these factors may contribute to the long-term success of dental implants. (Tahmaseb 2014).

j. The Use of CAD/CAM Technology in Implant Surgery and Prosthetics.

The growing use of CAD/CAM technology in implant dentistry makes treatment planning and performing easier, faster, predictable and more comfortable for the patient. Guided implantology may not only ensure minimal invasive treatments but also leads to prosthetically optimal implant positions. The possibilities in current technology from patient arrival to the final restoration will be shown in this case report.

This report shows a rehabilitation of a totally edentulous maxilla.

\section{Case Presentation}

The patient is a 36 years old female with a completely edentulous upper jaw. The reason of teeth loss were negligent dental care and lack of oral hygiene. She was wearing acrylic complete denture. Implant placement could not be carried out due to the extensive horizontal and vertical atrophy of the maxilla (Figure 22). 


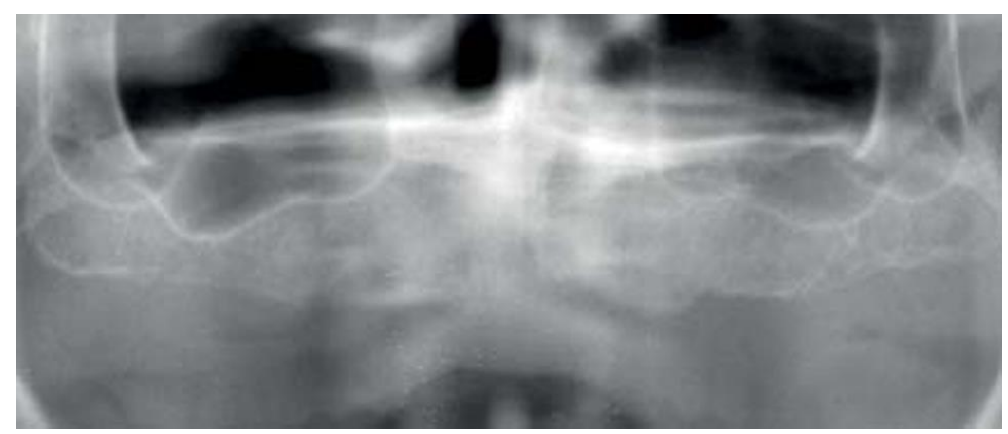

Figure 22. Pre-operative panoramic X-ray from the maxilla

Oral and radiological examination was followed by a comprehensive discussion with the patient. The detailed treatment plan contained the augmentation of the alveolar bone with autologous bone graft from the mental region and bilateral sinus elevation (Figure 23). Healing process was followed by computerized planning of the implant positions and guided placement of six implants. Digital process was used to design and fabricate the final prosthesis.

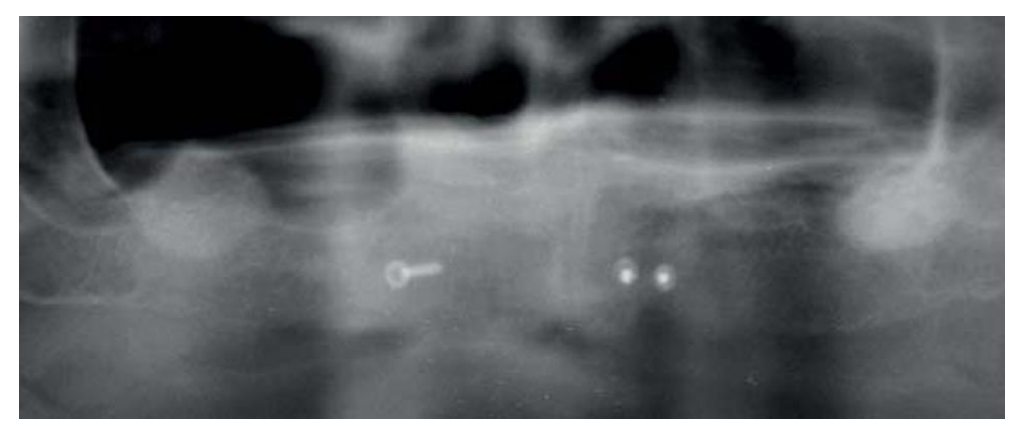

Figure 23. Panoramic X-ray after bone grafting and bilateral sinus elevation

Material and Methods

Implant planning was performed after four months of bone healing. A CT template was fabricated according to the existing complete denture in order to visualize the prosthetic concept (Figure 24). Imaging was performed according to the manufacturer's double-scan technique. The technique requires a scan from the patient wearing the CT template in place and a second CT scan from the template itself (Figure 25). The CBCT was carried out with standard parameters. The DICOM files were transferred into a commercially available planning software (NobelClinician, Nobel Biocare Services AG). 


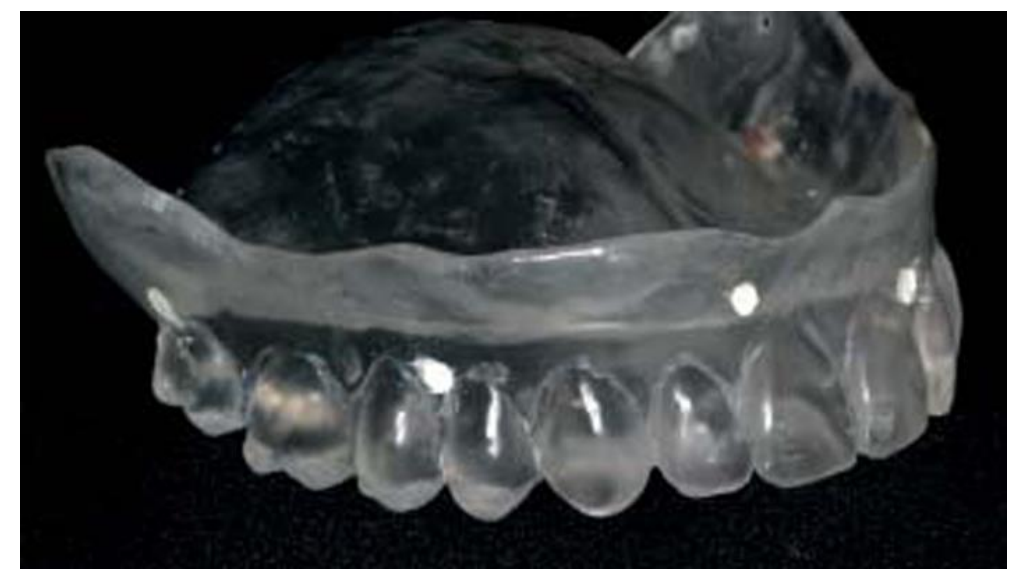

Figure 24. CT template with the registration markers

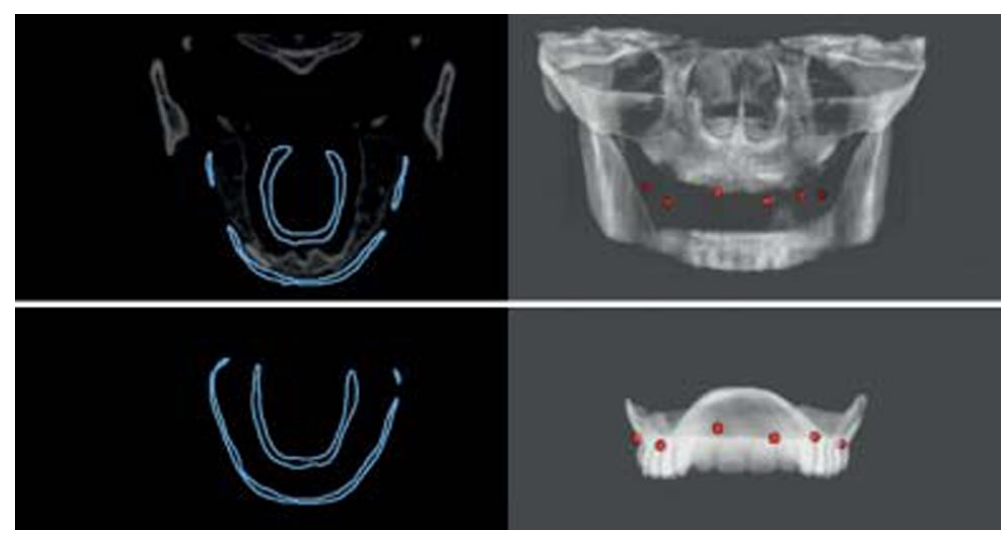

Figure 25. The two separate image data from the dual-scan technique

As a first step before the planning procedure the border lines of the bony structures and the CT template must be defined (threshold segmentation). It is followed by registration of the two models according to the registration markers contained by the CT template. A merged three dimensional model for surgical planning is the result of these procedures (Figure 26).

The types, sizes and positions of the implants along with the location of the fixation pins were determined in the planning software. The plan was sent to the manufacturer (Figure 27). 


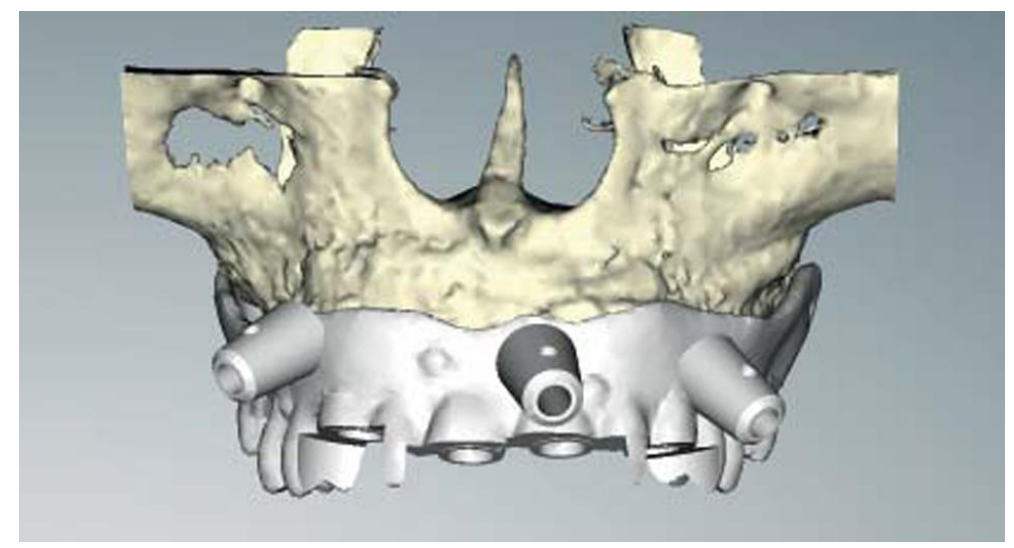

Figure 26. The merged three dimensional model for surgical planning
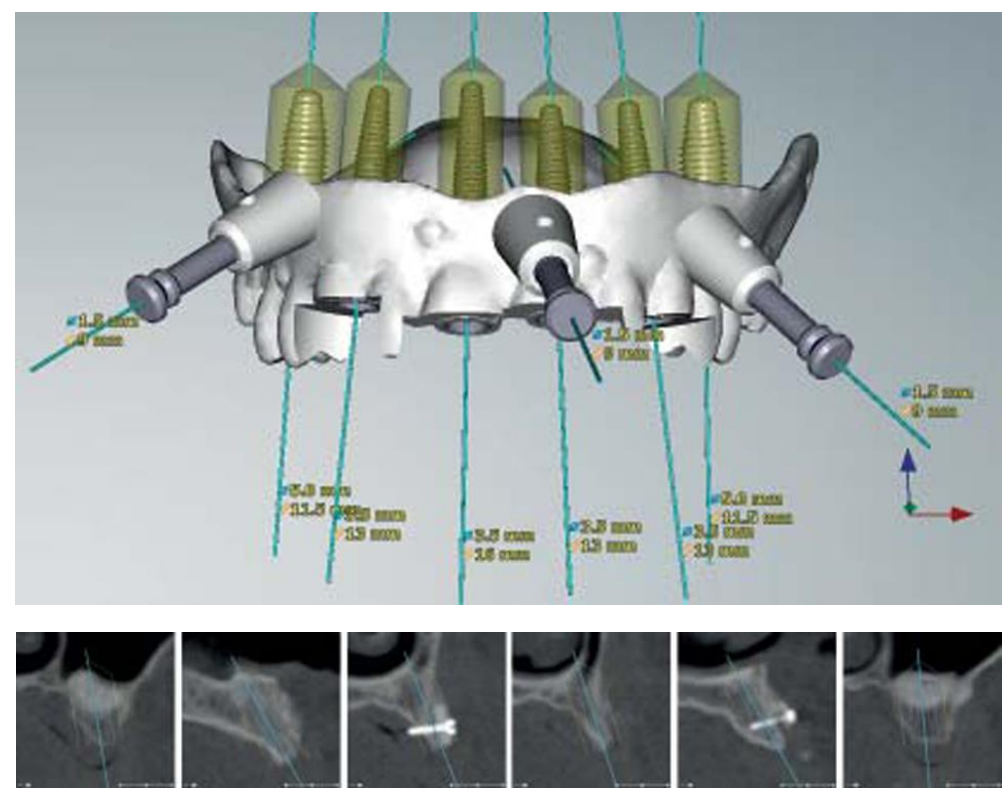

Figure 27. The planned implant positions in three-dimension and on cross-sections

The surgery was performed two weeks after the planning (Figure 28). The primer stability of the implants were satisfactory therefore transgingival healing abutments were used. The inside of the patient's complete denture was modified not to load the healing abutments during the three months of healing. 


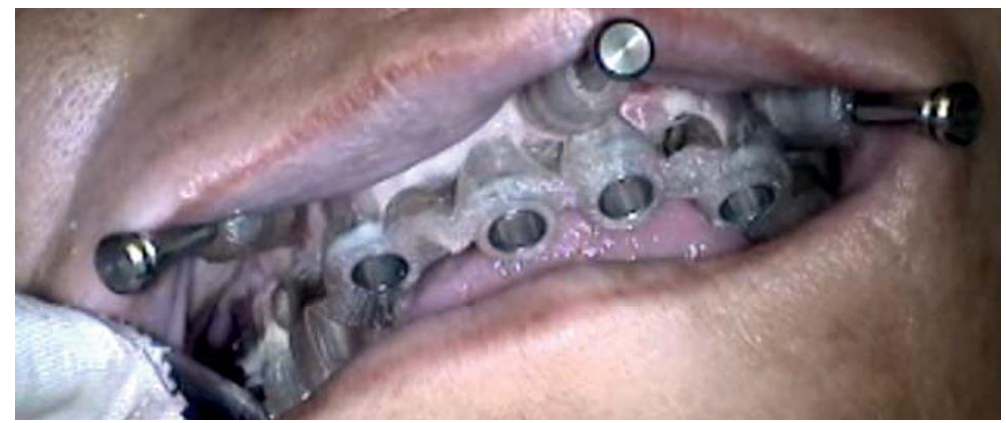

Figure 28. The surgical guide in its place during surgery

Screw-retained ceramic bridge on zirconia frame was planned with Procera technology (NobelProcera, Nobel Biocare Services AG) (Figure 29). The teeth position of the complete denture was taken into consideration when planning the framework on the computer. The digital plan was sent to the manufacturer and the final framework was received three days later (Figure 30). The ceramic work was performed locally and finalized within a few intraoral try-ins (Figure 31).
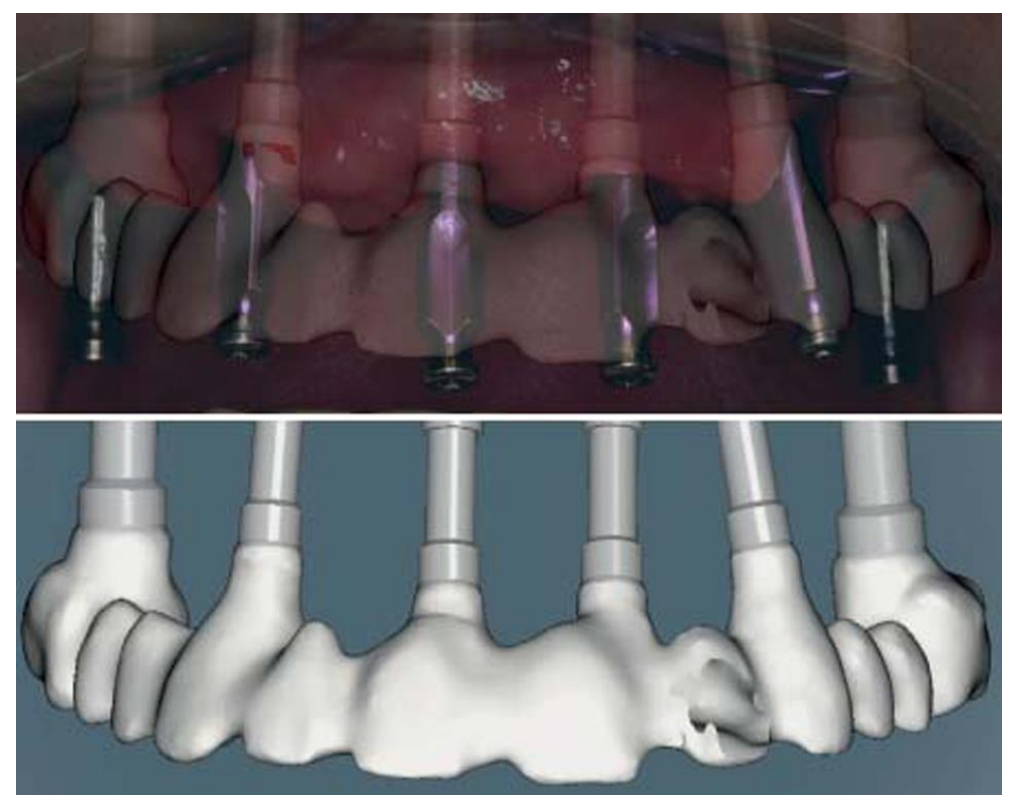

Figure 29. The digital plan of the framework superimposed on the impression abutments and separately 


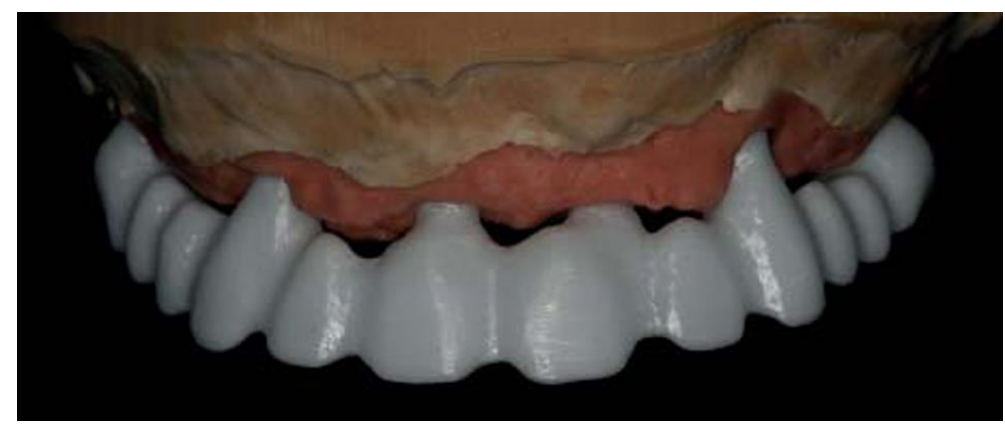

Figure 30. The zirconium framework on the plaster model
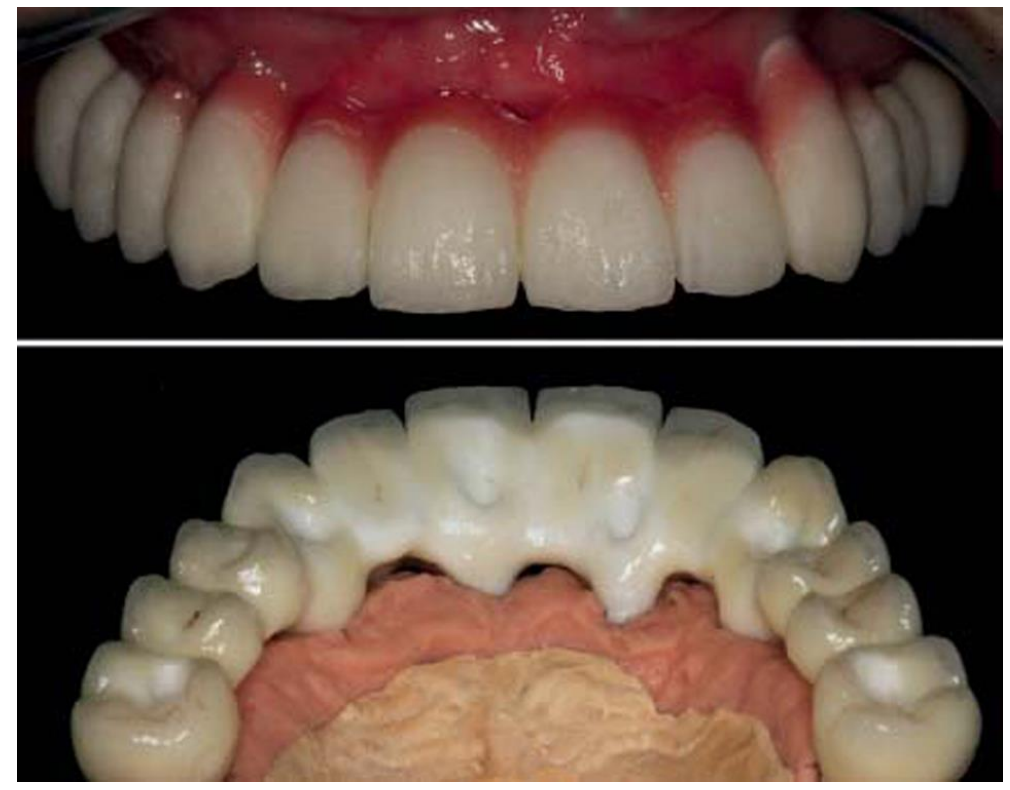

Figure 31. Finalization of the ceramic masking

\section{Results}

Since the alveolar bone had not reach the optimal dimensions after bone grafting, pink ceramic was used to improve the aesthetic outcome. The patient was satisfied with the result (Figure 32, $33)$. 


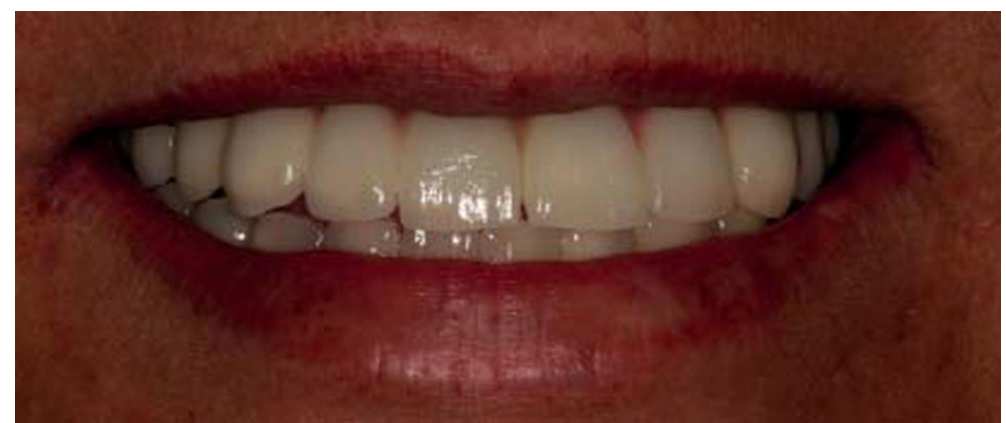

Figure 32. The final result

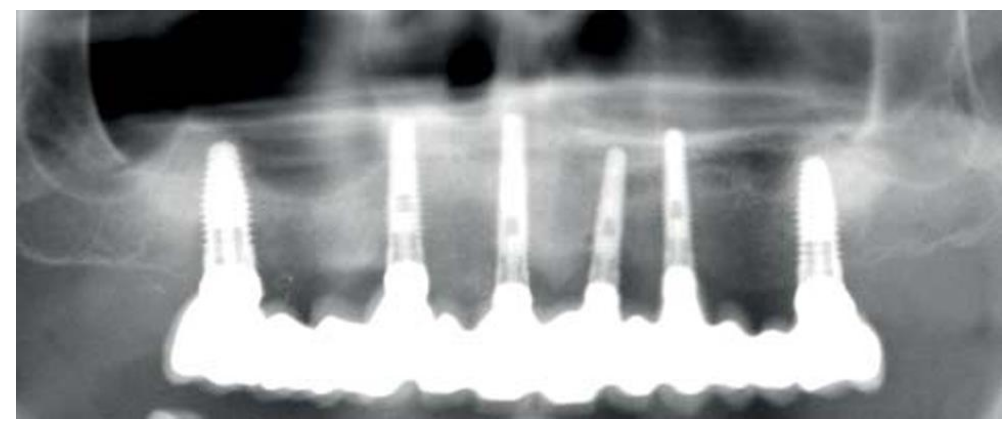

Figure 33. Control X-ray three months post-operatively

\section{Conclusion}

Modern CAD/CAM technologies play an important role in prosthetic planning. The presented case demonstrates all steps of the state of the art in virtual planning which might be used in the everyday practice. With the use of these technologies not only can unexpected complications can be avoided but surgeries can be more accurate with the higher aesthetic standards and prosthetic guidelines achieved.

k. Method and System for Designing and Manufacturing Surgical Guides

The subject of the invention is a method and system for a fast and precise way of designing and manufacturing surgical guides.

The method begins with an impression from the oral structures made with an impression tray containing radiographic markers. The patient is digitized with the impression tray in its place and the impression tray is digitized separately. The two digital data stacks are than registered 
with a treatment planning software and the digital treatment plan is made. The digital model of the surgical guide is then made with a guide designing software. The physical model of the surgical guide is than manufactured according to the digital model (Figure 34).

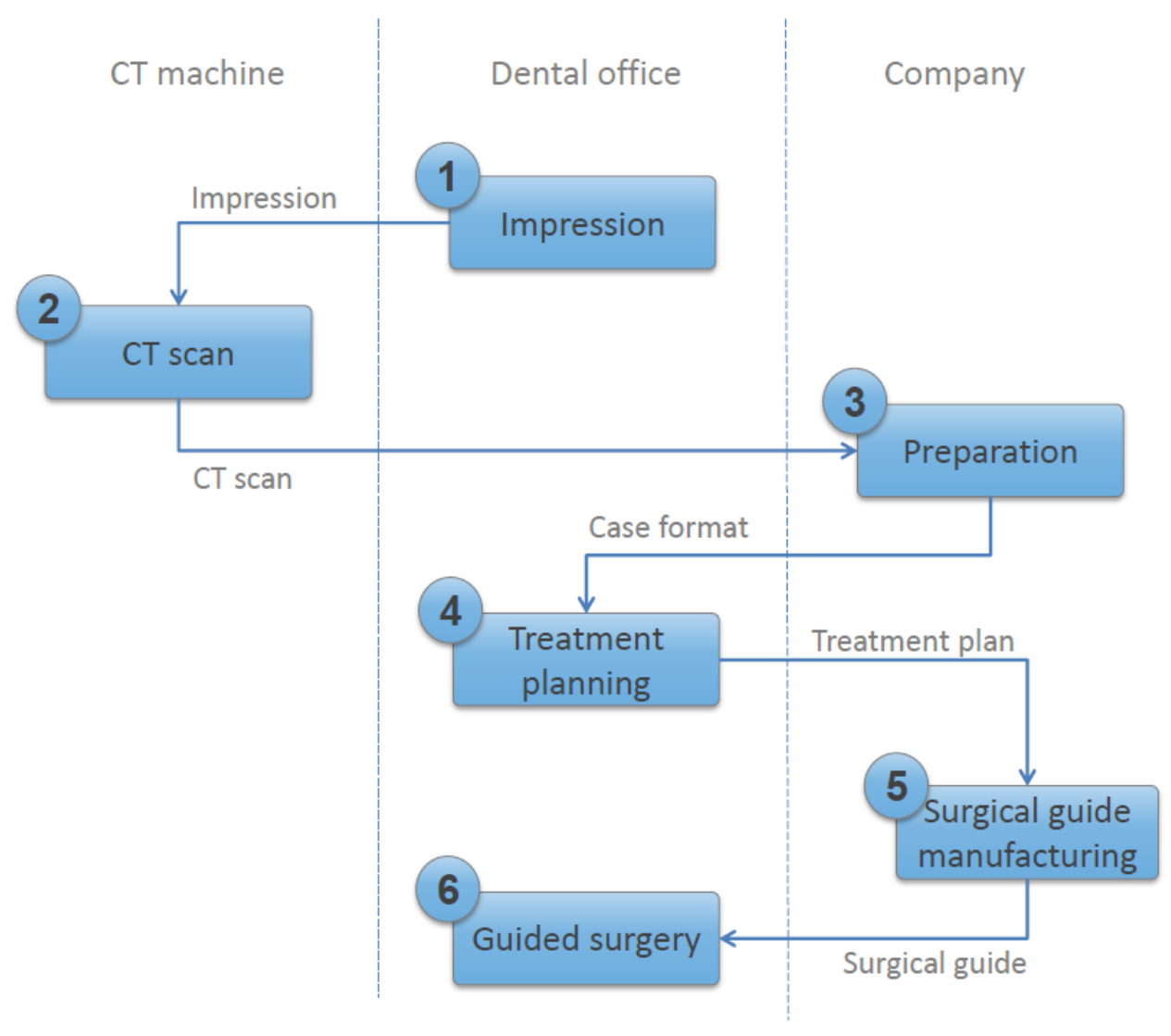

Figure 34. The workflow for designing and manufacturing surgical guide

The system contains planning software for registration and treatment planning, a guide design software for crating the digital model and the physical model of the guide, a surgical kit and the planned and manufactured patient's specific surgical guides.

\section{The Present State of the Technology}

Implant surgical guides used for all types of edentulous cases are made by the following workflow. As a first step the dental technician makes the casts from the upper and lower impressions, than they are articulated with the help of the bite registration. The dimensions and extensions of the surgical guide is designed and crafted by the dental technician. This is a time consuming manual procedure when the final borderlines are taken into consideration. The 
undercuts of the dentition would prevent the solid material of the surgical guide to fit in the correct position. These undercuts needs to be blocked out usually with heated wax or other hardening material. This step can be especially time consuming.

The prepared cast is than moulded by a self-curing acrylic material with the help of a silicone moulding form shaped on the borderlines. Post processing steps such as finishing and polishing are made on the template. As a final step a defined number of radiographic markers are placed into the right locations of the template.

The radiographic template than needs to be tried in the patient's mouth in order to control the fit. Due to the high requirement of the fitting, the process needs to be repeated for even the smallest inaccuracy. The imaging can then be performed with a well-fitting template.

The imaging is made with the so-called dual-scan protocol. It means that the first scan is made with the template in the patient's mouth and the second scan is made from the template separately.

The need for the dual-scan is due to the fact that CBCT gives excellent images from the hard structures but it is lacking in information on the soft tissue. Therefore a sub-totally or totally edentulous situation could not be solved without visualizing the soft tissues. The dual scan protocol and the radiographic template ensures that the position and relation of the hard and soft tissues are correct. The registration is made with the markers fitted in the template therefor visible on both image data.

The treatment plan is made by the doctor. The types, shapes, sizes and location of the implants need to be determined. This plan is then input to the three-dimensional printer to fabricate the physical model of the surgical guide.

The procedure of hand manufacturing the radiographic template by the technician is timeconsuming, costly and carries the chance of inaccuracy due to hand crafted steps. 
Presenting the Invention

The technology presented in this invention also operates with the dual-scan protocol. It uses an impression tray with radiographic markers fitted on (hereinafter ,tray”). The first scan is made having the tray with the impression in the patient's mouth and the second scan is made from the tray with the impression separately.

The radiographic markers are spherical radio dens points integrated in the material of the impression tray in a specified number and position.

The significance of registration is when the planning software superimposes the identical marker points automatically. Therefore the two data stacks gets in the same coordinate system in the three-dimensional space. With this transformation a file format for planning is achieved. The treatment plan is performed in the planning software. It contains the type of the surgical kit as well as the type, sizes and positions of the implants.

The plan together with the digital model of the impression is then transferred to a surgical guide designing software. As a first step the border lines and the dimensions of the surgical guide are determined. These steps are made by a dental technician in a computer program. The following step is to remove the undercuts from the model. For that the direction of the guide insertion has to be shown. This procedure is crucial since the material of the surgical guide is more rigid than the impression material. This leads to the perfect fit of the surgical guide during operation. The location of the tubes holding the metal sleeves in the future are determined by the plan. The shapes and dimensions of the tubes are given in the computer program to achieve maximum stability of the device. The insertion of the surgical tools are simulated virtually therefore free tool insertion and comfortable surgery is ensured. The patent ID is then placed on the surface of the surgical guide. The software generates the final three-dimensional model of the surgical guide which is then manufactured by a three-dimensional printer. The software also produces a patient specific surgical protocol. The protocol contains all the details of the planned implants, and a sequence of the drills needed to be used for the perfect result (Figure 35). 


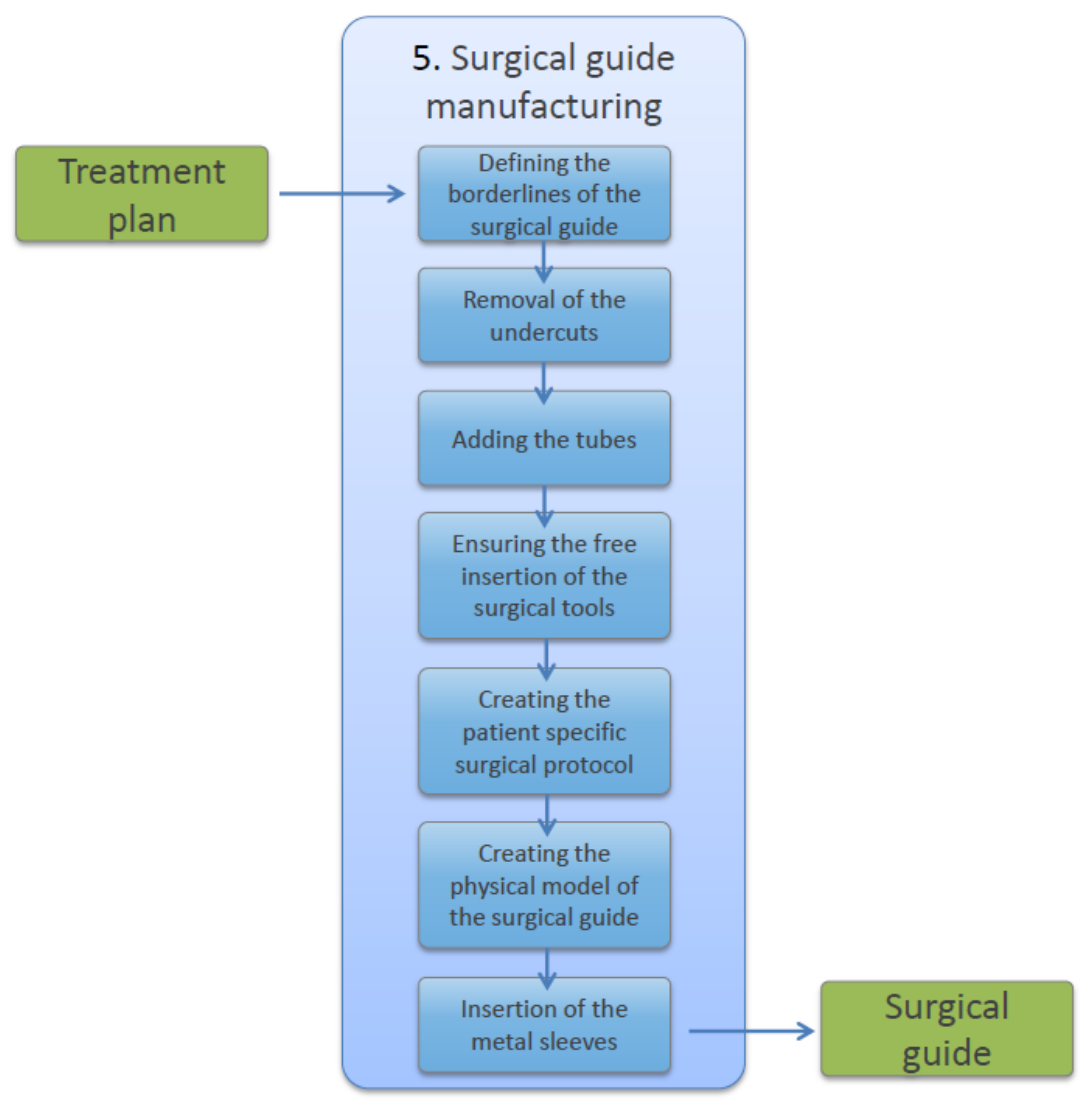

Figure 35. The method for surgical guide manufacturing

The printed model of the guide then goes through some additional finalizing steps such as polishing, insertion of the metallic sleeves and cleaning.

The Advantages of the Method

The method shown in this invention allows the user to perform the CBCT imaging right at the first patient visit without the need of the intervention of dental technician, manufacturing of plaster casts or using surface scanning devices. The invention saves significant time and cost for both the doctor and the patient. Furthermore the exposure to inaccurate procedures such as creating plaster casts or fabricating scan appliances are eliminated. 


\section{Conclusions}

The invention offers a solution for easy, fast, accurate and cost effective manufacturing of surgical guides. The method eliminates the need for the time consuming and costly production of scan appliances. The invention makes planning and performing guided surgery easier and compatible with everyday practice. 


\section{Discussion}

This thesis focused on the importance of medical imaging, image processing, accuracy and the implementation of new technologies. The research shown in this work targeted orthognathic surgery and dental implantology as the fields with the uppermost patient demands therefore requiring the highest precision.

No image processing step can compensate for lack of resolution in the original data. Inadequate resolution amplifies the negative effects of image processing. However, image processing can severely degrade the quality of a model generated from high-resolution data. The introduction and widespread use of cross-sectional imaging in maxillofacial surgery and implant dentistry using cone beam computed tomography (CBCT) makes appropriate imaging accessible. Although latest CBCT machines have their benefits, radiation dose have to be considered. CBCT imaging exhibits a significantly lower radiation dose risk than conventional CT, but higher than that of two-dimensional radiographic imaging. Different CBCT devices deliver a wide range of radiation doses. Substantial dose reduction can be achieved by using appropriate exposure parameters and reducing the field of view to the actual region of interest (De Vos et al 2009, Bornstein et al 2014).

The evaluations shows that not only the image resolution but also each processing step effects the quality and accuracy of the 3D model. Each step is dependent on the image processing techniques chosen in previous steps. Errors introduced early in the workflow are multiplied by subsequent image processing steps. Particularly, early decisions made during manipulation of label field data in 2D scans have a dramatic effect on final model accuracy (Varga Jr et al 2013). A potentially satisfactory alternative to $3 \mathrm{D}$ model generation from CT data is optical scanning of dental structures. Use of this technique does not escape the need for CT in many cases, nor does it eliminate accuracies from 3D model image processing. If detail of the underlying structures is needed for surgical planning, CT scanning is still required, as is often the case in orthognatic and surgical procedures affecting dental structures. An additional source of error within optical scanning is the merging and alignment of CT-derived and optical scan-derived model data (Schutyser et al 2005, Swennen et al 2008). Finally, models generated from optical surface scanning must still undergo image processing of the 3D model, potentially introducing the inaccuracies detailed in this study.

Accurate 3D models require a combination of appropriate resolution imaging and image processing. The importance of resolution in the source imaging is well understood by surgeons. 
The critical nature of image processing is poorly recognized and this study demonstrates it as a source of significant error. Adequate quality models can be produced using average resolution CT scanners as long as the importance of image processing is understood.

Computerized planning and the use of digital data gives the possibility to fully imagine, design and control surgical procedures without information loss among the surgeons, orthodontists and dental technicians. Any number of alternative treatment strategies can be investigated simultaneously during the planning phase. However these new techniques have to be learned by each professional of the team and they do not substitute the anatomical knowledge and surgical skills.

The results gained in the case report of the correction of a severe facial asymmetry are showing promising results, however evaluation of more cases will be needed to show significance.

The systematic review indicates that computer technology applications in implant dentistry are sufficiently accurate to justify use. There are sometimes however concerns over some of the reported accuracies, which indicates maximum deviations from the planned position that exceeded clinically acceptable parameters. It is suggested by the author of the paper that this might be due to intraoperative movement of the surgical template. (Hämmerle et al 2009). Guided implantology requires a different surgical technique than conventional free-hand implant placement. The operator has to rely on the surgical guidance which is often an unusual sensibility. The learning curve for this procedure could be quite steep, so caution should be exercised in the early stages of acquiring these skills. (Jung et al 2009).

Computer-assisted implant placement reveals high implant survival rates after 12 months of observation. However, future long-term clinical data are necessary to identify clinical indications and to justify effort, and costs associated with computer-assisted implant surgery (Tahmaseb et al 2014).

Guided implant site preparation is often used as a synonym for flapless or trans-gingival approach. Surgical access of the soft tissue should be chosen by the clinician by evaluating the clinical situation. Flaps can be also raised when using surgical guide, however the correct fit of the template must be controlled. Guided surgery gives the possibility for trans-gingival implant site preparation and implant placement. 
Flapless surgery appears to be a plausible treatment modality for implant placement, demonstrating both efficacy and clinical effectiveness. However, these data are derived from short-term studies with a mean interval of 19 months, and a successful outcome with this technique is dependent on advanced imaging, clinical training, and surgical judgment. (Bordala 2009).

Computerized treatment planning is an exceptionally interdisciplinary area of imaging, computer science, engineering and medicine. Each professional need to be able to discuss with the other to understand the nature and the potential in this field. The extremely fast development of this topic makes this an interesting area for research, education and development which has to be reviewed day by day. 


\section{Summary}

The aim of this research was to understand the basics and approaching the questions in a scientific way. The following statements are made based on this research:

1. How much effect does the resolution of imaging have on the accuracy of a threedimensional model used for surgical planning?

Inadequate resolution amplifies the negative effects of image processing. Beginning with the highest resolution, the data revealed a linear increase in the deviations between the models generated from reduced resolution CT scans and the gold standard model. For each image resolution, the max+/max- values showed similar absolute deviation values. Between the highest and lowest resolution, there was a four-fold increase of the deviation. The distance maps demonstrated a uniform deviation pattern on the occlusal surfaces.

2. How much effect do the further digital imaging steps have on the accuracy of a model? Image processing can severely degrade the quality of a model generated from high-resolution data. Each step is dependent on the image processing techniques chosen in previous steps. Errors introduced early in the workflow are multiplied by subsequent image processing steps. Particularly, early decisions made during manipulation of label field data in 2D scans have a dramatic effect on final model accuracy. The effects of the following image processing steps were shown: thresholding procedure, smoothing of the labeled threshold data, different model generation techniques, smoothing the surface model and reducing the number of triangles of the surfaces.

3. How accurate is an orthognathic surgery planned virtually?

The distance map evaluation showed a mean deviation between the pre-operative plan and the post-operative outcome of $3,94 \mathrm{~mm}$ with a standard deviation of 1,26 $\mathrm{mm}$.

4. Is improving accuracy of the post-operative outcome possible? 
The results of the case report shows improving of the accuracy is possible. Deviation of 2,15 mm was shown however further evaluations need to be made.

5. Implementing the experiences in guided implantology.

The knowledge gained in 3D modelling, computerized planning and rapid prototyping helps to understand the details of guided implantology. Further accuracy studies are running at the present.

6. A method and system for designing and manufacturing surgical guides

The subject of the invention is a method and system for a fast and precise way of designing and manufacturing surgical guides. The patent is currently pending. 


\section{Acknowledgements}

First of all I would like to thank Prof. Dr. Dr József Piffkó, Head of Department of Oral and Maxillofacial Surgery and Prof. Dr. Endre Varga, Head of Department of Traumatology for their great help and supervision. Prof. Piffkó always believed and supported my ideas through the years and gave me all the clinical knowledge in the topic. His high expectations guided me over the last period of time. Prof. Varga, my father, influenced me and my professional choices all in my life. His scientific work astonished me ever since my childhood and it is an inexpressible feeling to follow his path in my profession. Without him this thesis would have remained an imagination.

Special thanks to Prof. Dr. Katalin Nagy, Dean of Faculty of Dentistry, who was always a supportive stronghold from the beginning of my dental education and through in my early career.

One of the most determinant phase of my post-graduate studies was the year which I have spent in the AO Research Institute (ARI) in Davos, Switzerland. I would like to express my gratitude to Prof. R. Geoff Richards, the Director of AO Research and Development. He is a great scientist and a fantastic leader who was always supporting us young fellows.

I would also like to express my gratitude to the two most special colleagues of mine, Balázs Erdőhelyi and Balázs Bagó software engineers, who we are always searching the common ground to develop great products in digital medicine.

Emphasized thanks to my Swiss mentor and supervisor, Dr. Lukas Kamer, Focus Area Leader of Human Morphology Services, ARI. He showed me the beauty of research and the possibilities it might carry. No days are passed without thinking of the great talks and discussions we had. Here I would like to say thank you to all the great colleagues, Prof. Hansrudi Noser, Thomas Heldstab, Prof. Dr. Beat Hammer, Dr. Dennis Rohner, Ryan Seelbach, Dr. Fabian Duettenhöfer, Dr. Stephan Arlt, Dr. Angharad Simpson, Dr. Ben M. Hardy, Cassie Tillas, Jürgen Staiger, Dr. Riccardo Dalla Costa and Michelle Baucke, who I met in the ARI or somewhere in Switzerland.

It is a great pleasure to acknowledge the support of Dr. Béla Czinkóczky, who is my greatest clinical mentor in implantology. His professional attitude and enormous patience showed me the right path. Also special thanks to my fantastic colleagues, Dr. László Seres, Dr. András Kocsis, Dr. Zoltán Raskó, Dr. Viktória Korpásy and Dr. Virág Varga. 
Among those to be thanked, Dr. Márk Antal deserves a highlighted place for the ideas we share and the endless talks we can have on related topics.

It is a fortune that I can also thank to a great team who gathered together to do research and develop technologies related to this topic. Special thanks to András Domonkos who saw the opportunity and believes in my idea ever since our first talk. Great thanks to Brigitta Kardos, Stefánia Ostrogonac, Zsuzsa Erben, Jenő Huszka and István Major.

This thesis would not have been possible without the support of my mom, dad and sister.

Finally I thank to a really special person, my lovely fiancée, Nicole, who left the Swiss mountains to support me and this work.

Thank you all! 


\section{References}

Alves PV, Bolognese AM, Zhao L. Three-dimensional computerized orthognathic surgical treatment planning. Clin Plast Surg. 2007 Jul;34(3):427-436. Review.

Amet EM, Ganz SD. "Implant treatment planning using a patient acceptance prosthesis, radiographic record base, and surgical template. Part 1: Presurgical phase." Implant Dent. 1997 Fall;6(3):193-197.

Baek SH, Kang SJ, Bell WH, Chu S, Kim HK. Fabrication a surgical wafer splint by threedimensional virtual model surgery. In: Bell WH, Guerrero CA, eds: Distraction Osteogenesis of the Facial Skeleton. Hamilton, Ontario Canada: BC Decker Inc; 2007:115-130.

Belyaev A. A Comparison of Mesh Smoothing Methods. Computer 2003;2:1-5.

Bogdán S, Huszár T, Joób Fancsaly A, Németh Z, Pataky L, Barabás J. [The clinical importance of the mandibular canal course variations]. Fogorv Sz. 2006 Aug;99(4):169-173.

Bornstein MM, Scarfe WC, Vaughn VM, Jacobs R. Cone beam computed tomography in implant dentistry: a systematic review focusing on guidelines, indications, and radiation dose risks. Int J Oral Maxillofac Implants. 2014;29 Suppl:55-77. doi: 10.11607/jomi.2014suppl.g1.4.

Brodala N. Flapless surgery and its effect on dental implant outcomes. Int J Oral Maxillofac Implants. 2009;24 Suppl:118-125. Review.

Cevidanes LH, Tucker S, Styner M, Kim H, Chapuis J, Reyes M, Proffit W, Turvey T, Jaskolka M. Three-dimensional surgical simulation. Am J Orthod Dentofacial Orthop. 2010 Sep;138(3):361-371. doi: 10.1016/j.ajodo.2009.08.026.

Chappuis V, Engel O, Reyes M, Shahim K, Nolte LP, Buser D. Ridge alterations post-extraction in the esthetic zone: a 3D analysis with CBCT. J Dent Res. 2013 Dec;92(12 Suppl):195-201. doi: 10.1177/0022034513506713. Epub 2013 Oct 24. 
Cheong YW, Lo LJ. Facial asymmetry: etiology, evaluation, and management. Chang Gung Med J. 2011 Jul-Aug;34(4):341-351. Review.

Choi JY, Song KG, Baek SH. Virtual model surgery and wafer fabrication for orthognathic surgery. Int J Oral Maxillofac Surg. 2009 Dec;38(12):1306-1310. doi: 10.1016/j.ijom.2009.06.009.

Cousley RR, Turner MJ. Digital model planning and computerized fabrication of orthognathic surgery wafers. J Orthod. 2014 Mar;41(1):38-45. doi: 10.1179/1465313313Y.0000000075. Epub 2013 Nov 14.

De Vos W, Casselman J, Swennen GR. Cone-beam computerized tomography (CBCT) imaging of the oral and maxillofacial region: a systematic review of the literature. Int J Oral Maxillofac Surg. 2009 Jun;38(6):609-25. doi: 10.1016/j.ijom.2009.02.028. Epub 2009 May 21. Review. PubMed PMID: 19464146.

Donatsky O, Bjørn-Jørgensen J, Hermund NU, Nielsen H, Holmqvist-Larsen M, Nerder PH. Accuracy of combined maxillary and mandibular repositioning and of soft tissue prediction in relation to maxillary antero-superior repositioning combined with mandibular set back A computerized cephalometric evaluation of the immediate postsurgical outcome using the TIOPS planning system. J Craniomaxillofac Surg. 2009 Jul;37(5):279-284. doi: 10.1016/j.jcms.2008.12.003. Epub 2009 Feb 1.

Edler R, Wertheim D, Greenhill D. Outcome measurement in the correction of mandibular asymmetry. Am J Orthod Dentofacial Orthop. 2004 Apr;125(4):435-443.

Ellis E $3^{\text {rd }}$. Accuracy of model surgery: evaluation of an old technique and introduction of a new one. J Oral Maxillofac Surg. 1990 Nov;48(11):1161-1167.

Erdőhelyi B, Varga E, Kuba A. Surgical Planning Tool with Biomechanical Simulation. Proceedings of the International Conference on Computer Assisted Radiology and Surgery (CARS). Int J Comput Assist Radiol Surg 2007;2:262-263. doi: 10.1007/s11548-007-0098-0 
Favero L, Terrazzani C, Favero V, Stellini E, Cocilovo F. Virtual study models: a comparison of modular application systems. Prog Orthod. 2009;10(2):16-25.

Fortin T, Isidori M, Bouchet H. Placement of posterior maxillary implants in partially edentulous patients with severe bone deficiency using CAD/CAM guidance to avoid sinus grafting: a clinical report of procedure. Int J Oral Maxillofac Implants. 2009 Jan-Feb;24(1):96102.

Garland M, Heckbert PS. Surface simplification using quadric error metrics. ACM 1997;209216.

Gateno J, Xia J, Teichgraeber JF, Rosen A. A new technique for the creation of a computerized composite skull model. J Oral Maxillofac Surg. 2003 Feb;61(2):222-227.

Gateno J, Xia JJ, Teichgraeber JF. A new three-dimensional cephalometric analysis for orthognathic surgery. J Oral Maxillofac Surg. 2011 Mar;69(3):606-622. doi: 10.1016/j.joms.2010.09.010. Epub 2011 Jan 22.

Cline HE, Lorensen WE. System and method for the display of surface structures contained within the interior region of a solid body 1987;12: Patent Number: US 4710876 A.

Hämmerle $\mathrm{CH}$, Stone $\mathrm{P}$, Jung RE, Kapos T, Brodala N. Consensus statements and recommended clinical procedures regarding computer-assisted implant dentistry. Int J Oral Maxillofac Implants. 2009;24 Suppl:126-31. PubMed PMID: 19885440.

Heitz-Mayfield LJ, Needleman I, Salvi GE, Pjetursson BE. Consensus statements and clinical recommendations for prevention and management of biologic and technical implant complications. Int J Oral Maxillofac Implants. 2014;29 Suppl:346-350. doi: 10.11607/jomi.2013.g5.

Hernández-Alfaro F, Guijarro-Martínez R. New protocol for three-dimensional surgical planning and CAD/CAM splint generation in orthognathic surgery: an in vitro and in vivo study. Int J Oral Maxillofac Surg. 2013 Dec;42(12): 1547-1556. doi: 10.1016/j.ijom.2013.03.025. Epub 2013 Jun 13. 
Hsu SS, Gateno J, Bell RB, Hirsch DL, Markiewicz MR, Teichgraeber JF, Zhou X, Xia JJ. Accuracy of a computer-aided surgical simulation protocol for orthognathic surgery: a prospective multicenter study. 2013 Jan;71(1):128-142. doi: 10.1016/j.joms.2012.03.027. Epub 2012 Jun 12.

Hwang HS, Hwang CH, Lee KH, Kang BC. Maxillofacial 3-dimensional image analysis for the diagnosis of facial asymmetry. Am J Orthod Dentofacial Orthop. 2006 Dec;130(6):779-785.

Ikumi N. "Procedure of highly predictable implant treatment. A role of CT scan in implant treatment planning. Part 1". The Quintessence 1995;14(11):5-14.

Jacobs R. Dental cone beam CT and its justified use in oral health care. JBR-BTR. 2011 SepOct;94(5):254-265. Review.

Jung RE, Schneider D, Ganeles J, Wismeijer D, Zwahlen M, Hämmerle CH, Tahmaseb A. Computer technology applications in surgical implant dentistry: a systematic review. Int J Oral Maxillofac Implants. 2009;24 Suppl:92-109. Review. PubMed PMID: 19885437.

Klein M, Abrams M. "Computer-guided surgery utilizing a computer-milled surgical template". Pract Proced Aesthet Dent. 2001 Mar;13(2):165-169; quiz 170.

Lambrecht JT, Brix F. Planning orthognathic surgery with three-dimensional models. Int $\mathbf{J}$ Adult Orthodon Orthognath Surg. 1989;4(3):141-144.

Levine JP, Patel A, Saadeh PB, Hirsch DL. Computer-aided design and manufacturing in craniomaxillofacial surgery: the new state of the art. J Craniofac Surg. 2012 Jan;23(1):288293. doi: 10.1097/SCS.0b013e318241ba92.

Lorensen WE, Cline HE. Marching cubes: A high resolution 3D surface construction algorithm. Computer Graphics 1987;21(4):163-169. 
Loubele M, Maes F, Schutyser F, Marchal G, Jacobs R, Suetens P. Assessment of bone segmentation quality of cone-beam CT versus multislice spiral CT: a pilot study. Oral Surg Oral Med Oral Pathol Oral Radiol Endod. 2006 Aug;102(2):225-234. Epub 2006 Apr 21.

Luebke DP. A Developer's Survey of Polygonal Simplification Algorithms. IEEE 2001 May;21(3):24-35.

Marchetti C, Bianchi A, Bassi M, Gori R, Lamberti C, Sarti A. Mathematical modeling and numerical simulation in maxillo-facial virtual surgery (VISU). J Craniofac Surg. 2006 Jul;17(4):661-667; discussion 668.

Metzger MC, Hohlweg-Majert B, Schwarz U, Teschner M, Hammer B, Schmelzeisen R. Manufacturing splints for orthognathic surgery using a three-dimensional printer. Oral Surg Oral Med Oral Pathol Oral Radiol Endod. 2008 Feb;105(2):e1-7. doi: 10.1016/j.tripleo.2007.07.040.

Moerenhout BA, Gelaude F, Swennen GR, Casselman JW, Van Der Sloten J, Mommaerts MY. Accuracy and repeatability of cone-beam computed tomography (CBCT) measurements used in the determination of facial indices in the laboratory setup. J Craniomaxillofac Surg. 2009 Jan;37(1):18-23. doi: 10.1016/j.jcms.2008.07.006. Epub 2008 Sep 23.

Noh H, Nabha W, Cho JH, Hwang HS. Registration accuracy in the integration of laser-scanned dental images into maxillofacial cone-beam computed tomography images. Am J Orthod Dentofacial Orthop. 2011 Oct;140(4):585-591. doi: 10.1016/j.ajodo.2011.04.018.

Nunes LS, Bornstein MM, Sendi P, Buser D. Anatomical characteristics and dimensions of edentulous sites in the posterior maxillae of patients referred for implant therapy. Int $\mathbf{J}$ Periodontics Restorative Dent. 2013 May-Jun;33(3):337-345. doi: 10.11607/prd.1475.

Ogawa T, Ogimoto T, Koyano K. Validity of the examination method of occlusal contact pattern relating to mandibular position. J Dent. 2000 Jan;28(1):23-29.

Paquette DE. Importance of the occlusal plane in virtual treatment planning. J Clin Orthod. 2011 Apr;45(4):217-221; quiz 236. 
Parbatani R, Williams AC, Ireland AJ, Sandy J. The process of orthognathic care in an NHS region. Ann $\mathrm{R}$ Coll Surg Engl. 2010 Jan;92(1):34-39. doi: 10.1308/003588410X12518836438723. Epub 2009 Nov 2.

Ribas GC, Bento RF, Rodrigues AJ Jr. Anaglyphic three-dimensional stereoscopic printing: revival of an old method for anatomical and surgical teaching and reporting. J Neurosurg. 2001 Dec;95(6):1057-1066.

Sarver DM. Video imaging a computer facilitated approach to communication and planning in orthognathic surgery. Br J Orthod. 1993 Aug;20(3):187-191.

Schroeder WJ, Zarge JA, Lorensen WE. Decimation of Triangle Meshes 1992 Jul; 26(2):6570.

Schutyser F, Swennen G, Suetens P. Robust visualization of the dental occlusion by a double scan procedure. Med Image Comput Comput Assist Interv. 2005;8(Pt 1):368-374.

Smith BGN. Occlusion: 1. General Considerations. Dent Update 1991;18:141-145.

Swennen GR, Mollemans W, Schutyser F. Three-dimensional treatment planning of orthognathic surgery in the era of virtual imaging. J Oral Maxillofac Surg. 2009 Oct;67(10):2080-2092. doi: 10.1016/j.joms.2009.06.007. Erratum in: J Oral Maxillofac Surg. 2009 Dec;67(12):2703.

Swennen GR, Mommaerts MY, Abeloos J, De Clercq C, Lamoral P, Neyt N, Casselman J, Schutyser F. A cone-beam CT based technique to augment the 3D virtual skull model with a detailed dental surface. Int J Oral Maxillofac Surg. 2009 Jan;38(1):48-57. doi: 10.1016/j.ijom.2008.11.006. Epub 2008 Dec 31. PubMed PMID: 19118978.

Tahmaseb A, Wismeijer D, Coucke W, Derksen W. Computer technology applications in surgical implant dentistry: a systematic review. Int J Oral Maxillofac Implants. 2014;29 Suppl:25-42. doi: 10.11607/jomi.2014suppl.g1.2. 
Taubin G. Curve and surface smoothing without shrinkage. ICCV 1995 Jun;852-857.

Trefný P, Tauferová E, Bálková S. Three-dimensional visualisation and analysis of postoperative changes in the size and shape of the dental arch and palate. Acta Chir Plast. 2005;47(4):124-128.

Varga E Jr, Hammer B, Hardy BM, Kamer L. The accuracy of three-dimensional model generation. What makes it accurate to be used for surgical planning? Int J Oral Maxillofac Surg. 2013 Sep;42(9):1159-1166. doi: 10.1016/j.ijom.2013.02.006. Epub 2013 Mar 21.

Watamoto T, Egusa H, Mizumori T, Yashiro K, Takada K, Yatani H. Restoration of occlusal and proximal contacts by a single molar crown improves the smoothness of the masticatory movement. J Dent. 2008 Dec;36(12):984-992. doi: 10.1016/j.jdent.2008.08.005. Epub 2008 Sep 14 .

$\mathrm{Xu}$ M, Yang F, Wang RF. [Cone-beam CT analysis of human maxillary sinus: anatomical considerations for sinus augmentation and implant insertion]. Shanghai Kou Qiang Yi Xue. 2011 Apr;20(2):187-190. 
VIII. Appendix (Personal paper reprints) 


\section{Elsevier Editorial System(tm) for International Journal of Oral \& Maxillofacial Surgery}

Manuscript Draft

\section{Manuscript Number:}

Title: 3D modeling of the occlusal surface. What makes it accurate to be used for surgical planning?

Article Type: Original Article

Keywords: 3D computer model, accuracy, dental imaging, imaging modalities, imaging procedures, dental occlusion, computer tomograph

Corresponding Author: Dr. Endre Varga, D.M.D.

Corresponding Author's Institution:

First Author: Endre Varga, Dr. Med. Dent.

Order of Authors: Endre Varga, Dr. Med. Dent.; Beat Hammer, Dr. Med, Dr. Med. Dent.; Benjamin M Hardy; Lukas Kamer, Dr. Med, Dr. Med. Dent.

Abstract: Physical models of the dental occlusion, such as dental plaster cast models, are routinely used in dental and in cranio-maxillofacial applications. For treatment planning and therapeutic applications, it is of critical importance to have a precise model of the structures in question. Improved imaging techniques and advances in software engineering have moved three-dimensional (3D) computer models from the research and development area into routine clinical application. The importance of high-resolution source imagery is well understood by surgeons. The influence of image processing in model generation is poorly understood in the surgical community and we hypothesize that this may be a source of significant error. In this paper, we evaluate the workflow for creating a virtual dental model using CT data and the impact that image processing decisions have on final virtual model accuracy. Individual image processing steps are explained and the magnitudes of their influence on model quality are demonstrated and compared. This study demonstrates that inappropriate image processing can introduce errors of similar magnitude as the use of inadequate source data. Finally, the study demonstrates that errors caused by inappropriate image processing amplify the inaccuracies of lowresolution source imagery and eliminate the benefits of high-resolution source imagery. 


\section{Declarations}

The following additional information is required for submission. Please note that failure to respond to these questions/statements will mean your submission will be returned to you. If you have nothing to declare in any of these categories then this should be stated.

Please state any conflict of interests. A conflict of interest exists when an author or the author's institution has financial or personal relationships with other people or organisations that inappropriately influence (bias) his or her actions. Financial relationships are easily identifiable, but conflicts can also occur because of personal relationships, academic competition, or intellectual passion. A conflict can be actual or potential, and full disclosure to The Editor is the safest course.

\section{Competing Interests}

None declared

Please state any sources of funding for your research

Funded by the AOCMF Specialty of the AO Foundation, Davos Switzerland (AOCMF Research Grant C-10-25Z)

Please state whether Ethical Approval was given, by whom and the relevant Judgement's reference number

Not required

This information must also be inserted into your manuscript under the acknowledgements section prior to the References. If you have no declaration to make please insert the following statements into your manuscript:

Competing interests: None declared 
Funding: None

Ethical approval: Not required 
3D modeling of the occlusal surface. What makes it accurate to be used for surgical planning?

Authors:

Endre Varga $\mathrm{Jr}^{1}$

Beat Hammer ${ }^{2}$

Benjamin M Hardy ${ }^{3}$

Lukas Kamer $^{1}$

1: AO Research Institute, Davos, Switzerland

2: cfc hirslanden Cranio Facial Centrer, Hirslanden Medical Center, Aarau, Switzerland

3: University of Newcastle, New South Wales, Australia

Institution:

AO Research Institute, Davos

Clavadelerstrasse 8

7270 Davos Platz

Switzerland

Responsible author:

Endre Varga DMD

AO Research Institute, Davos

Clavadelerstrasse 8

7270 Davos Platz

Switzerland

Mobile: +36 305020368

Email: endrevargadmd@yahoo.com

Keywords: 
3D computer model, accuracy, dental imaging, imaging modalities, imaging procedures, dental occlusion, computer tomograph 
Abstract

Physical models of the dental occlusion, such as dental plaster cast models, are routinely used in dental and in cranio-maxillofacial applications. For treatment planning and therapeutic applications, it is of critical importance to have a precise model of the structures in question. Improved imaging techniques and advances in software engineering have moved threedimensional (3D) computer models from the research and development area into routine clinical application. The importance of high-resolution source imagery is well understood by surgeons. The influence of image processing in model generation is poorly understood in the surgical community and we hypothesize that this may be a source of significant error. In this paper, we evaluate the workflow for creating a virtual dental model using CT data and the impact that image processing decisions have on final virtual model accuracy. Individual image processing steps are explained and the magnitudes of their influence on model quality are demonstrated and compared. This study demonstrates that inappropriate image processing can introduce errors of similar magnitude as the use of inadequate source data. Finally, the study demonstrates that errors caused by inappropriate image processing amplify the inaccuracies of low-resolution source imagery and eliminate the benefits of high-resolution source imagery. 
Introduction

Physical models of the dental occlusion, such as dental plaster cast models, are routinely used in dental and in cranio-maxillofacial applications. For treatment planning and therapeutic applications, it is of critical importance to have a precise model of the structures in question. This is especially important with regard to the occlusal surfaces and to the interocclusal relationship between upper and lower jaw $^{1-5}$.

Advanced imaging techniques, software and computerized manufacturing techniques have made three-dimensional (3D) computer models available not only for research and development, but also for routine clinical applications ${ }^{6-8}$. They could potentially replace classical plaster models allowing new options for occlusal analysis and treatment workflows ${ }^{9-11}$. The generation of a virtual model requires imaging and subsequent image processing steps. Image capture is performed by scanning of the patient's occlusion directly or of a plaster cast using either tomographic imaging modalities or optical surface scanning. The image data is then computed to produce a 3D visualization.

Computed Tomography (CT) or Cone Beam Computed Tomography (CBCT) imaging captures a consecutive series of 2D images, containing digitized tissue densities of the scanned slice. The data stack is stored as single image slices in DICOM format (Digital Imaging and Communication in Medicine) $)^{12-16}$.

Optical surface scanning captures 3D surface information via generation of a point cloud, rather than the interpolation of tissue densities. These points are extrapolated to a 3D surface mesh to form the shape of an object ${ }^{17}$. In contrast to CT or CBCT, optical scanning only captures surface contours, without any subsurface detail. In both X-ray based imaging and optical surface scanning the final result is a 3D surface mesh of the imaged structure. The surface meshes can be than merged together to create a composite skull model ${ }^{18,19}$. This technique relies on both the accuracy of the models and the precision of the incorporation procedures.

When considering a virtual model, the clinician must be aware of the need for adequate source imaging and the image processing steps required to create the final model. Some of these steps are performed by user interaction while some are "hidden" procedures within the software. The 
impact of the image processing steps may subtly influence the accuracy of the final model. G The generation of a virtual model from either $2 \mathrm{D}$ or $3 \mathrm{D}$ data is based on well-established imaging and image processing techniques. However, models of dental occlusion demands previously impossible levels of precision and accuracy. Surgical planning requires models of sufficient detail to enable the virtual plan to perform well when put into reality. Inadequate models may result in misleading patient assessment, inappropriate treatment and unsatisfactory clinical outcome. Conversely, accurate virtual occlusion modeling may enable more efficient and effective workflows for patient assessment and treatment.

The objective of this study was to evaluate the impact of different imaging modalities and image processing steps on the accuracy of the resulting virtual occlusion model, and to identify and quantify the most critical steps to ensure accurate model generation. Further goals were to educate clinicians of the implications of these computational procedures and to discuss the clinical impact of the results. We report on the use of high resolution CBCT imaging, and on image processing parameters relevant to creating an accurate virtual model of the occlusal surface.

Material and Methods

\section{IMAGE ACQUISITION}

A standard dental plaster model was scanned using an experimental high resolution CBCT scanner (Scanco SCANCO Medical AG Brüttisellen, Switzerland) with an isotropic image resolution of $0.082 \mathrm{~mm}$ using standard CBCT image acquisition parameters $(60 \mathrm{kVp} / 40 \mathrm{keV}$ $(900 \mu \mathrm{A}))$. The DICOM information were transferred to a desktop computer running Windows XP (Microsoft Corporation, Redmond, CA) and post-processed in Amira ${ }^{\circledR}$, a commercial software package for image visualization and data analysis (Visage Imaging $\mathrm{GmbH}$, Berlin, Germany), and Geomagic Studio®, a reverse engineering software package (Geomagic U.S. Corp., Research Triangle Park, USA). 
The workflow for creating a virtual model was evaluated using the CBCT data and divided into six major image processing steps. The first three steps, evaluating the impact of the (1) image resolution, (2) thresholding procedure, and (3) smoothing of the labeled threshold data, are performed on the 2D CT data before surface model generation as presented in Fig. 1. Then a 3D triangulated surface model was generated to evaluate the effect of (4) different model generation techniques, (5) smoothing the surface model and (6) reducing the number of triangles of the surfaces shown in Fig 1 and 2.

Step 1 - Image resolution.

A gold standard (GS) CT scan was captured with a $0.82 \mathrm{~mm}$ resolution. To simulate lower resolution $\mathrm{CT}$ acquisition, the gold standard image data stack was duplicated and down-sampled to a variety of resolutions of interest. A total of 8 downsampling procedures were used to produce the following different image resolutions: 4 copies were down-sampled in an isotropic manner to represent an image resolution of $0.1 \mathrm{~mm}$ to $0.4 \mathrm{~mm}$. A further 4 datasets were downsampled to represent non-isotropic scanning, all having the same image resolution of $0.4 \mathrm{~mm}$ in the $\mathrm{x}$ and $\mathrm{y}$ axes but varying image resolutions ranging from $0.4 \mathrm{~mm}$ to $0.8 \mathrm{~mm}$ in the $\mathrm{z}$ axis.

Duplication and downsampling of the models was used to simulate the lower resolution imaging capture rather that scanning at lower resolution. Simulation eliminated the introduction of error due to malpositioning of the real-world model during repeated scanning at differing resolutions. This standardization meant that all deviations from the gold standard could be reliably attributed to image processing steps, rather than errors in acquisition.

From each 2D image stack, an unsmoothed model was generated using the LegoSurfaceGen procedure within Amira®. For each model an identical threshold window setting of 1421 6950 was chosen and the Amira's LegoSurfaceGen applied. The end result of this procedure was 8 virtual models of the same physical object generated from the source image data of varying resolution. Each model was then compared with the the gold standard model using the distance map calculation and visualization procedure in Geomagic ${ }$. The distance map procedure calculated the differences between the gold standard and the downsampled model. 
Distance mapping allows calculation of maximum and mean differences between the two models. (Fig 1 A, B)

Step 2 - Threshold segmentation.

This procedure is used to convert the continuous greyscale 2D CT data into a binary representation of which pixels of CT data represent the surface of the model being generated. A low (inclusive) threshold value of 990-6950 and a high (exclusive) one of 1914-6950 were defined. For each of the varying resolution CT scans generated in step 1, two additional models were generated using a high and low threshold and the LegoSurfaceGen procedure. For each resolution, the high and low threshold models were separately compared with the medium threshold model of the identical resolution generated in step 1. This enables the assessment of the impact of the threshold procedure, without the influence of image resolution. The deviations between the models were calculated using Geomagic's distance map calculation and visualization. (Fig $1 \mathrm{C}, \mathrm{D})$

Step 3 - Smoothing 2D CT data.

A predefined smoothing procedure was applied to the 2D CT data using the 'smooth label' function (Parameters: size 5) in the Amira segmentation editor. A LegoSurfaceGen model was created from each of the smoothed 2D CT datasets. The deviations between the models were compared with the models of corresponding resolution obtained in step 1, using Geomagic's distance map calculation and visualization. (Fig 1 E, F)

Step 4 - 3D model generation using the Marching Cube Algorithm.

For each of the resolutions established in step 1, a model was created using Amira's standard SurfaceGen module, rather than LegoSurfaceGen. The SurfaceGen procedure creates meshed surface models according to the Marching cubes algorithm, smoothing the voxel structure into a triangulated meshed surface topology. The deviations between the SurfaceGen model and the identical resolution LegoSurfaceGen models obtained in step 1 were compared using Geomagic's distance map calculation and visualization. (Fig 2 A, B) 
Step 5 - Smoothing of generated 3D models.

Two different smoothing settings were chosen in Geomagic for each model obtained in step 4: Setting 1 corresponding to moderate smoothing ("smoothness level" to a low level " 3 " and "Curvature priority" to a high level "8") and setting 2 corresponding to extensive smoothing ("smoothness level" to a high level "8" and "Curvature priority" to a low level "3"). For each resolution, the models with moderate and extensive smoothing were separately compared with the original unsmoothed model of identical resolution generated in step 4 . The differences between models were analyzed using Geomagic's distance map calculation and visualization. (Fig 2 C, D)

Step 6 - Reducing the number of the mesh triangles.

In the eight surface models generated in step 4 the number of the mesh triangles were calculated in Geomagic. The number of triangles for each model were reduced by $50 \%$ to represent a common complexity reduction procedure performed in model generation workflows. For each resolution, the resulting simplified model was compared with the identical resolution model obtained in assessment 4. The differences between models were analyzed using Geomagic's distance map calculation and visualization. (Fig 2 E, F)

Results:

The impact of CT scan resolution and the 5 subsequent workflow steps were assessed. (Table 1, Fig 3)

\section{Resolution}

Beginning with the highest resolution, the data revealed a linear increase in the deviations between the models generated from reduced resolution CT scans and the gold standard model. In the non-isotropic image resolution part (i.e. from 0.5 to $0.8 \mathrm{~mm}$ ) there was a less steep slope, compared to the isotropic part. For each image resolution, the max+/max- values showed similar 
absolute deviation values. Between the highest and lowest resolution, there was a four-fold increase of the deviation, with maximum absolute values of about $0.45 \mathrm{~mm}$ (corresponding to $+0.438 /-0.492 \mathrm{~mm})$. The distance maps demonstrated a uniform deviation pattern on the occlusal surfaces, when compared with the GS. (Fig 3, Step 1)

\section{2a. Threshold segmentation with low threshold value}

The data showed the maximum deviation in the positive direction from the corresponding resolution GS (CGS) increased as CT resolution decreased in models with isotropic voxels, and did not change in models with non-isotropic voxels. The max+ and max- values showed different absolute values. The max- values showed an approximately linear increase up to $0.8 \mathrm{~mm}$, regardless of model isotropy. The max + values showed as similar increase from 0.1 to $0.4 \mathrm{~mm}$, but afterwards the values remained virtually unchanged, between the $0.4,0.5,0.6,0.7$ and $0.8 \mathrm{~mm}$ resolution $\mathrm{CT}$ scans.

2b. Threshold segmentation with high threshold value

The data illustrated the maximum deviations from the CGS in the positive directions increasing linearly as CT resolution was decreased. The maximum negative deviation increased with decreasing resolution in the models with isotropic voxels, but did not change significantly with the non-isotropic voxels. This is the inverse of the results described in section $2 \mathrm{a}$. The max+ exhibits a linear increase up to $0.8 \mathrm{mmm}$ and the max- values remained stable at resolutions above $0.4 \mathrm{~mm}$.

In both assessment $2 \mathrm{a}$ and $2 \mathrm{~b}$, the distance maps show a uniform deviation pattern within the overall occlusal surface, when compared with the CGS.

\section{Smoothing 2D CT data}

The data displayed a linear increase in model deviation as CT resolution was reduced. In contrast to assessment (1), (2a) and (2b) this smoothing procedure lead to a characteristic change in the surface topology of the occlusal surface with loss of areas with small-radius curvatures. The loss of details in area of tight curvature lead to a flattening of the occlusal cusps 
(thus reducing the height of the occlusal cusps) and of the occlusal fissures (thus filling the occlusal fissures), leading to an overall flattening of the occlusal surface topology as shown on the distance maps in Fig. 4.

4. Model generation using the Marching Cubes algorithm Among both for the max+ and max- values, there was a linear increase in deviation from the CGS until $0.4 \mathrm{~mm}$ image resolution. The rate of deviation accelerated at lower resolutions than $0.4 \mathrm{~mm}$. Large deviations were observed for values at a non-isotropic image resolution of 0.7 and $0.8 \mathrm{~mm}$, deviating $>1.6 \mathrm{~mm}$ from the CGS. The Marching Cubes Algorithm resulted in a similar non-uniform change in the surface topology, as observed in (3).

5a. Smoothing on generated surface models with moderate settings

The data demonstrated linear growth in deviation until the $0.4 \mathrm{~mm}$ resolution group, and then ceased to change. This procedure did not change the max values. Maximum deviations approached $0.12 \mathrm{~mm}$.

5b. Smoothing on generated surface models with extensive settings

The data displayed growth in deviation. In contrast to 5a, when using these settings the max+ increased with lower image resolution. At the non isotropic level of 0.7 and 0.8 the max+ deviation reached up to $1.6 \mathrm{~mm}$.

6. Reducing the number of the triangles

Reducing the triangle number by $50 \%$ did not change the max+ deviations. Below a CT resolution of $0.3 \mathrm{~mm}$, the reduction in model complexity lead to deviations by between 0.1 and $0.2 \mathrm{~mm}$.

Discussion 
The objective of this study was to assess the impact of the different imaging modalities and different image processing steps on the accuracy of a virtual occlusion model and to guide clinicians to understanding the most critical steps for accurate model generation. The following image processing steps were assessed: image resolution, manual threshold segmentation, smoothing the labeled threshold data, the Marching Cubes algorithm ${ }^{20,21}$. smoothing of the surface mesh $^{22,23}$ and the number of meshes ${ }^{24,25,26}$. Intuitively resolution is the essence of an accurate model. No image processing step can compensate for lack of resolution in the original data. Inadequate resolution amplifies the negative effects of image processing. However, image processing can severely degrade the quality of a model generated from high-resolution data. The evaluations shows that each processing step effects the quality and accuracy of the 3D model. Each step is dependent on the image processing techniques chosen in previous steps. Errors introduced early in the workflow are multiplied by subsequent image processing steps. Particularly, early decisions made during manipulation of label field data in 2D scans have a dramatic effect on final model accuracy.

The usage of virtual 3D models for treatment planning and computer aided surgery (CAS) systems has several advantages. Virtual treatment planning can make surgeries less invasive, operating time shorter and post operative outcome more accurate. This technique relies on the accuracy of the virtual model to ensure a successful surgery. Models produced from highresolution source data can appear accurate on superficial inspection, despite key inaccuracies introduced by image processing. Clinicians planning surgery with virtual models must be familiar with each step of the workflow. The production of accurate 3D models from imaging data requires specific knowledge of the techniques involved.

The study demonstrates that there are two distinct classes of errors introduced by image processing. One class makes uniform change to the entire occlusal surface, making it smaller or bigger. The other alters the surface topology in a non-uniform manner, particularly impacting areas of high geometric complexity. Both effects lead to inaccuracies in virtual model generation. 
A potentially satisfactory alternative to $3 \mathrm{D}$ model generation from CT data is optical scanning of dental structures. Use of this technique does not escape the need for CT in many cases, nor does it eliminate accuracies from 3D model image processing If detail of the underlying structures is needed for surgical planning, CT scanning is still required, as is often the case in orthognatic and surgical procedures affecting dental structures. An additional source of error within optical scanning is the merging and alignment of CT-derived and optical scan-derived model data. Finally, models generated from optical surface scanning must still undergo image processing of the 3D model, potentially introducing the inaccuracies detailed in this study.

In conclusion, accurate 3D models require a combination of appropriate resolution imaging and image processing. The importance of resolution in the source imaging is well understood by surgeons. The critical nature of image processing is poorly recognized and this study demonstrates it as a source of significant error. Adequate quality models can be produced using average resolution CT scanners as long as the importance of image processing is understood. The operator must understand the implications of each step of the model creation workflow to ensure their model truly reflects reality. 
Acknowledgements

The authors are grateful to Hansruedi Noser, Thomas Heldstab, Balázs Erdőhelyi and Nicole Haldi for their valuable support for the project.

Special thanks to Geoff R Richards for the AO fellowship.

This research project was supported by the AOCMF Specialty of the AO Foundation. (AOCMF Research Grant C-10-25Z) 


\section{References}

1. Jacobs R. Dental cone beam CT and its justified use in oral health care.

JBR-BTR. 2011 Sep-Oct: 94(5):254-65.

2. Ogawa T, Ogimoto T, Koyano K. Validity of the examination method of occlusal contact pattern relating to mandibular position. J Dent. 2000 Jan: 28(1):23-9.

3. Paquette DE. Importance of the occlusal plane in virtual treatment planning. J Clin Orthod. 2011 Apr: 45(4):217-21

4. Watamoto T, Egusa H, Mizumori T, Yashiro K, Takada K, Yatani H. Restoration of occlusal and proximal contacts by a single molar crown improves the smoothness of the masticatory movement. J Dent. 2008 Dec: 36(12):984-92.

5. Smith BGN. Occlusion: 1. General Considerations. Dent Update 1991: 18: 141-145.

6. Trefný P, Tauferová E, Bálková S. Three-dimensional visualisation and analysis of post-operative changes in the size and shape of the dental arch and palate. Acta Chir Plast. 2005: 47(4):124-8.

7. Marchetti C, Bianchi A, Bassi M, Gori R, Lamberti C, Sarti A. Mathematical modeling and numerical simulation in maxillo-facial virtual surgery (VISU). $\mathrm{J}$ Craniofac Surg. 2006 Jul: 17(4):661-7; discussion 668.

8. Schutyser F, Swennen G, Suetens P. Robust visualization of the dental occlusion by a double scan procedure. Med Image Comput Comput Assist Interv. 2005: 8(Pt 1):368-74.

9. Favero L, Terrazzani C, Favero V, Stellini E, Cocilovo F. Virtual study models: a comparison of modular application systems. Prog Orthod. 2009: 10(2):16-25.

10. Plooij JM, Maal TJ, Haers P, Borstlap WA, Kuijpers-Jagtman AM, Bergé SJ. Digital three-dimensional image fusion processes for planning and evaluating orthodontics and orthognathic surgery. A systematic review. Epub 2010 Nov 20. Review. 
orthognathic surgery in the era of virtual imaging. J Oral Maxillofac Surg. 2009

Oct: 67(10):2080-92.

12. Hounsfield GN. Computed medical imaging. Science. 1980 Oct 3: 210(4465):22-8.

Review.

13. De Vos W, Casselman J, Swennen GR. Cone-beam computerized tomography (CBCT) imaging of the oral and maxillofacial region: a systematic review of the literature. Int J Oral Maxillofac Surg. 2009 Jun: 38(6):609-25.

14. Jahne B: Digital image processing. Springer. 1991 nov. 28.

15. Pratt WK: Digital image processing. John Wiley and sons, New York 1991.

16. Loubele M, Maes F, Schutyser F, Marchal G, Jacobs R, Suetens P. Assessment of bone segmentation quality of cone-beam CT versus multislice spiral CT: a pilot study. Oral Surg Oral Med Oral Pathol Oral Radiol Endod. 2006 Aug: 102(2):225-34. Epub 2006 Apr 21.

17. Moerenhout BA, Gelaude F, Swennen GR, Casselman JW, Van Der Sloten J, Mommaerts MY. Accuracy and repeatability of cone-beam computed tomography (CBCT) measurements used in the determination of facial indices in the laboratory setup. J Craniomaxillofac Surg. 2009 Jan: 37(1):18-23.

18. Gateno J, Xia J, Teichgraeber JF, Rosen A. A new technique for the creation of a computerized composite skull model. J Oral Maxillofac Surg. 2003

Feb: 61(2):222-7.

19. Noh H, Nabha W, Cho JH, Hwang HS. Registration accuracy in the integration of laser-scanned dental images into maxillofacial cone-beam computed tomography images. Am J Orthod Dentofacial Orthop. 2011 Oct: 140(4):585-91.

20. Harvey E. Cline, William E. Lorensen System and method for the display of surface structures contained within the interior region of a solid body. 1987 Dec: Patent Number: 4710876 
21. Lorensen WE, Cline HE: Marching cubes: A high resolution 3D surface construction algorithm. Computer Graphics. 1987: Vol. 21, No. 4, pp. 163-169.

22. Belyaev A: A Comparison of Mesh Smoothing Methods. Computer. 2003: (2): 1-5.

23. Taubin G: Curve and surface smoothing without shrinkage. ICCV. 1995: 852-857

24. Luebke DP: A Developer's Survey of Polygonal Simplification Algorithms. IEEE. 2001 May-Jun: (21): 24-35.

25. Garland M, Heckbert PS: Surface simplification using quadric error metrics. ACM. 1997: 209-216.

26. Schroeder WJ, Zarge JA, Lorensen WE: Decimation of Triangle Meshes. 1992: 65-70. 
Fig. 1. Image processing steps performed on 2D CT data.

The first line shows the impact of image resolution (A: $0.1 \mathrm{~mm}$ voxel size, B: $0.8 \mathrm{~mm}$ non isotropic).

Second line highlights the threshold segmentation (C: high, exclusive-, and D: low, inclusive settings, Resolution: $0.1 \mathrm{~mm})$.

Third line demonstrates the smoothing procedure (E: without smoothing, F: smoothed border line, Resolution: $0.3 \mathrm{~mm}$ )

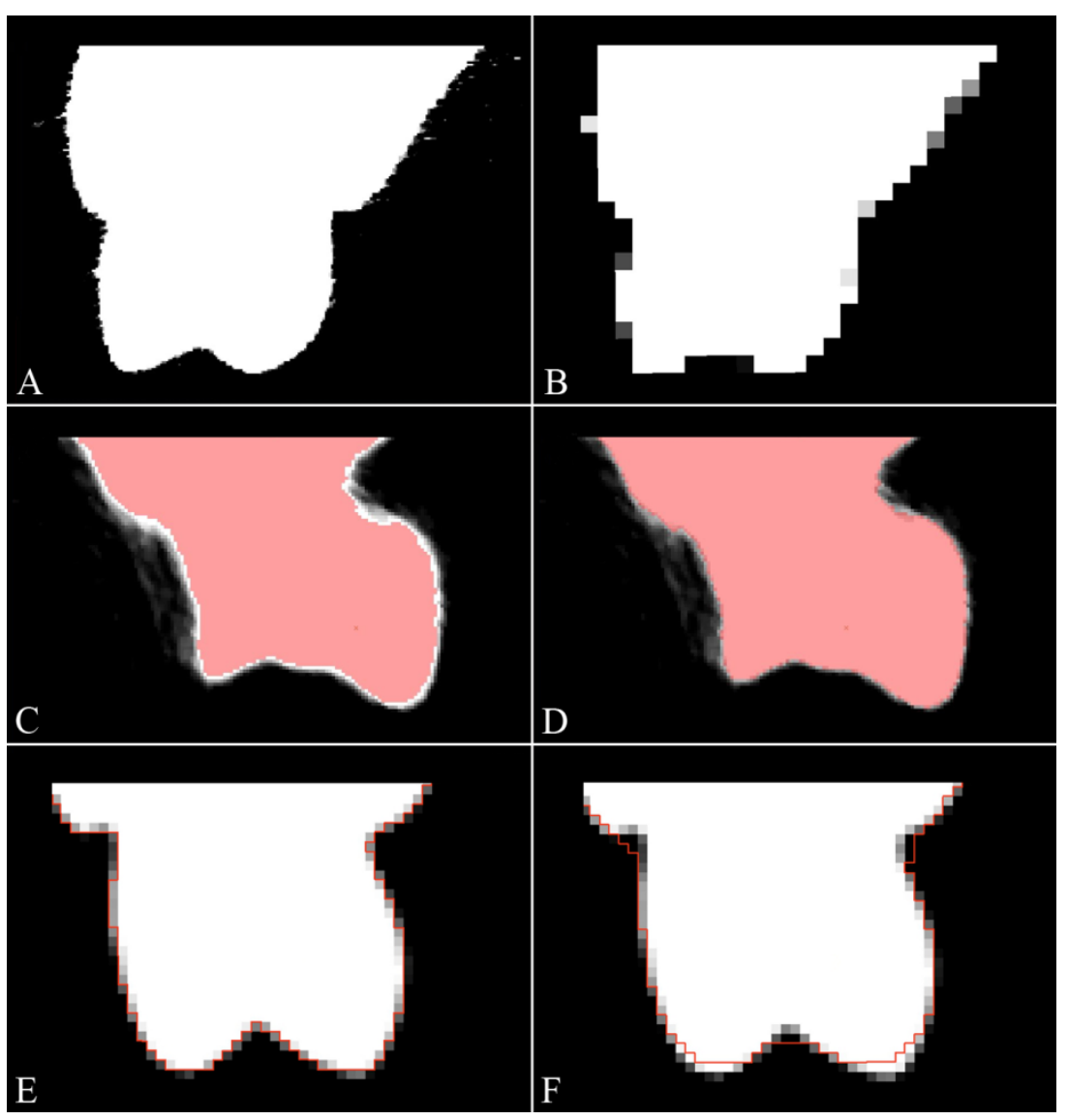


Fig. 2. The effects of image processing steps made on 3D data.

First line shows the effect of 3D model generation from 2D data with different algorithms (A:

LegoSurfaceGen, B: Marching Cubes Algorithm, Resolution: 0.4mm)

Effects of smoothing the 3D surface is visualized in the second line (C: moderate-, D: extensive smoothing, Resolution: $0.3 \mathrm{~mm}$ )

Third line presents the result of reducing the number of the surface triangles (E: 41000 triangles, F: 20500 triangles, Resolution $0.4 \mathrm{~mm})$

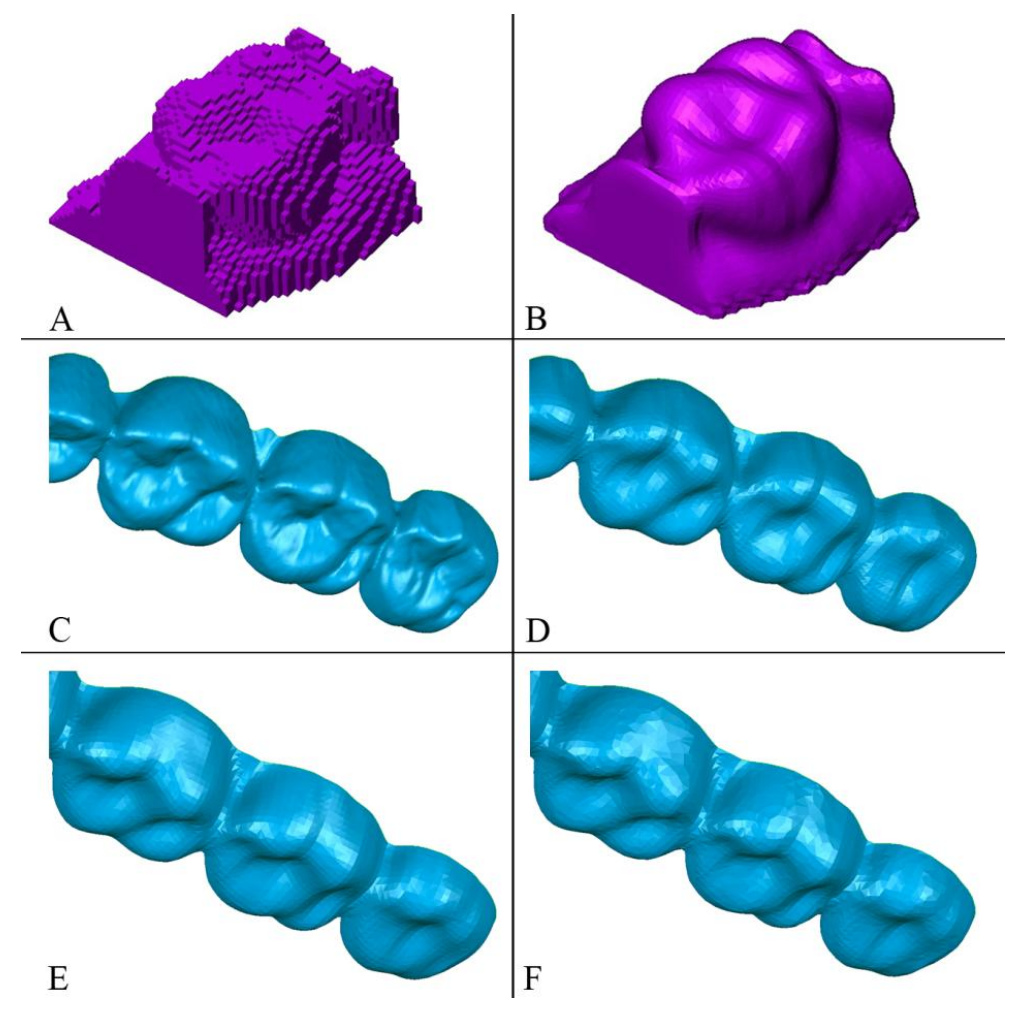


Table 1. Deviations in all steps and their corresponding resolution (mm).

\begin{tabular}{|c|c|c|c|c|c|c|c|c|}
\hline Step 1 & 0.1 & 0.2 & 0.3 & 0.4 & $0.5(0.4)$ & $0.6(0.4)$ & $0.7(0.4)$ & $0.8(0.4)$ \\
\hline Max+ & 0.078 & 0.158 & 0.216 & 0.292 & 0.322 & 0.354 & 0.402 & 0.438 \\
\hline$\overline{\text { Max- }}$ & -0.08 & -0.145 & -0.22 & -0.324 & -0.335 & -0.382 & -0.444 & -0.492 \\
\hline Average+ & 0.021 & 0.035 & 0.053 & 0.071 & 0.082 & 0.09 & 0.103 & 0.117 \\
\hline Average- & -0.021 & -0.037 & -0.055 & -0.077 & -0.085 & -0.097 & -0.113 & -0.127 \\
\hline$\overline{\mathrm{SD}}$ & 0.026 & 0.045 & 0.067 & 0.092 & 0.104 & 0.117 & 0.135 & 0.153 \\
\hline Step 2a & 0.1 & 0.2 & 0.3 & 0.4 & $0.5(0.4)$ & $0.6(0.4)$ & $0.7(0.4)$ & $0.8(0.4)$ \\
\hline$\overline{\operatorname{Max}}+$ & 0.136 & 0.2 & 0.29 & 0.393 & 0.4 & 0.433 & 0.4 & 0.42 \\
\hline Max- & -0.2 & -0.245 & -0.3 & -0.4 & -0.5 & -0.6 & -0.7 & -0.8 \\
\hline Average+ & 0.001 & 0.004 & 0.004 & 0.003 & 0.004 & 0.004 & 0.006 & 0.005 \\
\hline Average- & -0.037 & -0.044 & -0.053 & -0.061 & -0.065 & -0.073 & -0.058 & -0.086 \\
\hline$\overline{S D}$ & 0.033 & 0.052 & 0.068 & 0.082 & 0.091 & 0.098 & 0.099 & 0.11 \\
\hline Step 2b & 0.1 & 0.2 & 0.3 & 0.4 & $0.5(0.4)$ & $0.6(0.4)$ & $0.7(0.4)$ & $0.8(0.4)$ \\
\hline Max+ & 0.136 & 0.2 & 0.3 & 0.4 & 0.5 & 0.6 & 0.7 & 0.8 \\
\hline Max- & -0.104 & -0.2 & -0.291 & -0.397 & -0.4 & -0.462 & -0.4 & -0.548 \\
\hline Average+ & 0.031 & 0.04 & 0.047 & 0.058 & 0.065 & 0.006 & 0.098 & 0.078 \\
\hline Average- & 0 & -0.003 & -0.003 & -0.003 & -0.004 & -0.004 & -0.005 & -0.006 \\
\hline$\overline{S D}$ & 0.031 & 0.05 & 0.066 & 0.086 & 0.093 & 0.099 & 0.104 & 0.112 \\
\hline Step 3 & 0.1 & 0.2 & 0.3 & 0.4 & $0.5(0.4)$ & $0.6(0.4)$ & $0.7(0.4)$ & $0.8(0.4)$ \\
\hline Max+ & 0.166 & 0.297 & 0.404 & 0.518 & 0.617 & 0.73 & 0.779 & 0.828 \\
\hline Max- & -0.152 & -0.318 & -0.479 & -0.741 & -0.818 & -0.833 & -0.904 & -0.978 \\
\hline Average+ & 0.018 & 0.042 & 0.074 & 0.107 & 0.11 & 0.117 & 0.12 & 0.122 \\
\hline Average- & -0.024 & -0.063 & -0.121 & -0.197 & -0.223 & -0.248 & -0.27 & -0.284 \\
\hline$\overline{\mathrm{SD}}$ & 0.026 & 0.066 & 0.117 & 0.176 & 0.192 & 0.206 & 0.223 & 0.24 \\
\hline Step 4 & 0.1 & 0.2 & 0.3 & 0.4 & $0.5(0.4)$ & $0.6(0.4)$ & $0.7(0.4)$ & $0.8(0.4)$ \\
\hline$\overline{\operatorname{Max}+}$ & 0.129 & 0.214 & 0.31 & 0.398 & 0.461 & 0.456 & 0.771 & 1.329 \\
\hline Max- & -0.1 & -0.227 & -0.347 & -0.472 & -0.534 & -0.573 & -0.666 & -0.743 \\
\hline Average+ & 0.017 & 0.034 & 0.055 & 0.077 & 0.084 & 0.101 & 0.125 & 0.155 \\
\hline Average- & -0.02 & -0.046 & -0.08 & -0.124 & -0.139 & -0.153 & -0.171 & -0.187 \\
\hline$\overline{S D}$ & 0.022 & 0.049 & 0.083 & 0.121 & 0.133 & 0.15 & 0.177 & 0.208 \\
\hline Step 5a & 0.1 & 0.2 & 0.3 & 0.4 & $0.5(0.4)$ & $0.6(0.4)$ & $0.7(0.4)$ & $0.8(0.4)$ \\
\hline Max+ & 0.015 & 0.052 & 0.076 & 0.12 & 0.12 & 0.11 & 0.129 & 0.122 \\
\hline Average+ & 0.001 & 0.002 & 0.005 & 0.008 & 0.009 & 0.009 & 0.01 & 0.012 \\
\hline$\overline{\mathrm{SD}}$ & 0.001 & 0.003 & 0.007 & 0.01 & 0.012 & 0.012 & 0.014 & 0.015 \\
\hline Step 5b & 0.1 & 0.2 & 0.3 & 0.4 & $0.5(0.4)$ & $0.6(0.4)$ & $0.7(0.4)$ & $0.8(0.4)$ \\
\hline$\overline{\operatorname{Max}+}$ & 0.249 & 0.515 & 0.804 & 1.095 & 1.244 & 1.43 & 1.626 & 1.642 \\
\hline Average+ & 0.051 & 0.153 & 0.271 & 0.39 & 0.419 & 0.442 & 0.46 & 0.486 \\
\hline$\overline{\mathrm{SD}}$ & 0.0376 & 0.098 & 0.173 & 0.254 & 0.28 & 0.302 & 0.328 & 0.346 \\
\hline Step 6 & 0.1 & 0.2 & 0.3 & 0.4 & $0.5(0.4)$ & $0.6(0.4)$ & $0.7(0.4)$ & $0.8(0.4)$ \\
\hline$\overline{M a x}+$ & 0.006 & 0.045 & 0.115 & 0.074 & 0.088 & 0.152 & 0.091 & 0.175 \\
\hline Average+ & 0.001 & 0.001 & 0.003 & 0.005 & 0.005 & 0.006 & 0.007 & 0.008 \\
\hline$\overline{S D}$ & 0.001 & 0.003 & 0.005 & 0.009 & 0.009 & 0.011 & 0.012 & 0.014 \\
\hline
\end{tabular}


Fig. 3. Deviations visualized in each step with their corresponding resolution.

Resolution in " $\mathrm{x}$ " axis ( $\mathrm{mm} \mathrm{x} 0.1)$

Deviation in "y" axis (mm)

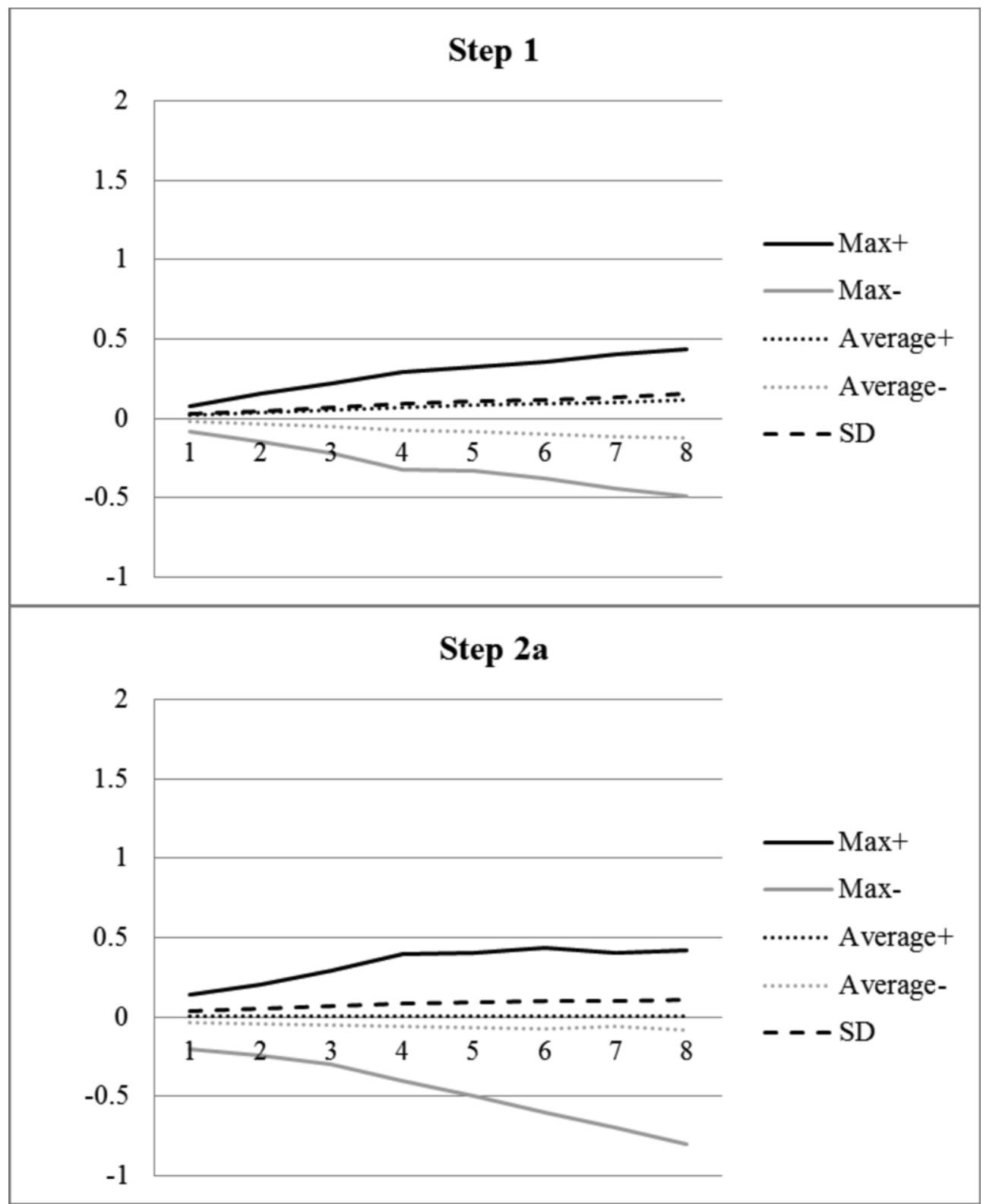



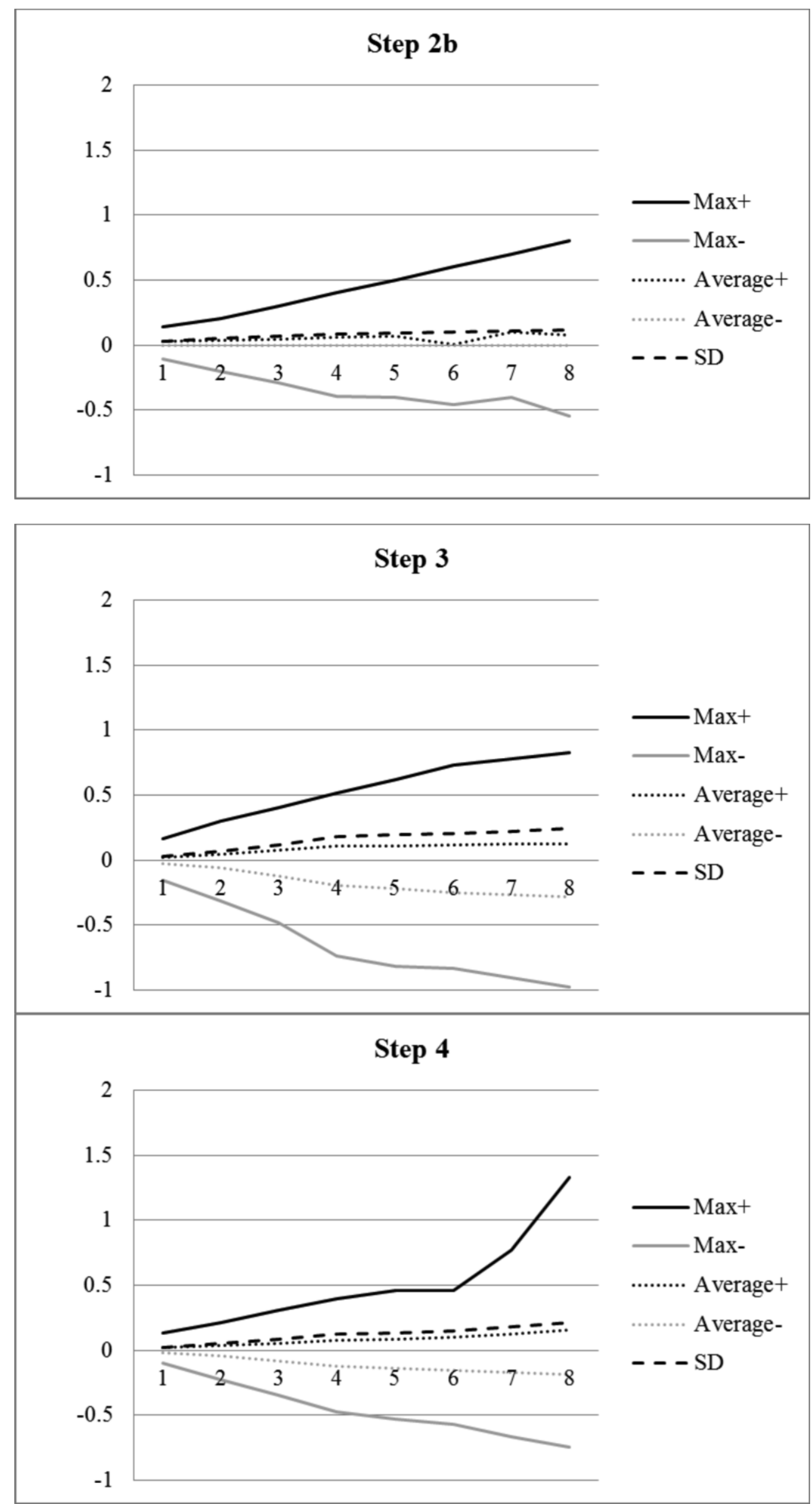


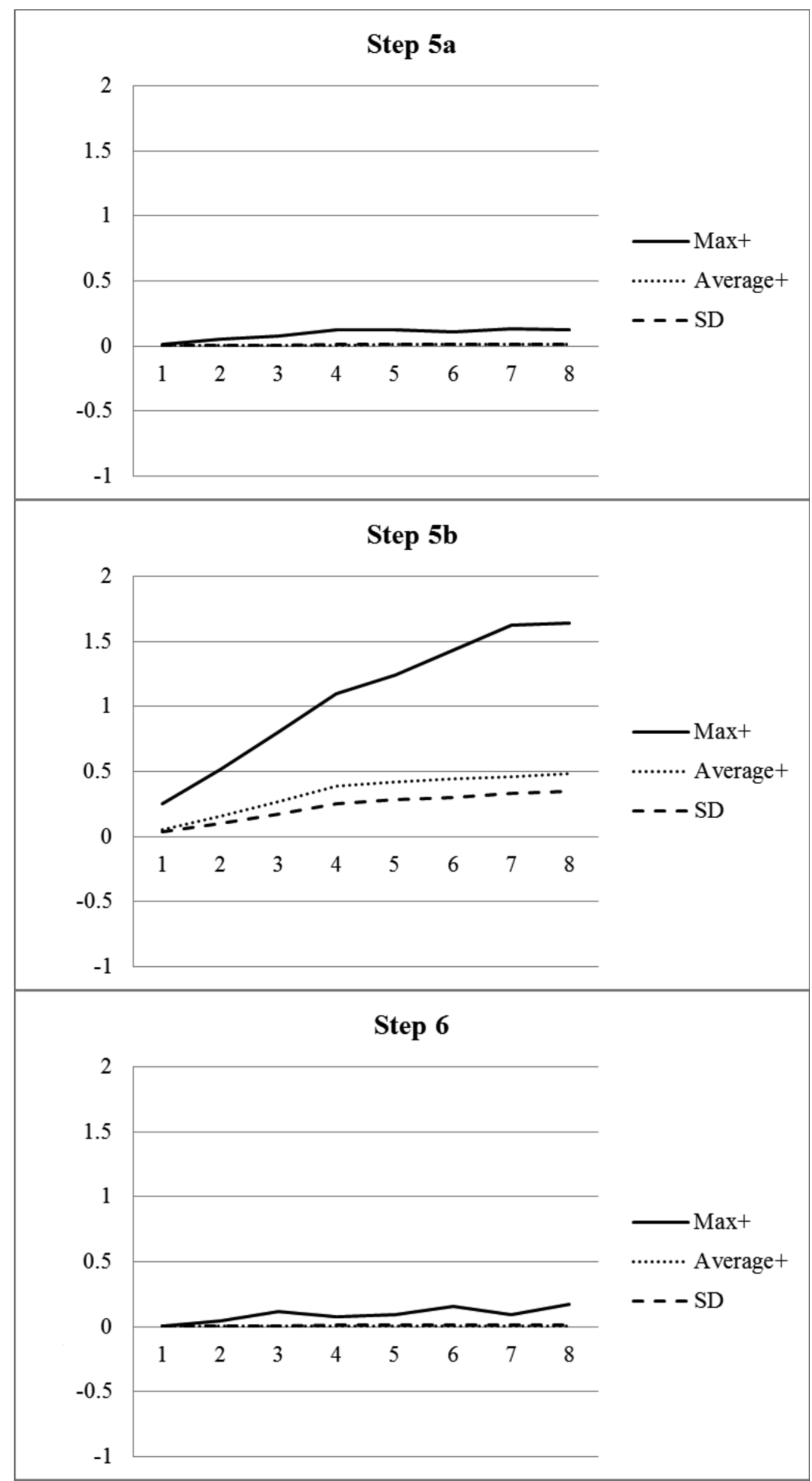


Fig. 4. Distance maps showing the different surface topology modifications. Uniform deviation pattern on the occlusial surface on the left side (Step 2a), and overall flattening the surface with filling the fissures and cutting the cusps on the right side (Step 3).
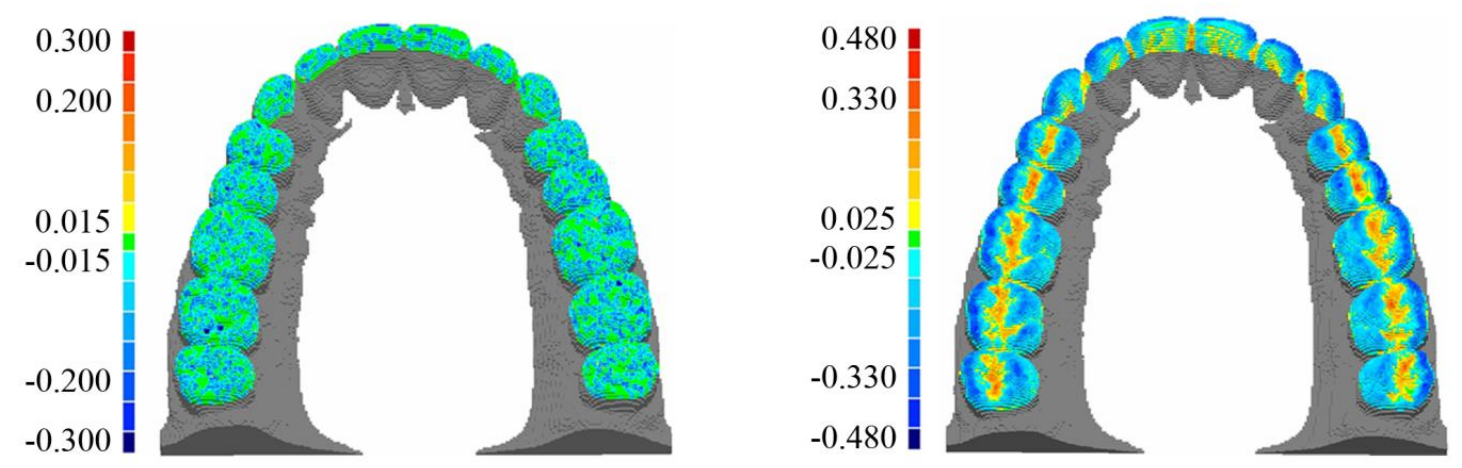


\section{INTERNATIONAL JOURNAL OF ORAL \& MAXILLOFACIAI Strderelen CONFIRMATION OF AUTHORSHIP FORM

Title of Submission: 3D modelling of the occlusal surface. What makes it accurate to be used for surgical planning?

Contributing Authors :-

Author: (surname and initials)

1. Endre Varga..

2. Beat Hammer.

3. Benjamin M Hardy.

4. Lukas Kamer.

5 .

6.

7.

8.

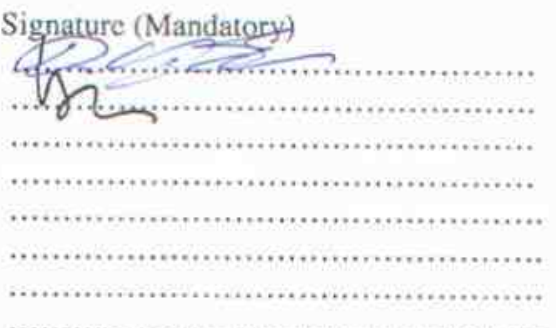

"I warrant that all the authors listed above have made a significant contribution to this manuscript and have agreed to its submission to the IJOMS".

Signed (corresponding author)

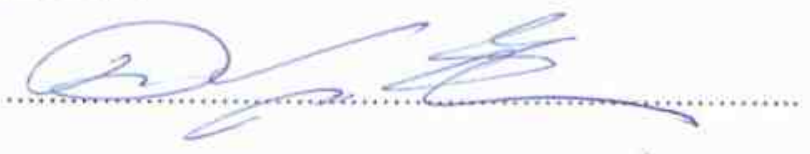

Name and Title of Corresponding Author: Endre Varga Dr. Med.

Dent.......

This form can be downloaded from the Guide to Authors (http://ees.elsevier.comlijoms) and must be signed by all authors. This signed form must be submitted prior to acceptance of your manuscript.

The form can either be scanned and uploaded into your submission, or alternatively, faxed to 01865843992 , or sent by post to the following address :-

IJOMS Editorial Office

c/o Jacqui Merrison

Elsevier Limited

The Boulevard

Langford Lane

Oxford

OX5 $1 \mathrm{~GB}$ 
Title of Submission: 3D modelling of the occlusal surface. What makes it accurate to be used for surgical planning?

Contributing Authors :-

Author: (surname and initials)

1. Endre Varga.

2. Beat Hammer.

3. Benjamin M Hardy

4. Lukas Kamer.

5.

6.

7.

8.

"I warrant that all the authors listed above have made a significant contribution to this manuscript and have agreed to its submission to the UOMS".

Signed (corresponding author)
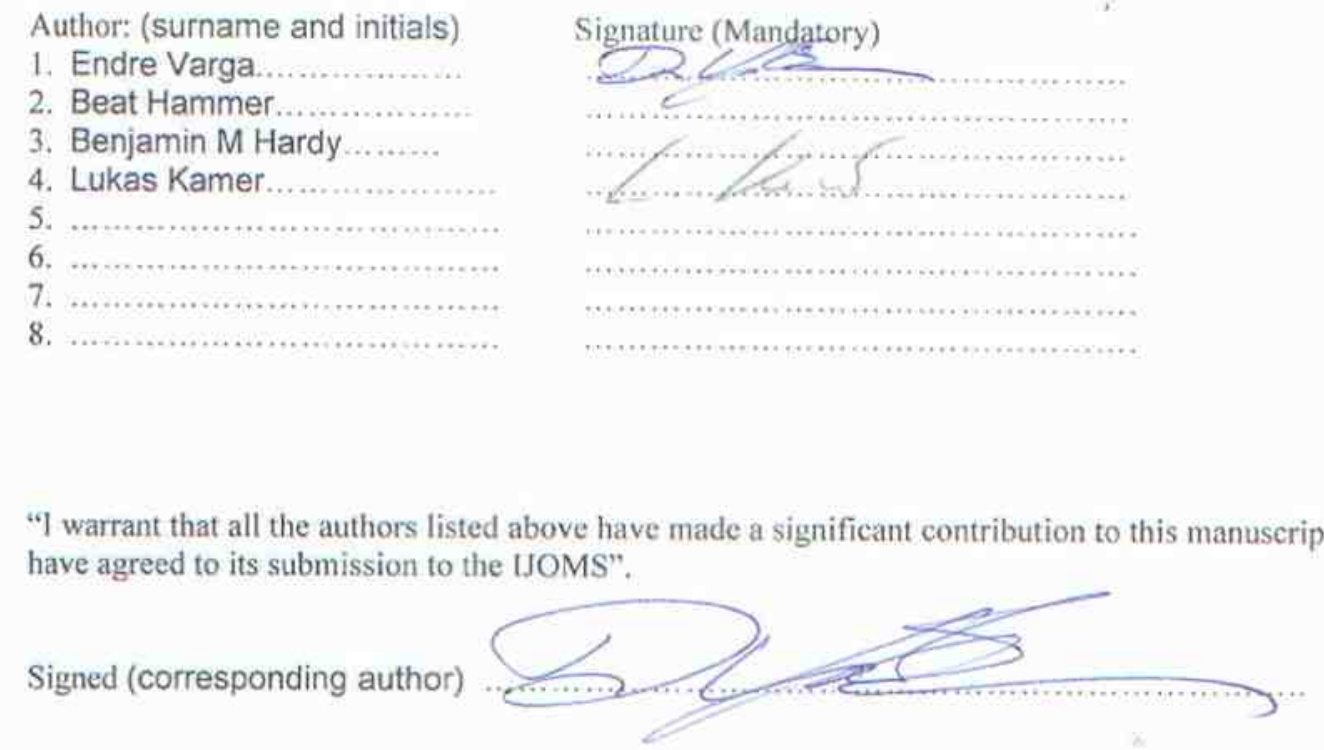

Name and Title of Corresponding Author: Endre Varga Dr. Med.

Dent.

This form can be downloaded from the Guide to Authors (http:/lees.elsevier.comlijoms) and must be signed by all authors. This signed form must be submitted prior to acceptance of your manuscript.

The form can either be scanned and uploaded into your submission, or alternatively, faxed to 01865843992 , or sent by post to the following address :-

IJOMS Editorial Office

clo Jacqui Merrison

Elsevier Limited

The Boulevard

Langford Lane

Oxford

OX5 1GB 


\section{Confirmation of Authorship form}

\section{INTERNATIONAL JOURNAL OF ORAL \& MAXILLOFACIAL SURGERY CONFIRMATION OF AUTHORSHIP FORM}

Title of Submission: 3D modelling of the occlusal surface. What makes it accurate to be used for surgical planning?

\section{Contributing Authors :-}

Author: (surname and initials)

1. Endre Varga.

Signature (Mandatory)

2. Beat Hammer.

3. Benjamin M Hardy......

4. Lukas Kamer.

5.

6.

7.

8.

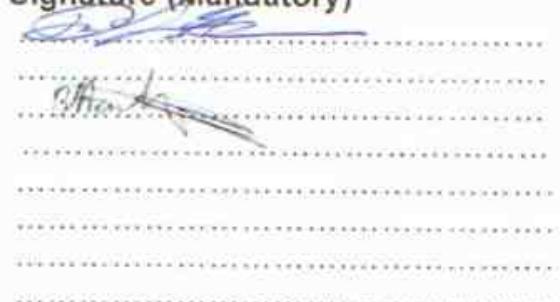

"I warrant that all the authors listed above have made a significant contribution to this manuscript and have agreed to its submission to the IJOMS".

Signed (corresponding author)

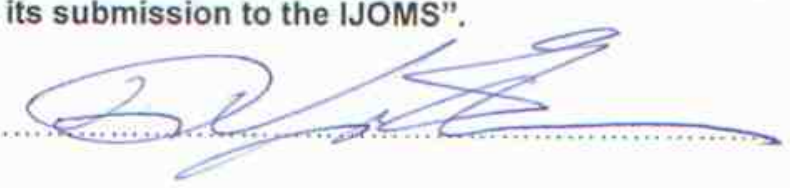

Name and Title of Corresponding Author: Endre Varga Dr. Med.

Dent.

This form can be downloaded from the Guide to Authors (http:/lees elsevier.comlijoms) and must be signed by all authors. This signed form must be submitted prior to acceptance of your manuscript.

The form can either be scanned and uploaded into your submission, or alternatively, faxed to 01865843992 , or sent by post to the following address :-

IJOMS Editorial Office

clo Jacqui Merrison

Elsevier Limited

The Boulevard

Langford Lane

Oxford

OX5 1GB 
Fig. 1. Image processing steps performed on 2D CT data.

The first line shows the impact of image resolution (A: $0.1 \mathrm{~mm}$ voxel size, B: $0.8 \mathrm{~mm}$ non isotropic).

Second line highlights the threshold segmentation (C: high, exclusive-, and D: low, inclusive settings, Resolution: 0.1mm).

Third line demonstrates the smoothing procedure (E: without smoothing, F: smoothed border line, Resolution: $0.3 \mathrm{~mm}$ )

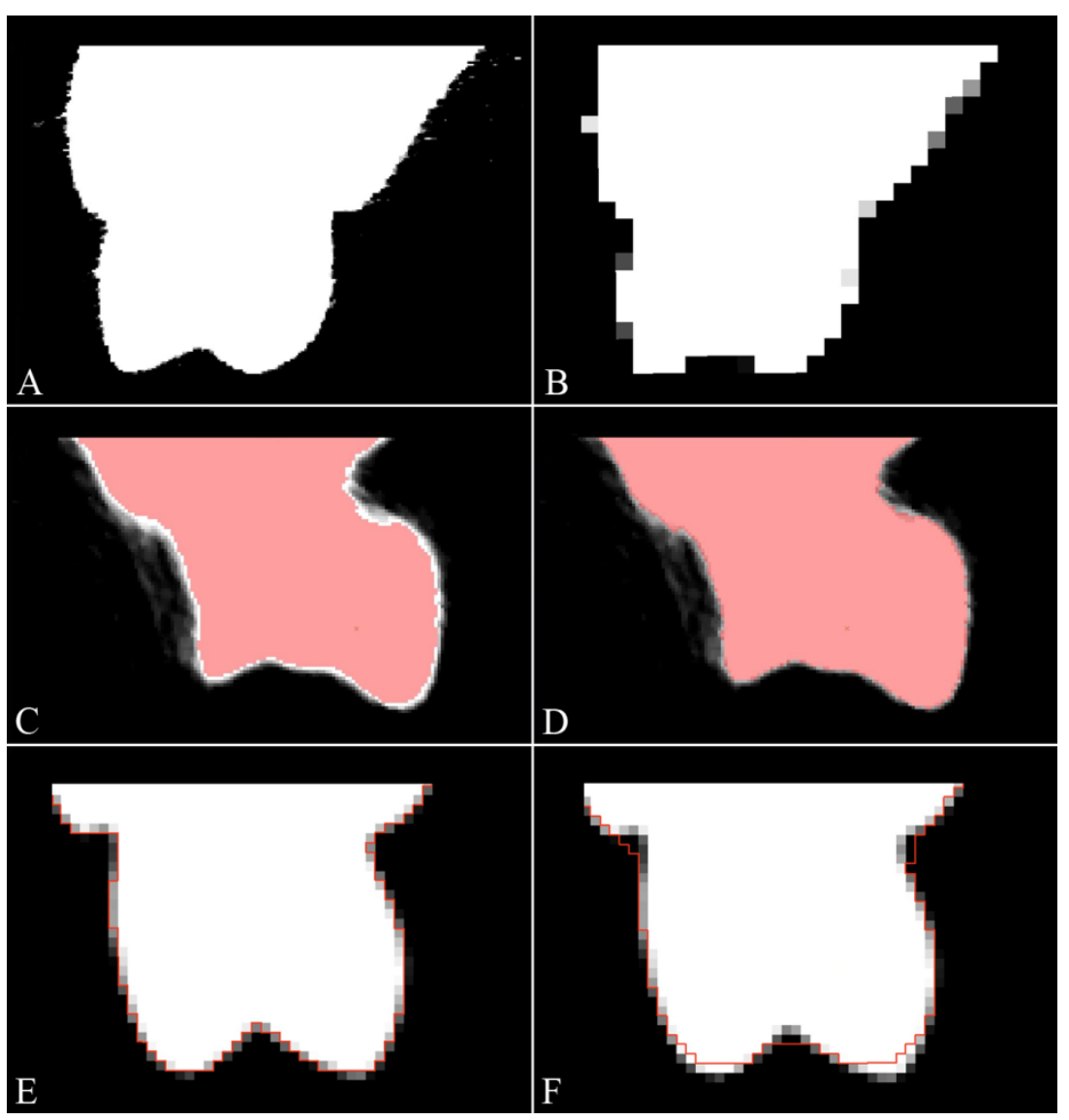


Fig. 2. The effects of image processing steps made on 3D data.

First line shows the effect of 3D model generation from 2D data with different algorithms (A:

LegoSurfaceGen, B: Marching Cubes Algorithm, Resolution: 0.4mm)

Effects of smoothing the 3D surface is visualized in the second line (C: moderate-, D: extensive smoothing, Resolution: 0.3mm)

Third line presents the result of reducing the number of the surface triangles (E: 41000 triangles, F: 20500 triangles, Resolution $0.4 \mathrm{~mm}$ )

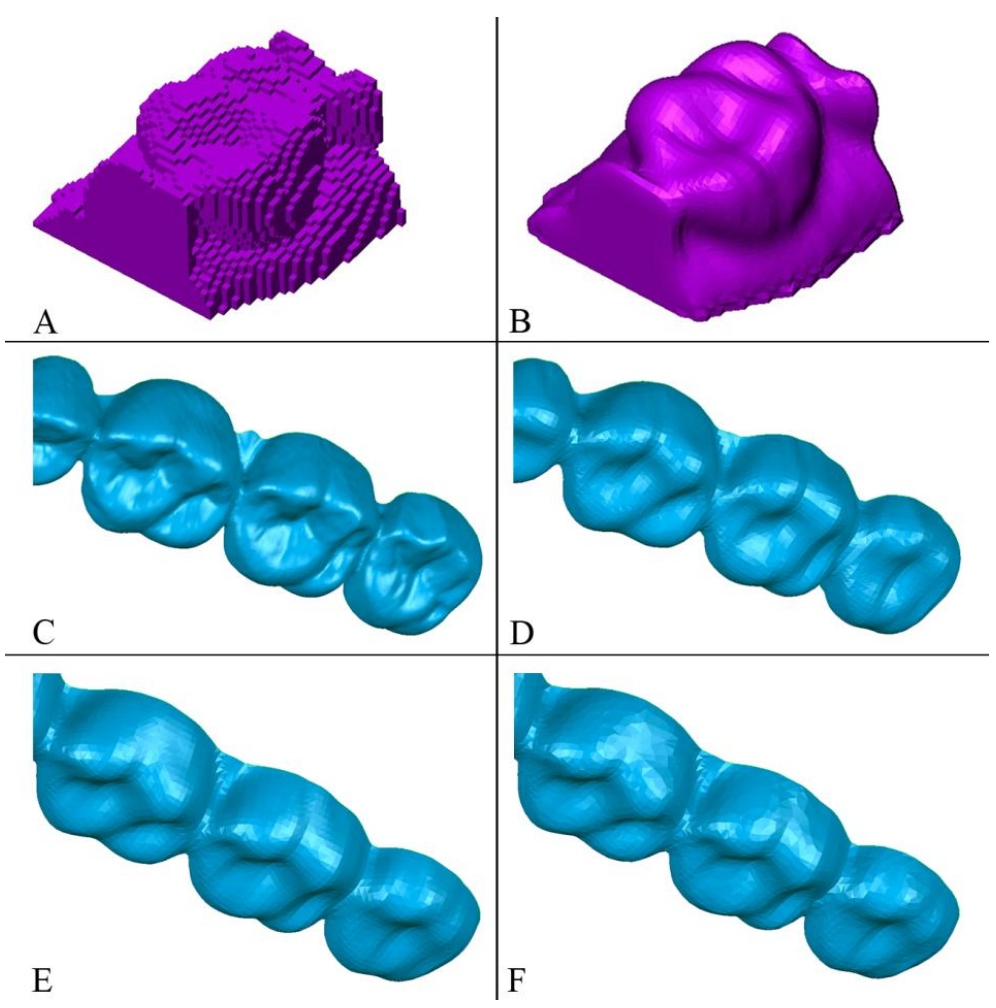


Fig. 3. Deviations visualized in each step with their corresponding resolution.

Resolution in " $\mathrm{x}$ " axis ( $\mathrm{mm} \mathrm{x}$ 0.1)

Deviation in "y" axis (mm)

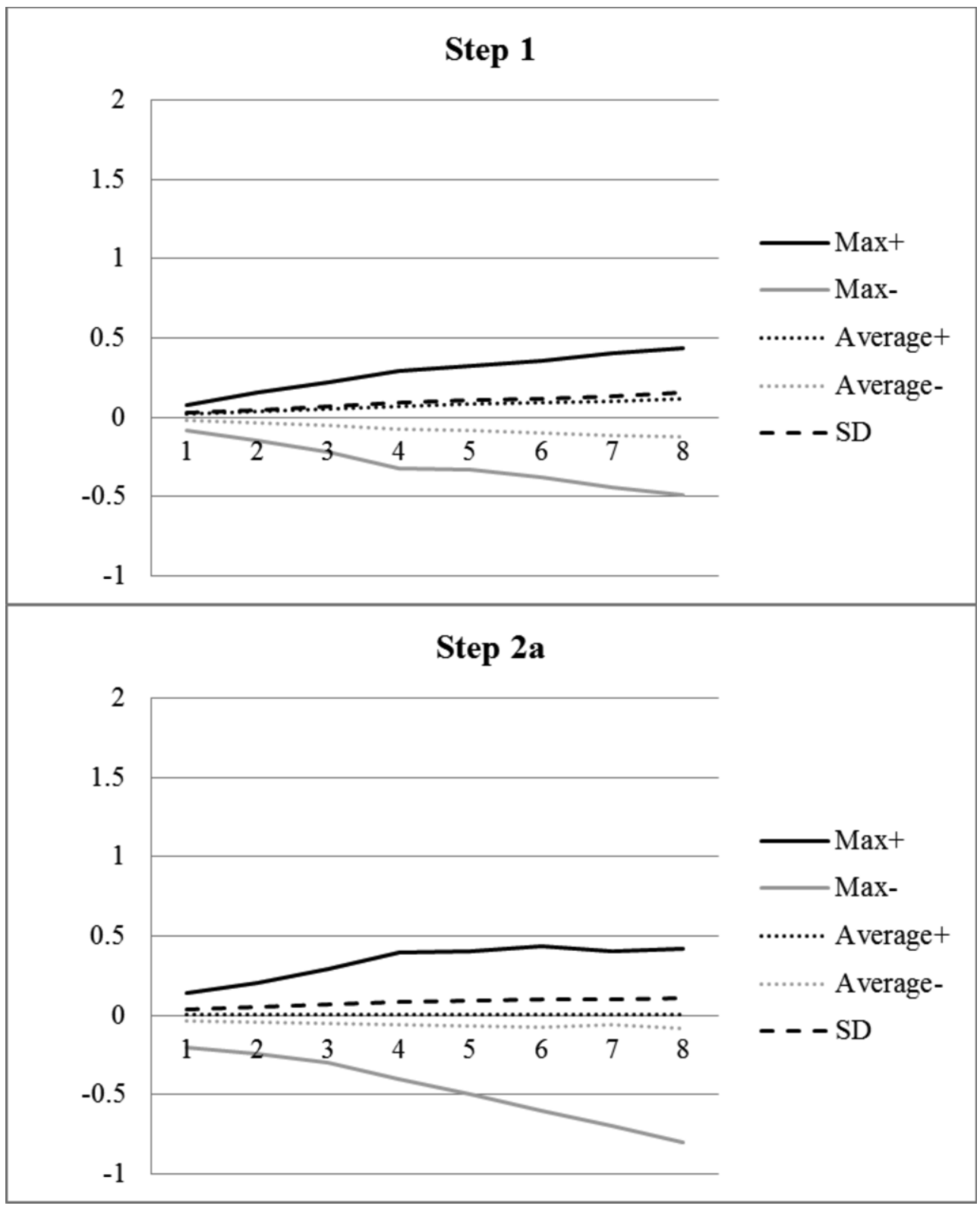



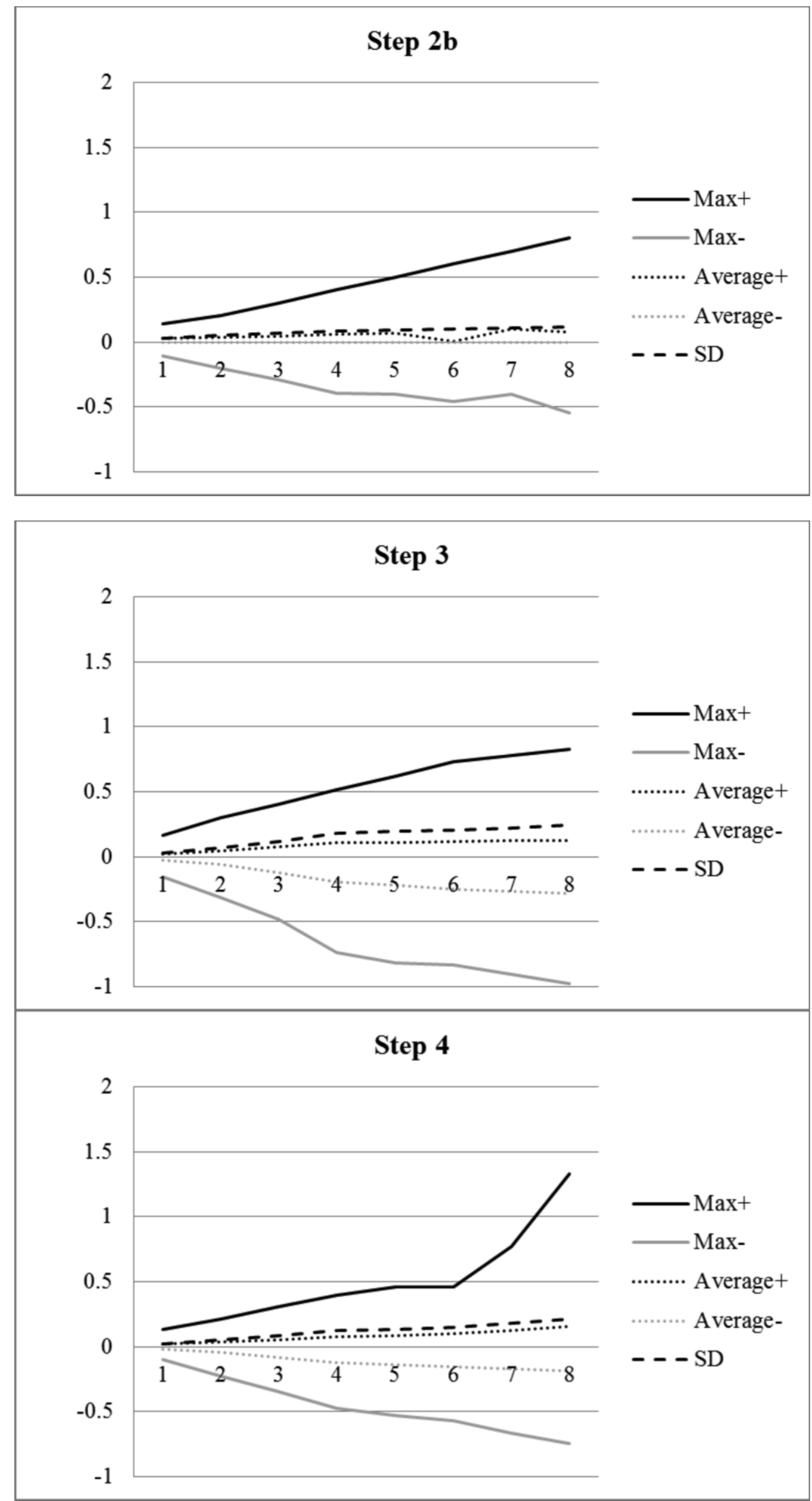


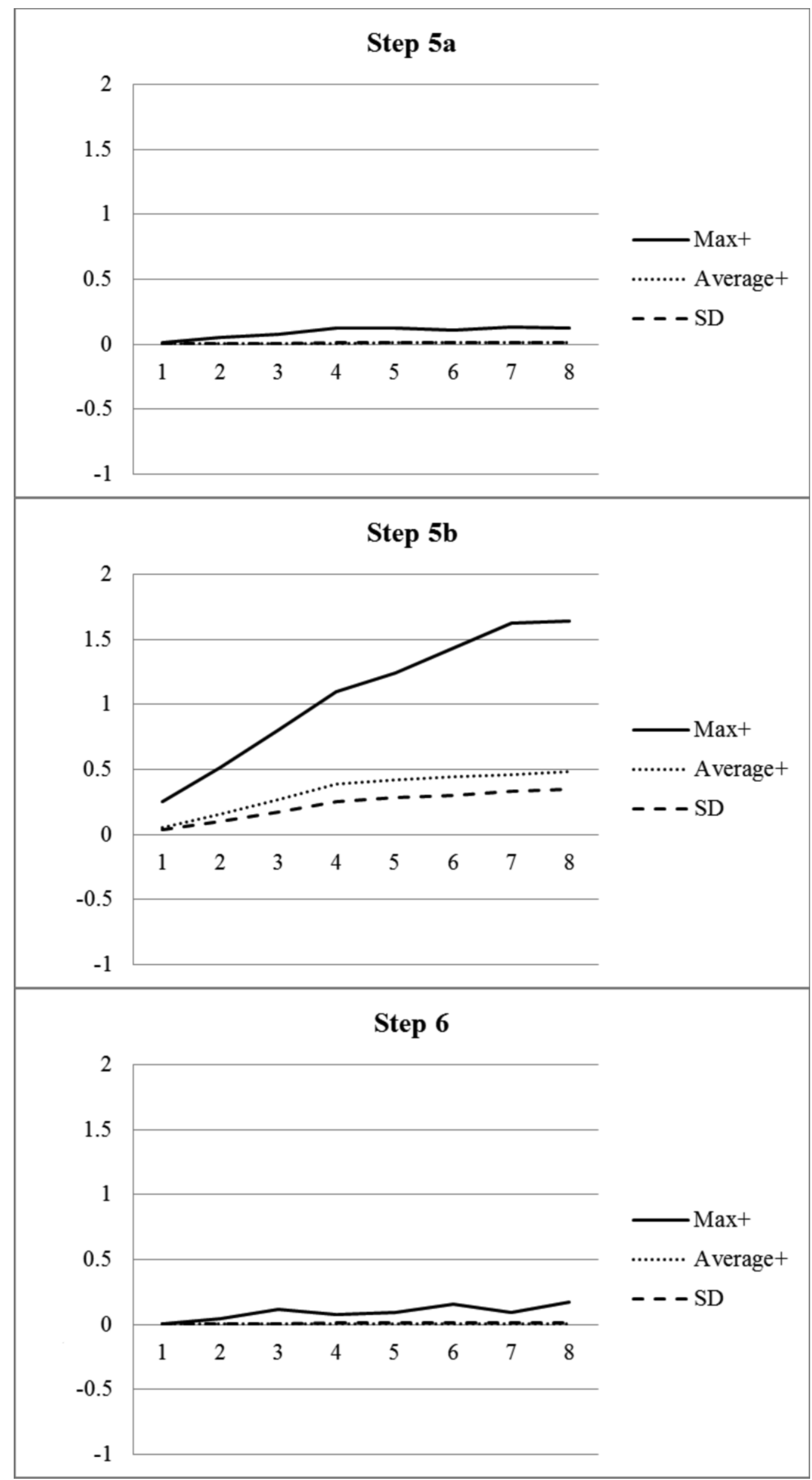


Fig. 4. Distance maps showing the different surface topology modifications. Uniform deviation pattern on the occlusial surface on the left side (Step 2a), and overall flattening the surface with filling the fissures and cutting the cusps on the right side (Step 3).
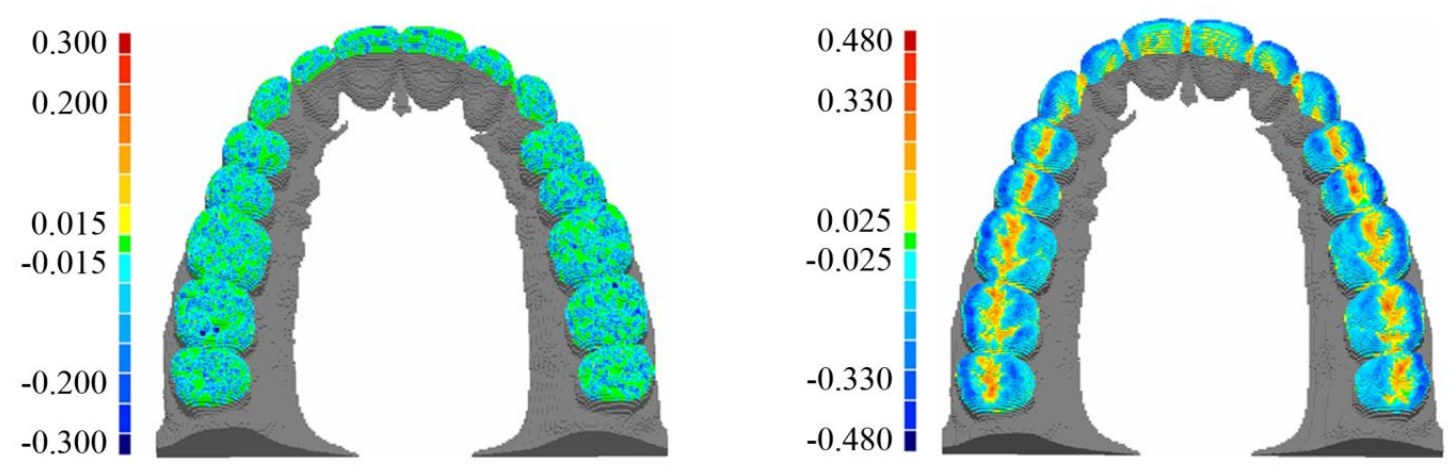
Table 1. Deviations in all steps and their corresponding resolution ( $\mathrm{mm})$.

\begin{tabular}{lcccccccc} 
Step 1 & 0.1 & 0.2 & 0.3 & 0.4 & $0.5(0.4)$ & $0.6(0.4)$ & $0.7(0.4)$ & $0.8(0.4)$ \\
\hline Max+ & 0.078 & 0.158 & 0.216 & 0.292 & 0.322 & 0.354 & 0.402 & 0.438 \\
\hline Max- & -0.08 & -0.145 & -0.22 & -0.324 & -0.335 & -0.382 & -0.444 & -0.492 \\
\hline Average+ & 0.021 & 0.035 & 0.053 & 0.071 & 0.082 & 0.09 & 0.103 & 0.117 \\
\hline Average- & -0.021 & -0.037 & -0.055 & -0.077 & -0.085 & -0.097 & -0.113 & -0.127 \\
\hline SD & 0.026 & 0.045 & 0.067 & 0.092 & 0.104 & 0.117 & 0.135 & 0.153 \\
\hline
\end{tabular}

\begin{tabular}{llllllllll}
\hline Step 2a & 0.1 & 0.2 & 0.3 & 0.4 & $0.5(0.4)$ & $0.6(0.4)$ & $0.7(0.4)$ & $0.8(0.4)$
\end{tabular}

\begin{tabular}{lcccccccc}
\hline Max + & 0.136 & 0.2 & 0.29 & 0.393 & 0.4 & 0.433 & 0.4 & 0.42 \\
\hline Max- & -0.2 & -0.245 & -0.3 & -0.4 & -0.5 & -0.6 & -0.7 & -0.8 \\
\hline Average+ & 0.001 & 0.004 & 0.004 & 0.003 & 0.004 & 0.004 & 0.006 & 0.005 \\
\hline Average- & -0.037 & -0.044 & -0.053 & -0.061 & -0.065 & -0.073 & -0.058 & -0.086 \\
\hline SD & 0.033 & 0.052 & 0.068 & 0.082 & 0.091 & 0.098 & 0.099 & 0.11 \\
\hline Step 2b & 0.1 & 0.2 & 0.3 & 0.4 & $0.5(0.4)$ & $0.6(0.4)$ & $0.7(0.4)$ & $0.8(0.4)$ \\
\hline Max+ & 0.136 & 0.2 & 0.3 & 0.4 & 0.5 & 0.6 & 0.7 & 0.8 \\
\hline Max- & -0.104 & -0.2 & -0.291 & -0.397 & -0.4 & -0.462 & -0.4 & -0.548 \\
\hline Average+ & 0.031 & 0.04 & 0.047 & 0.058 & 0.065 & 0.006 & 0.098 & 0.078 \\
\hline Average- & 0 & -0.003 & -0.003 & -0.003 & -0.004 & -0.004 & -0.005 & -0.006 \\
\hline SD & 0.031 & 0.05 & 0.066 & 0.086 & 0.093 & 0.099 & 0.104 & 0.112 \\
\hline Step 3 & 0.1 & 0.2 & 0.3 & 0.4 & $0.5(0.4)$ & $0.6(0.4)$ & $0.7(0.4)$ & $0.8(0.4)$ \\
\hline Max+ & 0.166 & 0.297 & 0.404 & 0.518 & 0.617 & 0.73 & 0.779 & 0.828 \\
\hline Max- & -0.152 & -0.318 & -0.479 & -0.741 & -0.818 & -0.833 & -0.904 & -0.978 \\
\hline Average+ & 0.018 & 0.042 & 0.074 & 0.107 & 0.11 & 0.117 & 0.12 & 0.122 \\
\hline Average- & -0.024 & -0.063 & -0.121 & -0.197 & -0.223 & -0.248 & -0.27 & -0.284 \\
\hline SD & 0.026 & 0.066 & 0.117 & 0.176 & 0.192 & 0.206 & 0.223 & 0.24 \\
\hline Step 4 & 0.1 & 0.2 & 0.3 & 0.4 & $0.5(0.4)$ & $0.6(0.4)$ & $0.7(0.4)$ & $0.8(0.4)$ \\
\hline Max+ & 0.129 & 0.214 & 0.31 & 0.398 & 0.461 & 0.456 & 0.771 & 1.329 \\
\hline Max- & -0.1 & -0.227 & -0.347 & -0.472 & -0.534 & -0.573 & -0.666 & -0.743 \\
\hline Average+ & 0.017 & 0.034 & 0.055 & 0.077 & 0.084 & 0.101 & 0.125 & 0.155 \\
\hline Average- & -0.02 & -0.046 & -0.08 & -0.124 & -0.139 & -0.153 & -0.171 & -0.187 \\
\hline SD & 0.022 & 0.049 & 0.083 & 0.121 & 0.133 & 0.15 & 0.177 & 0.208 \\
\hline Ste 5a & 0 & 0.2 & 0.3 & 0.4 & $0.5(0.4)$ & $0.6(0.4)$ & $0.7(0.4)$ & $0.8(0.4)$
\end{tabular}

\begin{tabular}{llllllllll}
\hline Step 5a & 0.1 & 0.2 & 0.3 & 0.4 & $0.5(0.4)$ & $0.6(0.4)$ & $0.7(0.4)$ & $0.8(0.4)$
\end{tabular}

\begin{tabular}{lllllllll}
\hline Max+ & 0.015 & 0.052 & 0.076 & 0.12 & 0.12 & 0.11 & 0.129 & 0.122 \\
\hline Averat & 0.001 & 0.002 & 0.005 & 0.008 & 0.009 & 0.009 & 0.01 & 0.012
\end{tabular}

\begin{tabular}{lllllllll}
\hline Average+ & 0.001 & 0.002 & 0.005 & 0.008 & 0.009 & 0.009 & 0.01 & 0.012
\end{tabular}

\begin{tabular}{lllllllll}
\hline SD & 0.001 & 0.003 & 0.007 & 0.01 & 0.012 & 0.012 & 0.014 & 0.015
\end{tabular}

\begin{tabular}{lllllllll}
\hline Step 5b & 0.1 & 0.2 & 0.3 & 0.4 & $0.5(0.4)$ & $0.6(0.4)$ & $0.7(0.4)$ & $0.8(0.4)$
\end{tabular}

\begin{tabular}{lcccccccc}
\hline Max + & 0.249 & 0.515 & 0.804 & 1.095 & 1.244 & 1.43 & 1.626 & 1.642 \\
\hline Average+ & 0.051 & 0.153 & 0.271 & 0.39 & 0.419 & 0.442 & 0.46 & 0.486 \\
\hline SD & 0.0376 & 0.098 & 0.173 & 0.254 & 0.28 & 0.302 & 0.328 & 0.346 \\
\hline Step 6 & 0.1 & 0.2 & 0.3 & 0.4 & $0.5(0.4)$ & $0.6(0.4)$ & $0.7(0.4)$ & $0.8(0.4)$ \\
\hline Max+ & 0.006 & 0.045 & 0.115 & 0.074 & 0.088 & 0.152 & 0.091 & 0.175 \\
\hline Average+ & 0.001 & 0.001 & 0.003 & 0.005 & 0.005 & 0.006 & 0.007 & 0.008 \\
\hline SD & 0.001 & 0.003 & 0.005 & 0.009 & 0.009 & 0.011 & 0.012 & 0.014
\end{tabular}




\title{
Correction of a severe facial asymmetry with computerized planning and with the use of a rapid prototyped surgical template: a case report/technique article
}

\author{
Laszlo Seres ${ }^{1 *}$ \\ * Corresponding author \\ Email: seres1@yahoo.com \\ Endre Varga Jr. ${ }^{1}$ \\ Email: endrevargadmd@yahoo.com \\ Andras Kocsis ${ }^{2}$ \\ Email: fogszab@fogszabalyzas.hu \\ Zoltan Rasko ${ }^{1}$ \\ Email: raskozoltan@gmail.com \\ Balazs Bago ${ }^{3}$ \\ Email: balazs.bago@smartds.eu \\ Endre Varga ${ }^{4}$ \\ Email: endrevargamd@yahoo.com \\ Jozsef Piffko ${ }^{1}$ \\ Email: piffko@maxillo.u-szeged.hu \\ ${ }^{1}$ Department of Oral and Maxillofacial Surgery, University of Szeged, Kalvaria \\ sgt. 57, 6725 Szeged, Hungary \\ ${ }^{2}$ Orthodontic Clinic, Marostoi u. 29/A, 6726 Szeged, Hungary \\ ${ }^{3}$ Smart Dental Solutions Ltd, Pulcz u. 46/B, 6724 Szeged, Hungary \\ ${ }^{4}$ Department of Traumatology, University of Szeged, Semmelweis u. 6, 6725 \\ Szeged, Hungary
}

\begin{abstract}
Management of significant facial asymmetry presents a challenge due to the geometric complexity of the bony and other facial structures. Manual model surgery is an essential part of treatment planning but it can be complicated, time-consuming and may contain potential errors. Computer-aided surgery has revolutionized the correction of maxillofacial deformities. The aim of this study was to report a case of facial asymmetry when computerised simulation surgery was performed instead of manual model surgery and a virtually planned wafer splint was fabricated. A 26-year-old male was presented with a severe right-sided hemimandibular elongation. Following presurgical orthodontics high-resolution computer tomography scan was performed. The stack images were reformatted into a three-
\end{abstract}


dimensional structure. Virtual Le Fort-I osteotomy was performed and the symmetry of the maxilla was corrected with the help of a three-dimensional planning software. A virtual intermediate surgical wafer was designed and produced with three-dimensional rapid prototyping technology. The mandible was rotated into the correct position following virtual bilateral sagittal split osteotomy to visualize the movements of the osteotomised mandibular segments. The two-jaw procedure was performed according to the virtual plan. The facial symmetry was improved significantly and stable occlusion was achieved. This complex case shows the advantages of computer-aided surgical planning and three-dimensional rapid prototyping for the correction of facial asymmetries.

\section{Keywords}

Virtual model surgery, Facial asymmetry, Computer-aided surgery, Digital intermediate wafer, Three-dimensional rapid prototyping

\section{Background}

Correction of severe facial asymmetry is a challenging task due to the geometric complexity of the dentition, the bony structures and the soft tissues. Mandibular asymmetry is usually associated with a unilateral vertical maxillary excess and an occlusal cant, therefore, in most cases the deformity cannot be treated with single-jaw surgery [1].

Traditional cephalometric analysis is of limited value in interpreting the cause of the asymmetry, because complex three-dimensional (3D) structures are projected onto twodimensional (2D) planes. Treatment planning of an asymmetric case requires threedimensional consideration in the sagittal, coronal and horizontal planes. Traditionally, manual model surgery is an essential part of the preoperative workup that involves many time-consuming laboratory based steps. When two-jaw surgery is performed, following the transposition of the maxilla on the stone dental model in the articulator an interocclusal splint is fabricated that serves as an intermediate guide for repositioning the maxilla relative to the intact mandible. The second, or final wafer relates the mobilized mandible to the fixated maxilla.

It is of critical importance that model surgery is based on accurate translation of the theoretical transposition data. Any discrepancy between the plan and the model surgery will lead to an inaccurate interocclusal splint. A poorly designed and/or fabricated wafer can lead to a disastrous outcome even when the most skillful surgical technique is used.

If a symmetric or slightly asymmetric face is operated on, when the jaws are moved mainly in the anteroposterior and vertical direction, traditional, 2D analysis and planning are usually satisfactory. But even in these cases, small errors in each step of model surgery can compound and lead to an inaccurate result [2-4].

Major asymmetry involving both the upper and lower jaws often requires complicated twojaw surgery. In these cases 3D planning is essential. The problem is twofold: first, how the most precise planning can be achieved and second, how the treatment plan can be transferred to the operating room. Accurate cephalometric analyses and 3D planning based on plain lateral and frontal cephalograms are hardly possible [5-7]. 
Improved imaging techniques and advances in software engineering have moved 3D computer models from the research and development area into routine clinical application [810]. Three-dimensional reconstruction images can be easily rotated and viewed from any angle. Accurate measurements can be performed on the maxillofacial complex and this helps not only to understand the etiology of facial asymmetry but to plan the osteotomies and movements of the segments.

Rapid prototyping is a remarkable, quickly evolving technology that has been revolutionizing the manufacturing process in several fields. With these technologies splints can be made that can guarantee the precise repositioning of the bony segments during surgery $[11,12]$.

The aim of this study is twofold, first, to investigate whether virtual 3D model surgery is suitable for treatment planning of an asymmetric two-jaw surgery, and second, to examine if rapid prototyping may eliminate the need for manual model surgery and the conventional fabrication of the interocclusal splint in the dental laboratory. A case of a severe facial asymmetry is reported when computer aided surgical planning was performed and the intermediate wafer was designed virtually and was manufactured by a three-dimensional printer.

\section{Case presentation/technique description}

A 26-year-old male complained of facial asymmetry and eating difficulties. Clinical evaluation revealed severe right-sided hemimandibular elongation with small compensatory transverse canting of the maxillary occlusal plane (Figure 1).

\section{Figure 1 (a) Initial facial view. (b) Initial facial smiling.}

Cross bite was observed on the left side. In the sagittal plane Class III malocclusion was noted on the right side while Class I molar and canine relationship was found on the left side. The mandibular front teeth, the left sided premolars and molars were lingually inclined. The maxillary midline was coincident with the facial midline. The mandibular dental midline and the mentum deviated to the left 11.8 and $15 \mathrm{~mm}$, respectively (Figures 2, 3 and 4). There was mild crowding in both arches. Technetium isotope failed to show increased uptake in the condylar regions.

\section{Figure 2 Initial panoramic radiograph.}

Figure 3 Pretreatment intraoral photograph.

Figure 4 Presurgery frontal cephalometric $x$-ray shows the compensatory transverse canting of the maxillary occlusal plane.

Preoperative orthodontic treatment lasted for 18 months and consisted of alignment and elimination of the transverse and sagittal dental compensation and arch coordination.

After presurgical orthodontic treatment was completed, computed tomography scan was obtained with an isotropic image resolution of $0.3 \mathrm{~mm}$ and standard image acquisition parameters $(60 \mathrm{kVp} / 40 \mathrm{keV}(900 \mu \mathrm{A})$. The patient was scanned in a supine position. The gantry had a zero inclination. The digital imaging and communication in medicine (DICOM) data were directly transferred to a personal computer. An in-house developed 3D planning 
software (JMed software, TraumArt Ltd, University of Szeged, Hungary) was used to reformat DICOM stack images into a 3D structure and to perform virtual preoperative surgical planning (Figure 5a).

\title{
Figure 5 (a) Preoperative CT scan. (b) Reference planes defined.
}

Three-dimensional facial analysis was performed following the construction of the midsagittal, the Frankfort horizontal and the mandibular planes (Figure 5b). Maxillary height, ramus length, body length, body height, frontal ramal inclination and lateral ramal inclination were measured on both sides. After evaluation of the factors that contributed the chin deviation virtual surgery was performed.

Selection of the bony structures was made by the software's semi-automatic segmentation tool and surface models were generated from each structure (Figure 6) [13,14]. Virtual conventional Le Fort I osteotomy was performed on the segmented models. The osteotomized segment was selected and was individually moved and rotated to reconstruct the symmetry of the maxilla (Figure 7a).

\section{Figure 6 (a) (b) Selection of the bony structures.}

\author{
Figure 7 (a) (b) Virtually repositioned maxilla (c) Virtually designed intermediate \\ wafer.
}

A model of a virtual intermediate surgical wafer was created with the maxilla in the planned position and the mandible in its original place (Figure 7b). The model of the wafer was printed with a 3D printer from a bio-compatible synthetic material that is suitable for shortterm mucosal-membrane contact (Figure 8). The splint was checked for occlusion on the patient's lower and upper dental arches and fitted well in both cases.

\section{Figure 8 (a) Model of intermediate wafer (b) 3D printed intermediate wafer.}

Following that the mandible was rotated into the correct position with virtual bilateral sagittal split osteotomy to visualise the movements of the osteotomized segments (Figure 9).

\section{Figure 9 (a) (b) Virtually repositioned mandible.}

In the surgical phase Le Fort I osteotomy was carried out as planned. The mobilized maxillary segment was rotated clockwise and was repositioned by application of the virtually planned intermediate wafer and mandibulomaxillary fixation. The virtually designated intermediate wafer fitted well during surgery (Figure 10). Miniplate fixation to the vertical facial buttresses was performed. Mandibulomaxillary fixation was then released and the bilateral sagittal split mandibular osteotomies were carried out. The distal segment of the mandible was rotated to the right and placed into the desired occlusion. Final splint was not used as the teeth were in good occlusion. Osteosynthesis was performed with titanium miniplates and screws (Figures 11 and 12). Postoperative intermaxillary fixation was maintained with tight elastics for 2 weeks. Loose guidance elastics were worn for a further period of 10 weeks. Two months after the surgical procedure, orthodontic treatment was resumed. Final arch coordination and occlusal settling were accomplished during the next 6 months (Figure 13). One year after the first surgery, genioplasty was performed at the same time of the removal of the previously implanted miniplates and screws. Standard 
intraoperative measurements were used without templates, the chin was rotated to the left by $4 \mathrm{mms}$ (Figures 14 and 15).

Figure 10 In surgery, the intermediate wafer fits well into the maxillary and mandibular dentition.

Figure 11 Panoramic radiograph after two-jaw surgery.

Figure 12 Postoperative frontal cephalometric x-ray shows that the facial symmetry has improved significantly.

Figure 13 Final intraoral photograph.

Figure 14 Final panoramic radiograph.

Figure 15 (a) Final facial view (b) Final facial smiling.

The facial symmetry was improved significantly after the operations. The occlusion is stable and the patient is satisfied with his facial appearance. There is no sign of relapse after 18 months following the first surgical procedure (Figure 16).

Figure 16 (a) (b) Postoperative CT scan.

A postoperative CT scan was made to evaluate the difference between the virtual Le Fort I osteotomy and the surgical result. The preoperatively planned model of the segmented maxilla was superimposed on the postoperative CT scan. The distance map generated between the superimposed models shows only minimal deviations on the bony structures (Figure 17).

Figure 17 (a) (b) Superimposition of the virtual plan and the final CT scan.

\section{Discussion}

When two-jaw surgery is planned for an asymmetric case spatial positioning of the maxilla is considered more critical than the repositioning of the mandible. Intermediate wafers are used more frequently than the final ones [15]. In our case reported, the key point of the procedure was the accurate repositioning of the maxilla. The maxillary segment mobilized via Le Fort I osteotomy showed acceptable intrinsic symmetry, therefore further maxillary osteotomies were not performed. The mobilized unit was placed symmetrically with respect to the sagittal plane. To achieve this it was rotated clockwise until the maxillary occlusal plane was parallel to the interpupillary line. At the same time a further rotation was performed in the horizontal plane to move the posterior part of the maxilla to the right. Amongst others, the complex rotational movement can be one of the sources of inaccuracies in manual model surgery. While with traditional methods treatment planning and model surgery are two separate steps, with virtual surgery these two procedures can be performed at the same time, there is no information loss between the two. The most complicated movements can be made precisely and the most accurate measurements can be calculated simultaneously. The final product of virtual model surgery is a virtual splint that can be materialized by rapid prototyping. This technique relies on the accuracy of the virtual model and the production of the surgical splint to ensure a successful surgery [16]. The intermediate wafer was fabricated with the highest 
printing accuracy in our case and it proved to be the most reliable tool to transfer virtual surgery into the operating room.

The new position of the mandible was determined by the repositioned maxilla. Virtual surgery showed that the mandible would be brought forward by $8.6 \mathrm{mms}$ on the left side. Manual model surgery focuses on the dentition and the occlusion but changes in the bony structure cannot be displayed. Although final wafer was not used as the mandible was simply placed into maximal intercuspal occlusion, virtual surgery still helped us to understand and visualize the rotational movement of the mandible.

\section{Conclusions}

Latest computerized and rapid prototyping technologies let us fully imagine, design and control orthognathic procedures without information loss among the surgeons, orthodontists and dental technicians. Any number of alternative treatment strategies can be investigated simultaneously during the planning phase. Computerised simulation surgery can be extremely useful in severe asymmetric cases when precise treatment planning with traditional methods is hardly possible. With this method manual model surgery and other laboratory steps can be avoided. The surgical wafer splint can be planned virtually and fabricated by a 3D printer.

\section{Consent}

Written informed consent was obtained from the patient for publication of this Case report and any accompanying images. A copy of the written consent is available for review by the Editor-in-Chief of this journal.

\section{Competing interests}

The authors declare that they have no competing interests.

\section{Authors' contributions}

LS is responsible for the design and writing of the paper; he took part in surgical planning and performed surgery. EVJr and BB participated in writing and finalizing the paper, the software development and virtual surgical planning. AK performed orthodontics and was responsible for surgical planning. ZR took part in surgical planning and surgery. EV is the group leader of the software development team. JP is the group leader and helped in the revision of the manuscript. All authors read and approved the final manuscript.

\section{References}

1. Cheong YW, Lo LJ: Facial asymmetry: etiology, evaluation, and management. Chang Gung Med J 2011, 34:341-351.

2. Cevidanes LH, Tucker S, Styner M, Kim H, Chapuis J, Reyes M, Proffit W, Turvey T, Jaskolka M: Three-dimensional surgical simulation. Am J Orthod Dentofacial Orthop 2010, 138:361-371. 
3. Ellis E III: Accuracy of model surgery: evaluation of an old technique and introduction of a new one. J Oral Maxillofac Surg 1990, 48:1161-1167.

4. Choi JY, Song KG, Baek SH: Virtual model surgery and wafer fabrication for orthognathic surgery. Int J Oral Maxillofac Surg 2009, 38:1306-1310.

5. Edler R, Wertheim D, Greenhill D: Outcome measurement in the correction of mandibular asymmetry. Am J Orthod Dentofacial Orthop 2004, 125:435-443.

6. Hwang HS, Hwang $\mathrm{CH}$, Lee $\mathrm{KH}$, Kang BC: Maxillofacial 3-dimensional image analysis for the diagnosis of facial asymmetry. Am J Orthod Dentofacial Orthop 2006, 130:779785 .

7. Gateno J, Xia JJ, Teichgraeber JF: A new three-dimensional cephalometric analysis for orthognathic surgery. J Oral Maxillofac Surg 2011, 69:606-622.

8. Baek SH, Kang SJ, Bell WH, Chu S, Kim HK: Fabricating a surgical wafer splint by three-dimensional virtual model surgery. In Distraction Osteogenesis of the Facial Skeleton. Edited by Bell WH, Guerrero CA. Hamilton, Ontario: BC Decker; 2006:115-130.

9. Swennen GR, Mollemans W, Schutyser F: Three-dimensional treatment planning of orthognathic surgery in the era of virtual imaging. J Oral Maxillofac Surg 2009, 67:2080-2092.

10. Hsu SS, Gateno J, Bell RB, Hirsch DL, Markiewicz MR, Teichgraeber JF, Zhou X, Xia JJ: Accuracy of a computer-aided surgical simulation protocol for orthognathic surgery: a prospective multicenter study. J Oral Maxillofac Surg 2013, 71:128-142.

11. Metzger MC, Hohlweg-Majert B, Schwarz U, Teschner M, Hammer B, Schmelzeisen R: Manufacturing splints for orthognathic surgery using three-dimensional printer. Oral Surg Oral Med Oral Pathol Oral Radiol Endod 2008, 105:e1-e7.

12. Levine JP, Patel A, Saadeh PB, Hirsch DL: Computer-aided design and manufacturing in craniomaxillofacial surgery: the new state of the art. J Craniofac Surg 2012, 23:288293.

13. Lorensen WE, Cline HE: Marching cubes: A high resolution 3D surface construction algorithm. Comp Graph 1987, 21:163-169.

14. Erdőhelyi B, Varga E, Kuba A: Surgical planning tool with biomechanical simulation. Proceedings of the International Conference on Computer Assisted Radiology and Surgery (CARS). Int J Comput Assist Radiol Surg 2007, 2:S262-S263.

15. Parbatani R, Williams AC, Ireland AJ, Sandy J: The process of orthognathic care in an NHS region. Ann $R$ Coll Surg Engl 2010, 92:34-39.

16. Varga E Jr, Hammer B, Hardy BM, Kamer L: The accuracy of three-dimensional model generation. What makes it accurate to be used for surgical planning? Int J Oral Maxillofac Surg 2013, 42:1159-1166. 


\title{
CAD/CAM technológia alkalmazása az implantációs sebészetben és protetikában
}

\author{
Dr. Varga Endre, Dr. Czinkóczlky Béla, Dr. Korpásy Viktória
}

Az implantációs fogpótlások készítésének protokolljai igen sokat változtak az utóbbi évtizedben. Minden újitás annak a törekvésnek a jegyében születik, hogy az elkészüló fogpótlások tökéletesek legyenek. Szintén egyre fontosabb szempont, hogy ezekkel képesek legyünk helyreállítani a fogatlansággal küzdô páciensek teljes rágófunkcióját, esztétikáját, és lehetôség szerint tökéletes rehabilitációt érjünk el. Ma már minden adott ahhoz, hogy a legmagasabb esztétikai igényeket is kielégitsük, és csak nagyon ritkán kell olyan kompromisszumokat kötnünk, amely a páciens életminőségét hátrányosan befolyásolná.

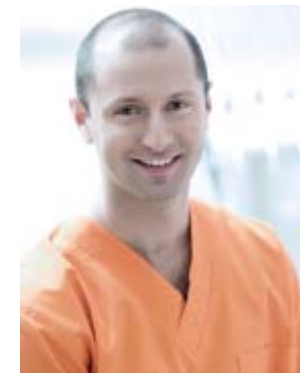

Dr. Varga Endre
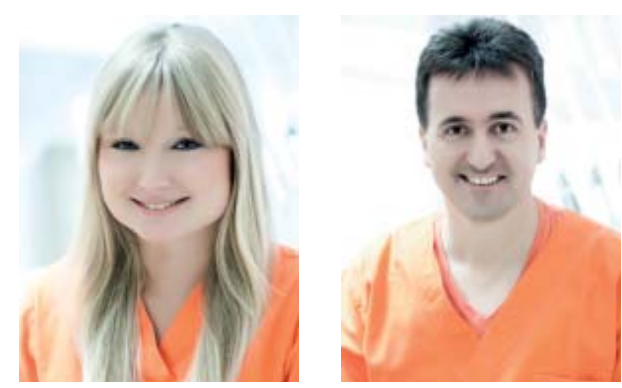

Dr. Korpásy Viktória Dr. Czinkóçky Béla
A CAD/CAM technológiák elterjedése egyrészt könynyebbé és pontosabbá, másrész jóval biztonságosabbá teszik a mútéti tervezéstés kivitelezést, arról nem is beszélve, hogy a páciens számára lényegesen kisebb megterhelést jelent egy ilyen módszerrel elvégzett műtét. A navigációs sebészet kivitelezése azon túl, hogy minimálinvazív volta miatt a lehető legkisebb sebbel jár, azt is biztositani tudja, hogy az implantátumok az előre megtervezett módon, és nem utolsósorban a készítendő fogpótláshoz illeszkedve, optimális pozícióban kerülhetnek beültetésre.

Az alábbi esetünkkel a digitális technológia lehetőségeit kívánjuk bemutatni a kiindulási állapottól az elkészített fogpótlás átadásáig.

Célunk, hogy megmutassuk azokat a lehetőségeket, amelyek segítségével a legpontosabban tudunk egy teljes rehabilitációt modellezni, tervezni és kivitelezni egy fogatlan állcsont esetében.

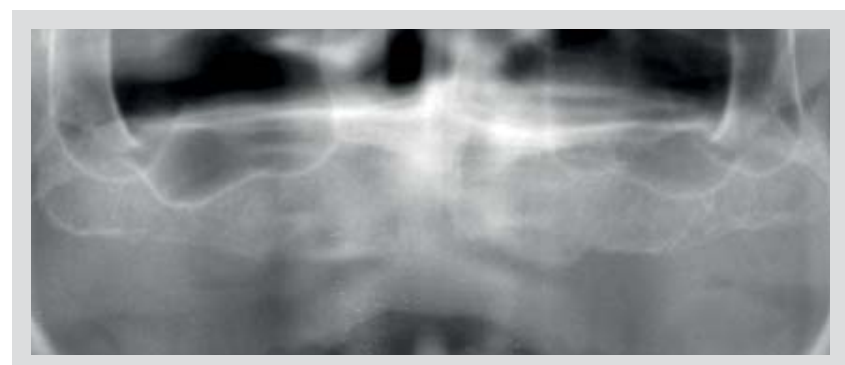

1. ábra: Fogatlan maxilla preoperatív panorámaröntgen-képe

\section{Esetbemutatás}

A páciens 36 éves nő, anamnézisében említésre érdemes adat nem szerepel, felső állcsontja teljesen fogatlan volt (1. ábra). Elmondása szerint felsô fogait folyamatosan veszítette el, kezelőorvosai és a saját „könnyelműsége” miatt. Parodontális státusza a korának megfelelő, így valószínűleg a folyamatosan kialakuló fogszuvasodások, majd az ennek következtében elvégzett foghúzások miatt vált fogatlanná. Teljes kivehető akrilát lemezes fogsort viselt, az elveszített fogak miatt a maxilla jelentős mértékben sorvadt, valamennyi régióban mind vertikális, mind horizontális csontpusztulás volt látható. Ezen tényezők miatt az implantáció nem volt lehetséges.

Amikor egy évvel ezelőtt a rendelőnkbe került, alapos szájvizsgálat, majd radiológiai vizsgálatok után csontpótlás és implantáció lehetőségét ajánlottuk fel neki, amit közösen átbeszéltünk, majd egy írásos kezelési terv rögzítése és aláírása után 2011 októberében kezdtük el a teljes rehabilitációt.

A processus alveolaris helyreállitását intraorálisan, a mentumból nyert csontblokkok segítségével végeztünk, illetve mindkét oldalon sinus elevációra is sor került (2. ábra). A csontgyógyulás után navigációs sebészeti módszerrel 6 darab Nobel Replace implantátumot ültettünk be, majd 3 hónapos gyógyulási időt követően kezdődött a fogpótlás elkészítése. Ez szintén CAD/CAM technológia segítségével valósult meg. 


\section{Anyag és módszer}

A csontpótlás után 4 hónapos gyógyulási idôt javasoltunk a páciensnek, majd ezt követően kezdtük el az implantáció megtervezését. A tervezett fogpótlást a kivehetô fogsorral modelleztük, az esztétikai elvárásokat azzal állítottuk be, majd annak elfogadása után azt vettük alapul a digitális tervezéskor (3. ábra). Az orvosi képalkotást a gyártó protokoll szerinti „double scan” technikával végeztük. Ez esetben készül egy felvétel a páciens állcsontjairól a szájában lévő CT sablonnal, illetve egy felvétel a CT sablonról külön a megfeleló regisztrációs pontokkal (4. ábra). A felvétel klinikai CBCTvel történt standard beállítások mellett. A kapott DICOM fájlokat implantációs műtéti tervező szoftverbe importáltuk (NobelClinician, Nobel Biocare Services AG).

Első lépésként kijelöltük az állcsontok, illetve a sablon felszíni határait (szegmentáció), majd regisztráltuk őket egymással. Ezeket a lépéseket a szoftver félautomatikusan

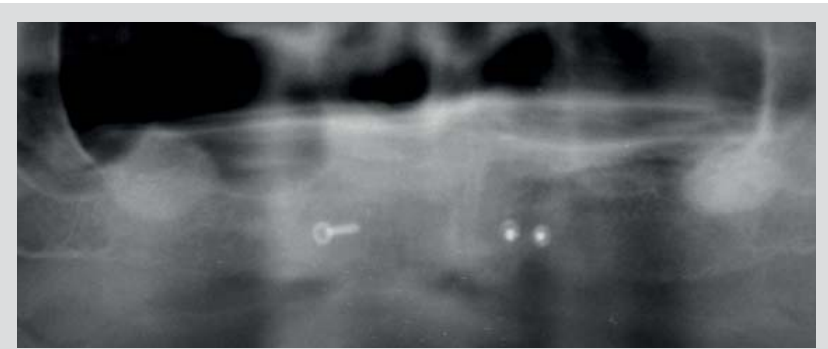

2. ábra: Sinus eleváció, vertikális és horizontális csontpótlás utáni állapot

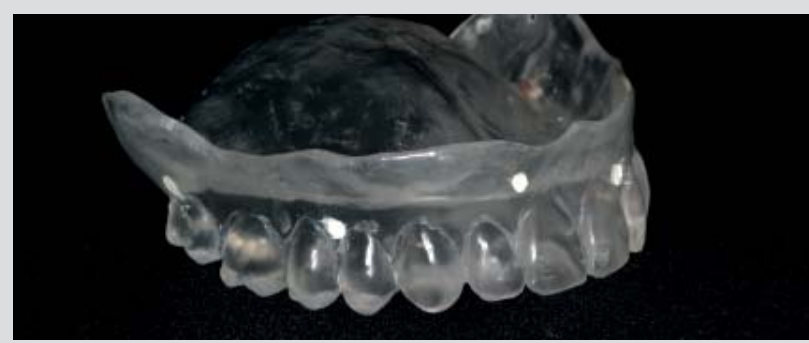

3. ábra: CT sablon a benne lévő regisztrációs markerekkel (guttapercha)

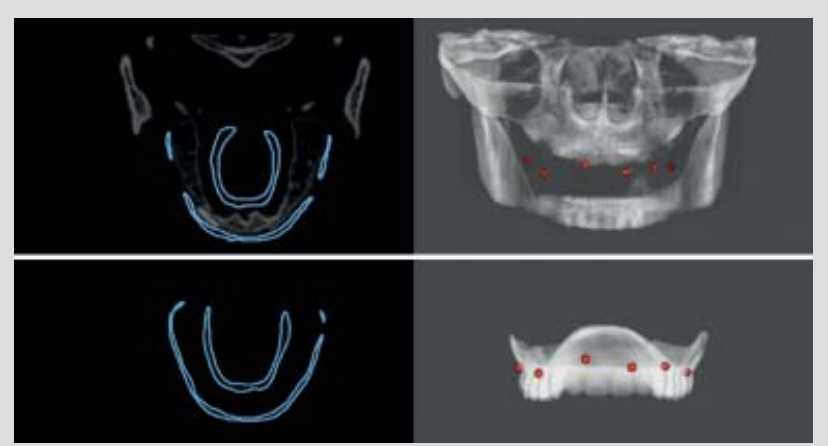

4. ábra: A „double scan” technika két külön felvétele. Az ábra bal oldalán a sablon és a koponya metszeti képe, a jobb oldalon ezek háromdimenziós megjelenítése látható a regisztrációs markerekkel végzi. A folyamat eredménye egy implantációs mútéti tervezésre alkalmas háromdimenziós modell (5. ábra).

A szoftver segítségével megadtuk a kívánt implantátumtípusok méreteit és állcsonthoz viszonyított pozícióit. Szintén megterveztük a sablon intraoperatív rögzítéséhez szükséges tüskék helyét és helyzetét, majd a véglegesített, kész tervet elküldtük a gyártóhoz (6/1-2. ábrák). A mútéti sablon fotopolimerizációs (stereolytography - SLA) technikával készült.

Két héttel a tervezés után altatásban került sor az implantátumok beültetésére (7. ábra). Mind a 6 implantátum primer stabilitása meghaladta a $35 \mathrm{Ncm}$-es értéket, így mindet transzgingivális gyógyulócsavarral (Healing Abutment) zártuk.

Zavartalan posztoperatív szak után a páciens tovább hordta a kivehető ideiglenes fogsorát, majd 3 hónap elteltével az integrálódott implantátumokra megkezdtük a végleges, rögzített fogpótlást készítését.

Csavarozott cirkónium vázra 12 tagú, kerámia leplezésú hidat terveztünk, melyet Procera technológiával készítettünk el (NobelProcera, Nobel Biocare Services AG)

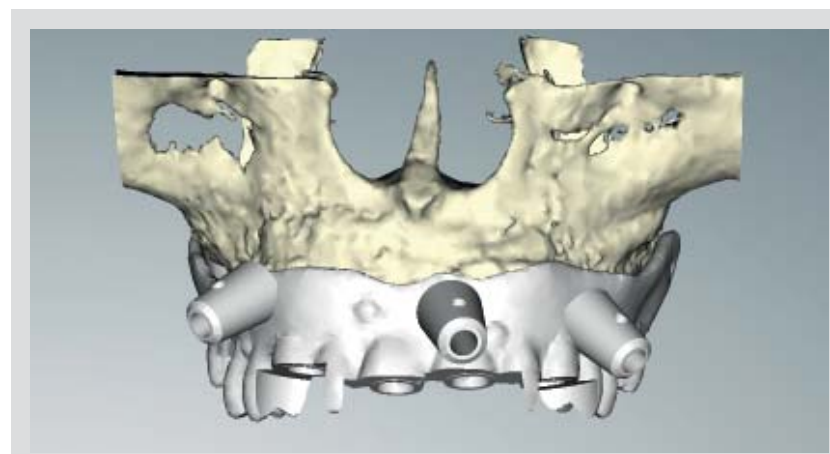

5. ábra: A maxilla és a fúrósablon felszín modellje a tervező szoftverben

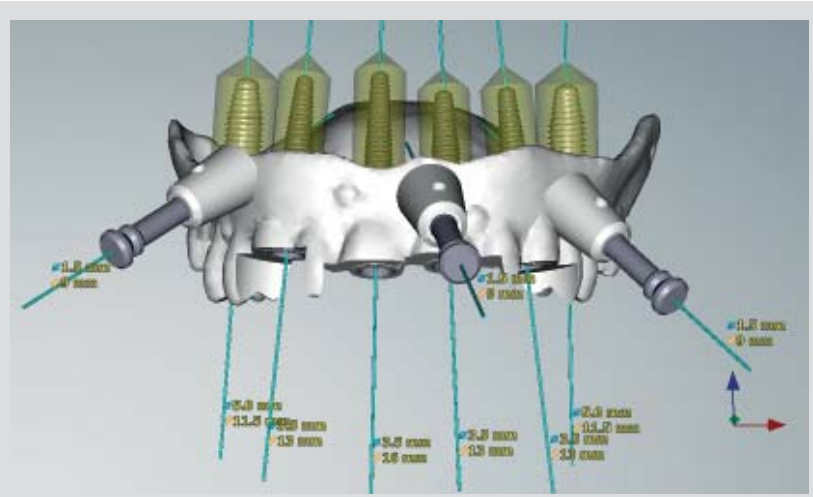

6/1. ábra: A betervezett implantátum-pozíciók a felszín modellen
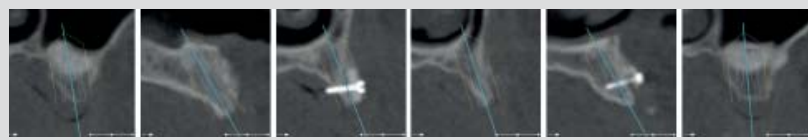

6/2. ábra: A tervezett implantátum-pozíciók keresztmetszeti képei 


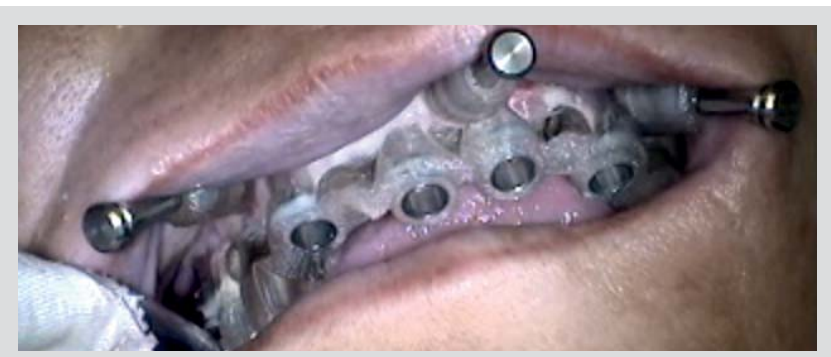

7. ábra: A szájban rögzített mútéti sablon
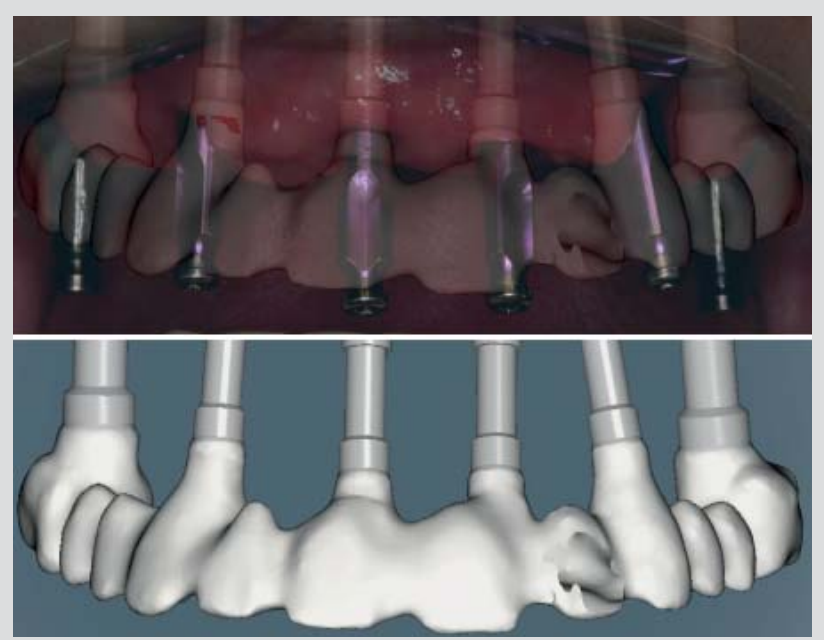

8. ábra: A digitális váz lenyomati elemekre szuperpozícionált és önálló képe

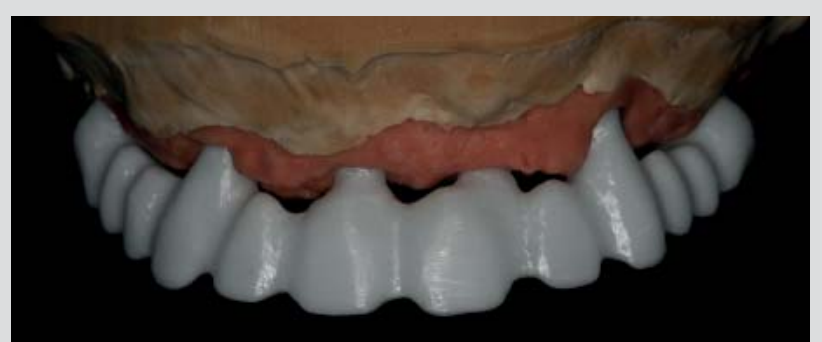

9. ábra: Elkészült cirkónium váz a gipszmodellen

(8. ábra). A digitális tervezés során az implantáció előtt elkészített ideiglenes fogpótlás adatait vettük figyelembe, melynek paramétereit igyekeztünk átültetni a végleges fogműre is. A virtuális hídváz adatait online elküldtük Stockholmba, a cég központjába, majd az elkészült cirkónium váz három munkanappal késóbb érkezett vissza a laborunkba (9. ábra). A porcelánleplezést individuálisan készítettük, és néhány intraorális próbafázis után véglegesítettük (10. ábra).

\section{Eredimény}

Miután a processus alveolaris adottságai még a csontpótlás ellenére sem érték el tökéletesen a páciens korának megfelelő, egészséges mértéket, így a tökéletes esztétikai hatás eléréséhez azt a megoldást választottuk, hogy a hidat rózsaszín kerámia múínnyel készítettük el.

Az elkészült hídpótlást az elôírt átmenő csavarokkal $35 \mathrm{Ncm}$-es nyomatékkal rögzítettük, majd a csavarbemeneti üregeket kiblokkoltuk, és folyékony kompozittal fel-

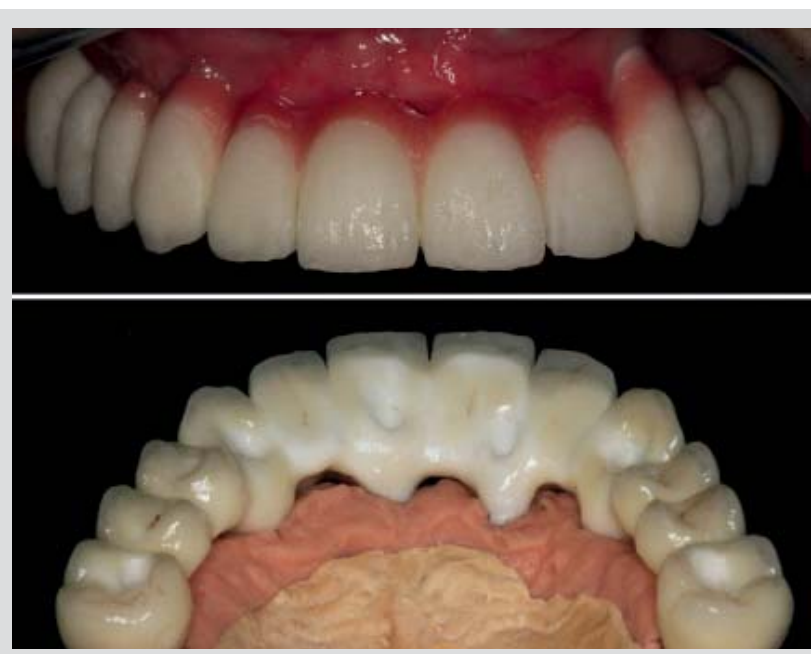

10. ábra: Kerámia leplezés matt próbája szájban és a kész pótlás gipszmodellen

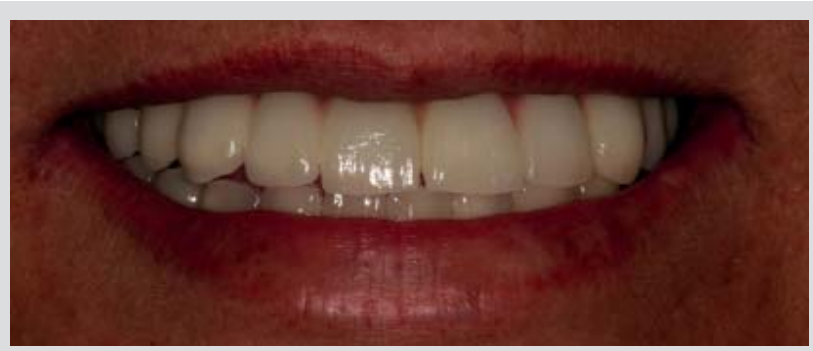

11. ábra: A végeredmény

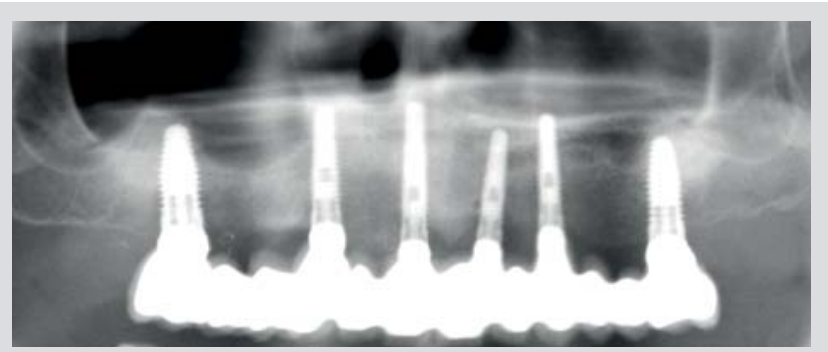

12. ábra: Három hónapos kontroll PCT felvétel

töltöttük (11. ábra). Felhívtuk a páciens figyelmét az átadott fogpótlás tisztán tartásának fontosságára, és alaposan megtanítottuk a híd ápolásának részleteire, módszereire, valamint kitértünk a rendszeres kontroll fontosságára is.

\section{Konkliúzió}

A CAD/CAM technológiák alkalmazása ma már nem korlátozódik a sebészi munkafázisok megtervezésére. Segítségével ugyancsak nagy pontossággal tudunk előre jósolható eredményt elérni a fogpótlások készítésekor is. Bemutatott esetünk kapcsán elmondható, hogy a virtuális tervezés minden lehetséges előnyét kihasználtuk, de a napi gyakorlatban lehetőség van egy-egy eset kapcsán csupán néhány elemének alkalmazására is. Segítségével megelőzhetô a nem kívánt sikertelenségek előfordulása, és biztosítható a legpontosabb sebészi kivitelezés, valamint a legmagasabb színvonalú esztétikai és protetikai irányelvek maradéktalan betartása. 


\section{ELJÁRÁS ÉS RENDSZER IMPLANTÁCIÓS SABLON TERVEZÉSÉRE ÉS ELŐÁLLÍTÁSÁRA}

A találmány tárgya eljárás implantációs sablon tervezésére és előállitására alkalmas rendszerben, ahol az eljárás tartalmazza, hogy szájképletről regisztrációs markerekkel ellátott kanállal lenyomatot készítünk; digitalizáljuk a lenyomatot; digitalizáljuk a beteget a lenyomattal a szájában; egy mútéti tervező számítógépes programmal összeregisztráljuk a két digitalizált képet, majd mútéti tervet készítünk; egy sablontervező számítógépes programmal a mútéti terv alapján elkészítjük az implantációs sablon digitális modelljét; az implantációs sablon digitális modellje alapján előállítjuk az implantációs sablon fizikai megfelelőjét. A találmány tárgya továbbá rendszer implantációs sablon tervezésére és elóállítására, amely tartalmaz lenyomatvételre alkalmas, regisztrációs markerekkel ellátott kanalat; egy műtéti tervező számítógépes programmal ellátott számítógépet a regisztráció elvégzésére, és a mútéti terv elkészítésére; egy sablontervező számítógépes programmal ellátott számítógépet az implantációs sablon tervezésére és előállítására; a mûtéti terv szerinti sebészeti tálcát; és a találmány szerinti eljárással megtervezett és előállított implantációs sablont.

A következőkben ismertetjük a technika állását.

A fogimplantációs eljárások során alkalmazott implantációs sablonokat a technika állása szerint a következő módon állítják elő. Először is az úgynevezett radiológiai sablont kell kialakítani több lépésben. Az ezzel kapcsolatos műveleteket a fogtechnikus végzi el.

Első lépésben az állcsontok egymáshoz viszonyított helyzetét és mozgását szimuláló eszközben, az artikulátorban elkészítik a páciens szájüregi képleteinek pozitív mását, azaz egy gipszmintát, felhasználva a páciens foglenyomatát. Majd ezen a gipszmintán az implantációs területen és annak környezetén valamilyen műanyagból kialakítják a sablon formáját. Ez egy hosszabb múveletsor manuális elvégzését jelenti, ahol először is a gipszmintán ki kell jelölni a sablon tervezett határait, majd a kijelölt határoknak megfelelően kell a sablont kialakítani.

A páciens szájképletei tartalmaznak úgynevezett alámenős részeket (például a fognyakak alatti területek vagy a fogak közötti hézagok), amelyek az implantációs sablon kemény anyaga miatt megakadályoznák a műtéti területre történő felhelyezhetőséget. A fogtechnikus ezeket a részeket felmelegített viasszal feltölti (blokkolja) a végleges radiológiai sablon alkalmazhatósága érdekében. Ez a mûvelet kifejezetten időigényes. 
Az így létrehozott sablont megfelelő műveletekkel a gipszminta, egy szilikon öntőforma és egy önkötő műanyag felhasználásával duplikálják. Az így kapott másolatot még további fizikai megmunkálásnak (faragás, csiszolás) vetik alá.

A tökéletes illeszkedés ellenőrzése érdekében a véglegesnek szánt radiológiai sablont vissza kell próbálni a páciens szájába. Jelentős pontatlanságok esetén akár az előbb ismertetett teljes eljárást meg kell ismételni.

A radiológiai sablon kialakítása során regisztrációs elemeket, úgynevezett radiodens markereket (vagy más kifejezéssel regisztrációs markereket) kell alkalmazni, amelyek a később elkészítendő CT-felvételeken mint referencia pontok jól azonosíthatók.

Az így előkészített radiológiai sablont a páciens szájába helyezik úgy, hogy az tökéletesen illeszkedjen a szájüregi képletekre (harapás regisztráció valamilyen viasz alkalmazásával), és elkészítik a szükséges CT-felvételt. Ezt követően még egy CT-felvétel készül külön a sablonról. Az ismertetett eljárást a gyakorlatban dual scan (vagy double scan) protokollnak nevezik.

A két felvétel elkészítését az indokolja, hogy a fogászati alkalmazásokban használt CT-felvételen (gyakran CBCT) csak a csontok láthatók jól, a lágy képletek (mint például az íny, a nyelv és az izmok) azonban elmosódott szürke foltokként jelennek meg. Így például egy fogatlan páciens esetén egyetlen CT-felvétel alapján nem lehetne eldönteni, hogy hol helyezkedik el az íny, amelyre a mútéti sablon rögzül. A dual scan protokoll és a CT-sablon biztosítja, hogy megállapítható legyen az ínynek a csonthoz és más szájképlethez viszonyított helyzete. A csontra és a lágy képletekre vonatkozó szükséges információ úgy nyerhető, hogy a két előzőleg elkészített CTfelvételt egymásra illesztik, összeregisztrálják az alkalmazott regisztrációs markerek segítségével.

Az összeregisztrált felvétel ismeretében az orvos meghatározza az implantátumok méretét, helyét és helyzetét, azaz az implantátumok tengelyének irányát, amelyek alapján a műtéti eszközök megvezetésére szolgáló fém perselyeket integrálják a fogtechnikus által az előző lépésekben készített vagy annak formája alapján egy 3D-s nyomtatóval elóállított sablonba.

Így tehát az előbbiekben leírt eljárásnak részét alkotja a fogtechnikus által elvégzett, többlépéses és manuális, következésképpen időigényes és költséges munkafolyamat, ami jelentősen 
megnehezíti, hogy az implantációs sablonokkal végzendő beavatkozások beilleszthetők legyenek a mindennapi rendelői rutinba.

Az EP1791491 számú európai szabadalmi irat többek között fogpótlás elóállítási eljárását ismerteti, ahol az eljárás magában foglalja azt a lépést, hogy két CT felvételt megfelelő számítógépes programban implementált eljárással illesztenek össze, ahol az egyik felvétel a páciens állcsontjáról, a másik CT felvétel a páciens szájképleteinek megfelelő gipszmintáról készült. A feltárt eljárás szerint az összeillesztett CT felvételek alapján tervezik meg az implantátum mélységét és irányát, valamint a navigációs eszközben a fúróvezető alakját. A hivatkozott dokumentum szerinti eljárás radiológiai sablon elkészítését igényli, ellentétben a jelen találmány szerinti eljárással.

Az US2010105010 számú amerikai szabadalmi irat olyan célú fogászati modell előállítását ismerteti, amely például fogimplantációs műtétek tervezése és végrehajtása során alkalmazható. A hivatkozott dokumentumban ismertetett eljárás magában foglalja, hogy a) digitális képet készítenek a páciens szájképleteirôl; b) a kapott digitális képet a páciens fogai alapján szegmentálják; c) a szegmentált képen belül azonosítják az implantációs helyet; d) az implantációs helyen meghatározzák a pilot furat dimenzióit; e) a tervek alapján elkészítik a tanulmányi mintát a pilot furattal; f) a tanulmányi mintában elhelyezik a fúróperselyeket; g) az így elôkészített tanulmányi mintáról ezután egy implantációs sablonként funkcionáló transzfer-sablont készítenek. A hivatkozott dokumentáció alkalmaz ugyan szoftveres tervezést, azonban az implantációs sablon előállításához egy fizikai minta elkészítése is szükséges.

A WO9426199 számú nemzetközi szabadalmi irat radiodens anyaggal legalább részben bevont fogászati kanalat és egy ezt felhasználó eljárást ismertet fogimplantáció elvégzésére. Az ismertetett eljárás során a kanalat a páciens szájába helyezik, majd keresztmetszeti röntgenfelvételeket készítenek az alsó állkapocsról és a kanálról; a felvételek alapján meghatározzák az implantátum optimális pozícióját; a kanalat egy automata rendszerhez kapcsolt tartóra helyezik, ahol röntgenfelvételeket készítenek arról; a kapott felvételeket egyesítik a korábbi felvételekkel és meghatározzák a furatok tengelyét, majd az automata rendszerrel furatok készítenek a kanálon. Az így kapott kanalat mint sablont használják az implantátumok alsó állcsontba történő elhelyezésére. 
Az US20040101803 számú amerikai szabadalmi irat egy igen összetett, lenyomatvételre alkalmas kanalat ismertet, amely magában foglal többek között egy két részre osztott merev keretet és a kerethez rögzített membránt, amelynek feszítettsége egy huzallal szabályozható. Használat előtt a keret két részének illeszkedési pontját valamilyen önkötő anyaggal be kell vonni, illetve a membrán mindkét oldalán lenyomatvételre alkalmas anyagot kell alkalmazni és így kell behelyezni a beteg szájába. Ezután a huzalt eltávolítják, hogy a keret két része egymástól függetlenül tudjon elmozdulni a harapás hatására. A hivatkozott dokumentum szerinti alkalmazása meglehetősen nehézkesnek tűnik.

A WO2008057955 számú nemzetközi szabadalmi irat egyebek mellett ismertet egy eljárást fogimplantációs sablon előallítására, amely magában foglalja a következő lépéseket: a) lenyomatot készítenek az implantációs területről; b) a lenyomat alapján egy fizikai modellt készítenek; c) egy előre gyártott, fog alakú sablonokból álló készletből kiválasztanak egy megfelelôt fogsablont; d) a kiválasztott fogsablont a modellre illesztik; e) a fogsablont tartalmazó modellről egy újabb lenyomatot készítenek; f) az így kapott újabb lenyomatba lyukat fúrnak a furattal ellátott, korábban használt fogmodell segítségével, így egy implantációs sablonhoz jutnak. A jelen találmányhoz viszonyítva a hivatkozott dokumentum szerinti eljárás hosszadalmas, manuális műveleteket igényel.

A WO9932045 számú nemzetközi szabadalmi irat szintén egy eljárást ismertet implantációs sablon előállítására, ahol a páciens tipikusan teljesen fogatlan. Az eljárás során 3D-s számítógépes grafikus modellt állítanak elő az állcsont és a szövetstruktúra leképezésével az íny felületéhez viszonyítva, ahol a leképezést röntgen vagy MRI technikával végzik. Előnyösen az ínyhez illeszkedő radiológiai sablont alkalmaznak. Az implantátumok furatának adatait a 3D-s modell alapján határozzák meg. Az implantációs sablontest előállítását a hivatkozott dokumentum nem tárja fel, csak annyit ismertet, hogy azt egy fizikai modellen alakítják ki, majd az így kapott sablontesten a furatokat a 3D-s modell alapján meghatározott adatok szerint CNC eszközzel készítik el.

A WO2010133326 számú nemzetközi szabadalmi irat részletesen ismerteti azt az általános eljárást, amely alapja a korábban már említett dual scan protokollnak, valamint a kraniofaciális beavatkozások virtuális megtervezésének. A dokumentum ismerteti, hogy az eljárás során két adathalmazt állítanak elő. Az egyik adathalmaz a felszíni struktúrákról, a másik adathalmaz a felszín alatti, nem látható struktúrákról szolgáltat vizuálisan megjeleníthető adatokat. A 
fogimplantáció szempontjából ez a lágyszövetek és a csontszövetek leképezésének felel meg. Az így kapott két adathalmazt azután egyesítik. A hivatkozott dokumentum említi ugyan, hogy a feltárt eljárás többek között alkalmas implantációs sablon megtervezésére is, ugyanakkor leírja, hogy a fogak, a lágyszövetek és a foghiányos helyek leképezésekor radiológiai sablont alkalmaznak.

Az US2013144422 számú amerikai szabadalmi irat szintén eljárást és rendszert ismertet fogimplantációs sablon előállítására. A bemutatott eljárás során egy virtuális modellt hoznak létre CT-vel nyert adatok és a tervezett implantátumok virtuális megfelelője alapján. A hivatkozott dokumentum említi, hogy a virtuális modell kialakítása olyan fizikai modellt is igényel, amelyet hagyományos fogászati laboratóriumi technikákkal állítanak elő. A szoftveres tervezést követően valamilyen gyors prototípusgyártással (például 3D-s nyomtatással vagy marással) előállítják a virtuális modell fizikai megfelelőjét. Az implantációs sablontestet az így legyártott fizikai modellen termoformázással állítják elő, ezt követően a fölösleges részeket fizikai műveletekkel eltávolítják, majd a sablontestet fémperselyekkel látják el.

Az US2010240000 számú amerikai szabadalmi irat az előző dokumentumban feltárt eljáráshoz hasnló eljárást ismertet. Az implantációs sablontestet (negatív sablontest) is egy előzőleg előállított, fizikai modellt felhasználva állítják elő termoplasztikus anyagból vákumformázással. A fizilai modell előállítása során, más mûveletek mellett, a páciens szájképletéről lenyomatot (negatív modell) vesznek, amelyről aztán egy pozítív modellt készítenek, és ezt a pozitív modell digitalizálják. 
Az ábrák rövid ismertetése

1. ábra:

A találmány szerinti eljárás teljes folyamata.

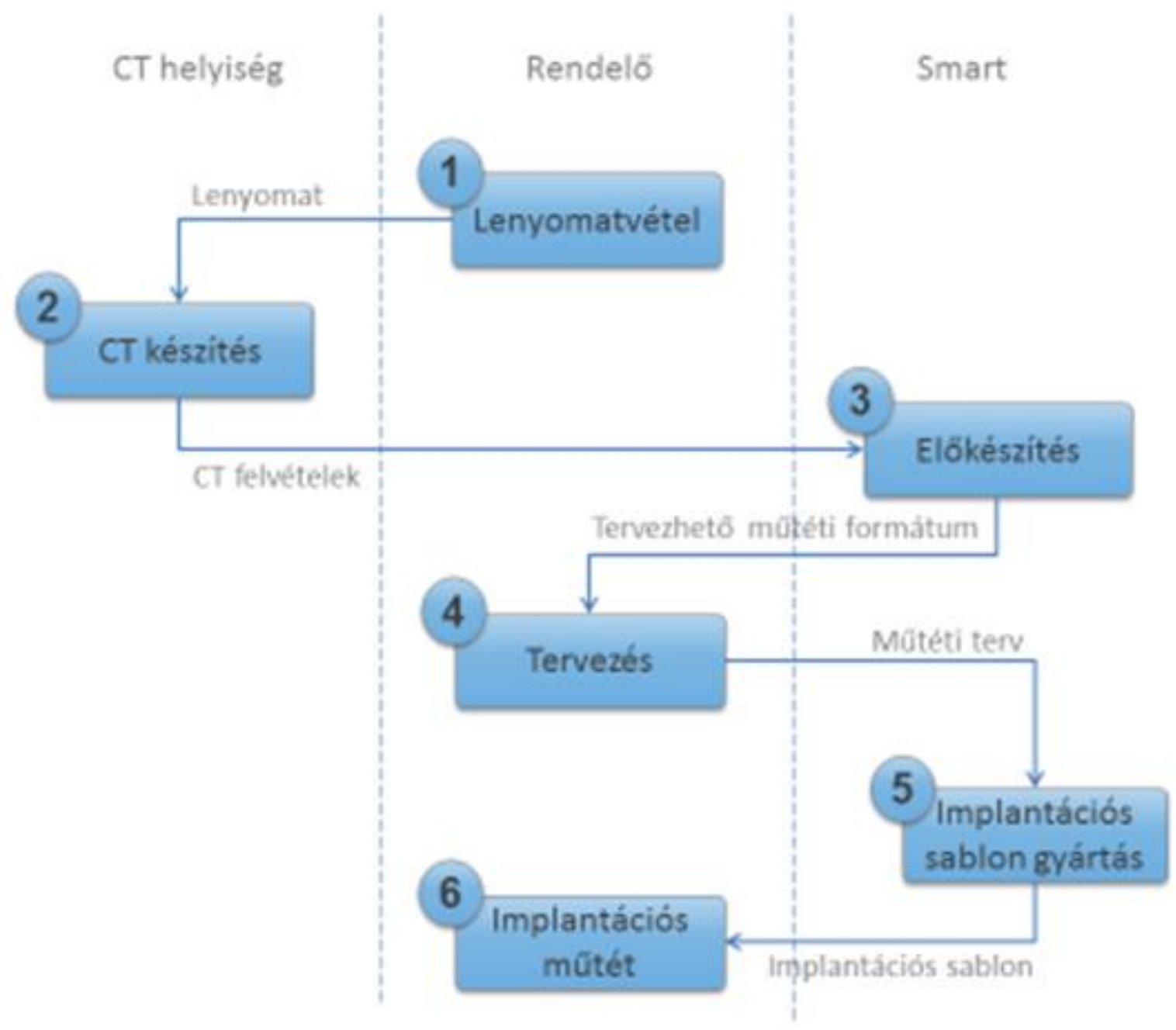




\section{2. ábra:}

Az implantációs sablon gyártás lépései.

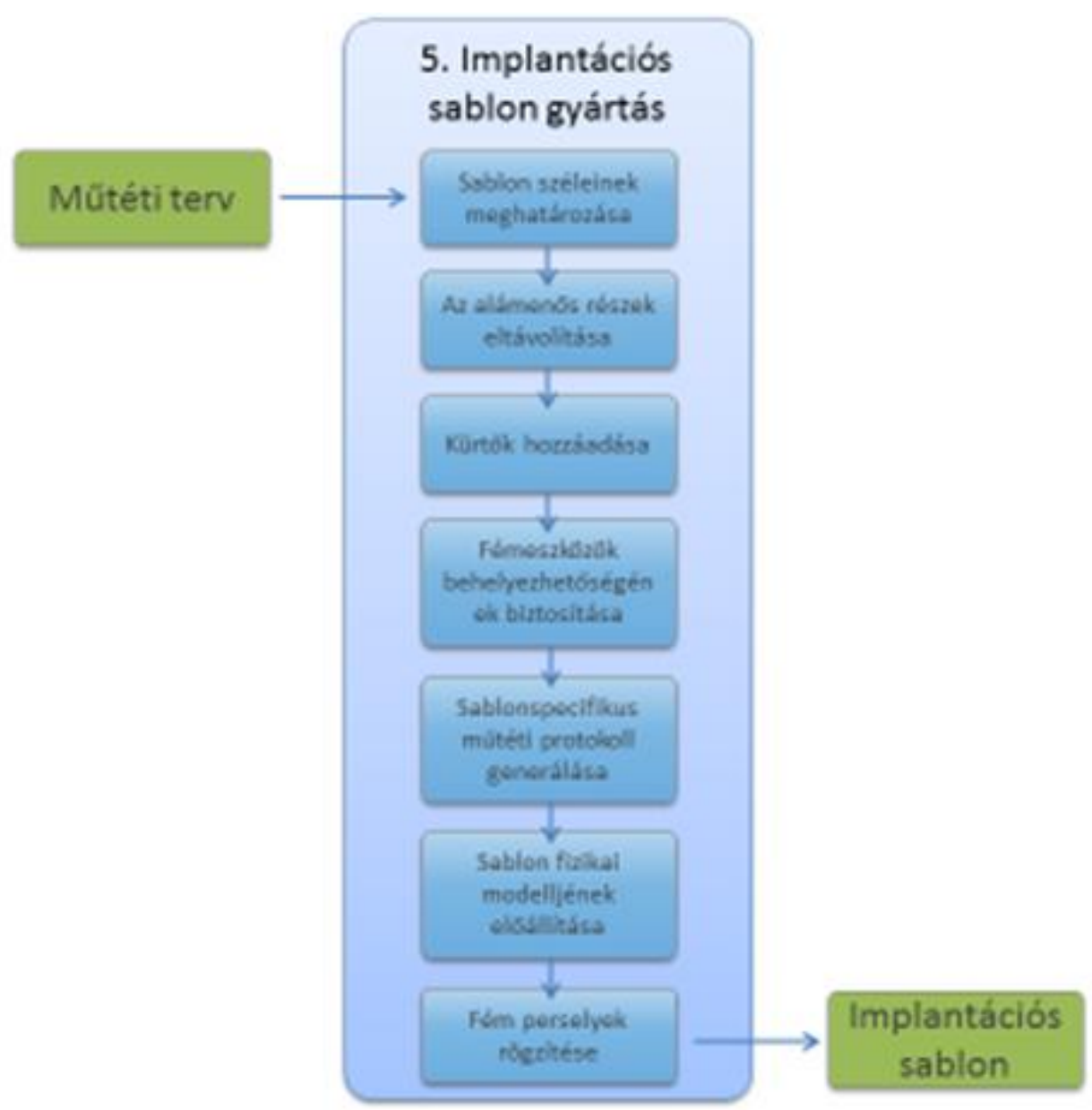

A következőkben részletesen ismertetjük találmányunkat.

A találmány szempontjából a „dual scan protokoll” kifejezés jelentése: a dual scan protokoll kettő CBCT felvétel készitését jelenti úgy, hogy az egyik felvételen a páciens szerepel szájában megfelelő helyen lévő, regisztrációs markerekkel ellátott lenyomatvételi kanállal és lenyomattal, míg a másik felvételen egyedül a markerekkel ellátott lenyomatvételi kanállal és a benne elhelyezkedő lenyomat szerepel.

A találmány szempontjából a „regisztrációs marker” kifejezés jelentése: a regisztrációs marker egy valamilyen röntgenárnyékot adó (esetünkben guttapercha) gömb test, melyből több helyezkedik el a lenyomatvételi kanálban, meghatározott számban és helyen. 
A találmány szempontjából az „összeregisztrálás” kifejezés jelentése: a dual-scan protokollnak megfelelően mindkét CBCT felvételen szerepel a regisztrációs markerekkel ellátott lenyomatvételi kanál a lenyomattal. Regisztrációnak nevezzük, amikor egy számítógépes program segítségével az azonos markereket összeillesztjük, így a két felvétel egy koordinátarendszerbe kerül a háromdimenziós térben.

A találmány szempontjából a „CT” vagy „CBCT” kifejezés jelentése: Computed Tomography vagy Cone Beam Computed Tomography, képalkotásra szolgáló eszköz, melynek képéből háromdimenziós képeket hozunk létre.

A találmány szempontjából a „persely” kifejezés jelentése: a persely egy fémből készült üreges henger, mely a háromdimenziós nyomtatóval elóállított műanyag sablon kürtôbe illeszkedik. Feladata a fúrók és egyéb eszközök pontos megvezetése.

A találmány szempontjából a „fémperselyeket befogadó kürtő” kifejezés jelentése: a háromdimenziós nyomtatóval előállított műanyag sablon formában kialakított lyuk, melynek belső átmérője megegyezik a persely külső átmérőjével. Feladata a fém perselyek helyes pozícionálása a tér minden irányában.

A találmány szempontjából az „alámenős részek” kifejezés jelentése: a fogak koronáinak, fogpótlások és egyéb szájüregi képletek legnagyobb átmérője alatti terület.

A találmány szempontjából a „pilot csontfészek” kifejezés jelentése: az első olyan furat a csontban, mely a furat teljes mélységét megadja.

A találmány szempontjából az „univerzális csontfészek” kifejezés jelentése: A pilot furat tágításával univerzális méretű furatot érünk el a csontban.

A találmány ismertetésében szereplő a „SMART Guide” kifejezés a jelen találmány szerinti eljárás és rendszer megjelölésére vonatkozó védjegy.

A találmány ismertetésében szereplő „JGuide” kifejezés az említett, jelen találmány szerinti rendszer által magában foglalt sablontervező szoftverre vonatkozó védjegy. 
A találmány tárgya eljárás implantációs sablon tervezésére és előállitására alkalmas rendszerben, ahol a rendszer magában foglal olyan lenyomatvételre alkalmas kanalat, amely a dual scan protokollhoz szükséges beépített regisztrációs markereket tartalmaz, és lenyomatvételre alkalmas anyaggal tölthető fel. A találmány szerinti eljárás magában foglalja, hogy a páciens szájüregi képleteirôl lenyomatot készítünk az említett kanállal. Helyben készülő CT-felvétel esetén anélkül, hogy a páciens szájából eltávolítanánk a kanalat, elkészítjük az első CT-felvételt. Nem helyben készülő lenyomatvétel esetén, a lenyomatot vissza kell helyezni a szájba. Ezt követően a páciens szájából eltávolítjuk a kanalat, amiről külön készítünk egy második CT-felvételt. A két CT-felvétel elkészítése (kanál a lenyomattal + páciens, illetve a kanál a lenyomattal önmagában) megfelel a dual scan protokollnak, azonban itt nincs szükség fogtechnikus által előzőleg elkészített gipszmintára és radiológiai sablonra. A jelen találmány szerinti kanállal készült lenyomat a szájüregi képletek negatív mását adja.

A találmány szerinti eljárás további lépésében a dual scan protokoll alapján készült két felvételt összeregisztráljuk.

A találmány szerinti eljárás további lépésben a képi regisztrációt követően egy mútéti tervező számítógépes program segítségével megtervezzük az implantációs műtétet. Az implantációs műtéti terv elkészítésébe beleértendő a megfelelő implantátumok típusának és méretének kiválasztása, az implantátumok helyének és helyzetének meghatározása, az implantáció elvégzéséhez szükséges sebészeti eszközöket tartalmazó sebészeti tálca kiválasztása.

Az implantációs mútéti terv interneten eljut egy sablontervező számítógépes programba.

A digitalizált lenyomaton a sablontervező számítógépes program segítségével kijelöljük a sablon határait, meghatározzuk a sablon vastagságát és formavilágát. Ennek megfelelően tehát a fogtechnikus a digitalizált negatív lenyomaton végzi el azokat a múveleteket, amelyeket a technika állása szerint egy fizikai sablonon manuálisan kellene végrehajtania.

A találmány szerinti eljárás további lépésében az említett sablontervező számítógépes program segítségével az implantációs sablon digitális modelljének tervezése során egy meghatározott iránynak megfelelően eltávolítjuk az alámenős részeket (undercuts). Ezen megoldásnak az a felismerés képezi az alapját, hogy ha a digitális modell kialakítása során, a végleges implantációs sablon anyagának megfelelően, tökéletesen rugalmatlan anyagot feltételezünk, akkor a sablon egy megadott behelyezési irányának megfelelően meghatározhatók az alámenős részek, amelyek eltávolításával biztosítható, hogy a végleges sablon a tökéletes pozícióba kerüljön vissza és 
tökéletesen illeszkedjen. A technika állása szerinti manuális eljáráshoz képest a találmányunk szerinti eljárás során ez a művelet egyszerúbben és sokkal gyorsabban, akár néhány másodperc alatt elvégezhető.

A találmány szerinti eljárás további lépésében az említett sablontervező számítógépes program segítségével az implantációs sablon digitális modelljének tervezése során a digitalizált lenyomat és az implantációs műtéti terv alapján meghatározzuk a sebészeti eszközök megvezetésére szolgáló fémperselyeket befogadó kürtők formáját és méretét.

A találmány szerinti eljárás további lépésében az említett sablontervező számítógépes program segítségével az implantációs sablon digitális modelljének tervezése során a digitalizált lenyomat és az implantációs műtéti terv alapján biztosítjuk az implantációs fémeszközök behelyezhetőségét.

A találmány szerinti eljárás további lépésében az említett sablontervező számítógépes program segítségével az implantációs sablon digitális modelljének tervezése során elhelyezzük az eset egyedi azonosítóját.

A találmány szerinti eljárás további lépésében az említett sablontervező számítógépes program segítségével az implantációs sablon digitális modelljének tervezése során a módosított digitalizált lenyomat és az implantációs mútéti terv alapján egy sablonspecifikus mútéti (fúrási) protokollt határozunk meg.

A találmány szerinti eljárás további lépésében a módosított digitalizált lenyomat és az implantációs mútéti terv alapján az említett sablontervező számítógépes programmal elkészítjük a végleges implantációs sablon digitális modelljét, amelynek fizikai megfelelőjét 3D-s nyomtatással állítjuk elő. Ezt követően az implantációs eszközök megvezetését szolgáló fémperselyeket rögzítjük a 3D-s nyomtatással elóállított sablonformába, így megkapjuk a végleges implantációs sablont.

A találmány egy előnyös kiviteli alakja szerinti mútéti tervező szoftver: 3D nézet; panoráma nézet; tervező nézet, idegpályák kijelölése és megjelenítése; ütközésvizsgálat implantátumok, rögzítőtüskék és perselyeik között; legyárthatatlan esetek szűrése; online rendelés a szoftverből, nem korlátozva azonban ezekre. 
A találmány egy előnyös kiviteli alakja szerinti sablontervező szoftver: a sablon szélének megadása, alámenős területek figyelembevételével garantált a felhelyezhetőség; ellenőrző ablakok; automatikus műtéti protokoll generálása; automatikus perselyezési (gyártási) útmutató generálása; szűkítő persely és kézidarab garantált hozzáférhetősége, ragasztási csatornák generálása, nem korlátozva azonban ezekre.

A jelen találmány szerinti eljárás lehetővé teszi egy vagy több fogimplantátum elhelyezésére, illetve rögzítő tüskék elhelyezésére szolgáló implantációs sablon előállítását.

A jelen találmány szerinti eljárás lehetővé teszi továbbá pilot vagy univerzális perselyekkel rendelkező sablonok előállítását.

A jelen találmány szerinti eljárás szintén lehetővé teszi fogra vagy lágyrészekre illeszkedő sablon előállítását.

A fentieknek megfelelően a találmány tárgya eljárás egy vagy több fogimplantátum elhelyezésére szolgáló fogászati implantációs sablon tervezésére és előállítására egy olyan rendszerben, ahol a rendszer magában foglal olyan lenyomatvételre alkalmas kanalat, amely a dual scan protokollhoz szükséges beépített regisztrációs markereket tartalmaz, és lenyomatvételre alkalmas anyaggal tölthető fel, és amely eljárás szerint a következő lépéseket hajtjuk végre (1. ábra):

1) a páciens szájüregi képleteirôl lenyomatot készítünk az említett kanállal;

2) készítünk egy CT felvételt a páciensről, szájában a megfelelő pozícióban lévő, lenyomatot tartalmazó említett lenyomatvételi kanállal, majd eltávolítjuk a kanalat a szájából és készítünk egy CT-felvételt külön a lenyomatvételi kanálról;

3) a dual scan protokoll alapján elkészül a felvételek regisztrációja és előáll a tervezhető mútéti formátum;

4) a képi regisztrációt követően egy műtéti tervező számítógépes program segítségével megtervezzük az implantációs mútétet, amelynek keretében a következő műveletek közül egyet, többet vagy az összeset tetszőleges sorrendben elvégezzük: a megfelelő implantátumok típusának és méretének kiválasztása, az implantátumok helyének és helyzetének meghatározása, az implantáció elvégzéséhez szükséges sebészeti eszközöket tartalmazó sebészeti tálca kiválasztása;

5) az implantációs műtéti terv alapján legyártjuk a mútéti sablont (2. ábra):

a) a digitalizált lenyomaton egy sablontervező számítógépes program segítségével kijelöljük a sablon határait, meghatározzuk a sablon vastagságát és formáját;

b) az említett sablontervező számítógépes program segítségével az implantációs sablon digitális modelljének tervezése során meghatározzuk a szájba helyezési irányt és ez alapján eltávolítjuk az 
alámenős részeket (undercuts), így biztosíthatjuk, hogy a végleges sablon a tökéletes pozícióba kerüljön és tökéletesen illeszkedjen;

c) az említett sablontervező számítógépes program segítségével az implantációs sablon digitális modelljének tervezése során a digitalizált lenyomat és az implantációs műtéti terv alapján meghatározzuk a sebészeti eszközök megvezetésére szolgáló fémperselyeket befogadó kürtők külső formáját és méretét;

d) az említett sablontervező számítógépes program segítségével az implantációs sablon digitális modelljének tervezése során a digitalizált lenyomat és az implantációs műtéti terv alapján biztosítjuk az implantációs fémeszközök és implantációs könyökdarab behelyezhetőségét;

e) az említett sablontervező számítógépes program segítségével az implantációs sablon digitális modelljének tervezése során a módosított digitalizált lenyomat és az implantációs műtéti terv alapján egy sablonspecifikus mútéti protokollt határozunk meg;

f) a módosított digitalizált lenyomat és az implantációs mûtéti terv alapján az említett sablontervező számítógépes programmal elkészítjük a végleges implantációs sablon digitális modelljét, amelynek fizikai megfelelőjét előnyösen 3D-s nyomtatással állítjuk elő;

g) ezt követően az implantációs eszközök megvezetését szolgáló fémperselyeket rögzítjük a 3D-s nyomtatással elóállított sablonformába, így megkapjuk a végleges implantációs sablont;

6) elvégezzük a mútétet a sablon és a műtéti eszközök segítségével, az egyedi műtéti protokoll alapján.

A találmány szerinti eljárás előnyös kiviteli alakjában az implantációs műtéti terület közelében a páciens rendelkezik olyan anatómia képlettel, általában egy vagy több foggal, amelyhez az implantációs sablon tervezése során a tervezett egy vagy több implantátum helye és helyzete, illetve tengelyállása viszonyítható.

Az előbbieknek megfelelően találmányunk tárgya továbbá eljárás, amely szerint a lépéseket olyan páciensen hajtjuk végre, aki az implantációs mútéti terület közelében rendelkezik olyan anatómiai képlettel, előnyösen egy vagy több foggal, amelyhez az implantációs sablon tervezése során a tervezett egy vagy több implantátum helye és helyzete, illetve tengelyállása viszonyítható.

A jelen találmány szerinti eljárás lehetővé teszi, hogy adott esetben már a pácienssel való első találkozáskor elkészülhessenek a CT-felvétek, így az orvos rövid időn belül elkezdheti az implantáció tervezését. Nincs szükség a fogtechnikus technika állása szerinti többlépéses, időigényes (akár több napot is igénylő) és költséges munkafolyamatára, ami elsősorban a páciens 
szempontjából kedvezőtlen. A találmányunk tehát a gyakorlati megvalósítás, az idő és költség szempontjából egyaránt hatékonyabb megoldást kínál.

Az előbbieknek megfelelően találmányunk tárgya továbbá eljárás, amely szerint a lépéseket egyetlen helyszínen és/vagy a műveletek megkezdésétől számított 48 órán belül, előnyösen 24 órán belül, legelőnyösebben 12 órán belül vagy ennél is rövidebb idő alatt végezzük el.

Az előbbieknek megfelelően a találmányunk tárgya továbbá eljárás, amely tartalmazza még, hogy az implantációs sablon elóállítása során az említett sablontervező számítógépes programmal elhelyezzük az eset egyedi azonosítóját, és/vagy az említett implantációs műtéti tervet interneten juttatjuk el az említett sablontervező számítógépes programhoz.

A találmány tárgya továbbá rendszer implantációs sablon tervezésére és előállítására, amely tartalmazza az alábbiakat:

- A találmány szerinti lenyomatvételre alkalmas kanál, amely a dual scan protokollhoz szükséges beépített regisztrációs markereket tartalmaz, és lenyomatvételre alkalmas anyaggal tölthetô fel.

- A találmány szerinti műtéti tervező számítógépes programmal (SMART Guide szoftver) ellátott számítógép az implantációs mútéti terv elkészítésére.

- A találmány szerinti sablontervező számítógépes programmal (JGuide szoftver) ellátott számítógép a módosított digitalizált lenyomat előallítására, a végleges implantációs sablon tervezésére.

- Az említett implantációs mútéti tervben meghatározott sebészeti tálca, amely tartalmazza a találmány szerinti eljárással előállított implantációs sablon rögzítéséhez szükséges eszközöket, a csontfészek előkészítéséhez szükséges fúrókat, a mútéti eszközök pontos megvezetéséhez szükséges szúkítőperselyeket, a pilot és az univerzális csontfészkek kialakításához szükséges eszközöket, illetve az implantátum behelyezése után annak pontos pozíciójának visszamérésére szolgáló eszközt.

- A találmány szerinti eljárással megtervezett és előállított implantációs sablon.

Az előbbieknek megfelelően a találmány tárgya továbbá rendszer implantációs sablon tervezésére és előállítására, amely tartalmazza az alábbi elemeket: 
a) lenyomatvételre alkalmas kanál, amely a dual scan protokollhoz szükséges beépített regisztrációs markereket tartalmaz, és lenyomatvételre alkalmas anyaggal tölthetô fel;

b) műtéti tervező számítógépes programmal ellátott számítógép az implantációs műtéti terv elkészítésére;

c) sablontervezô számítógépes programmal ellátott számítógép a módosított digitalizált lenyomat előállítására, a végleges implantációs sablon tervezésére;

d) egy implantációs műtéti tervben meghatározott sebészeti tálca, amely tartalmaz a következők közül egy, több vagy minden eszközt: implantációs sablon rögzítéséhez szükséges eszközök, a csontfészek előkészítéséhez szükséges fúrókat, a mútéti eszközök pontos megvezetéséhez szükséges szúkítôperselyeket, a pilot és az univerzális csontfészkek kialakításához szükséges eszközöket, illetve az implantátum behelyezése után annak pontos pozíciójának visszamérésére szolgáló eszközt;

e) a találmány szerinti eljárással megtervezett és előállított implantációs sablon.

A fentieknek megfelelően a találmány tárgya továbbá rendszer, amelyben a mútéti tervező szoftver a következő funkciók közül eggyel, többel vagy mindegyikkel rendelkezik: 3D nézet; tervező nézet, panoráma nézet; idegpályák kijelölése és megjelenítése; ütközésvizsgálat implantátumok, rögzítőtüskék és perselyeik között; legyárthatatlan esetek szűrése; online rendelés a szoftverből.

A fentieknek megfelelően a találmány tárgya továbbá rendszer, amelyben a sablontervező szoftver a következő funkciók közül eggyel, többel vagy mindegyikkel rendelkezik: a sablon szélének megadása, alámenős területek figyelembevételével garantált a felhelyezhetőség; ellenőrző ablakok; automatikus mútéti protokoll generálása; automatikus perselyezési (gyártási) útmutató generálása; szúkítő persely és kézidarab garantált hozzáférhetősége, ragasztási csatornák generálása.

A találmány szerinti eljárás implantációs sablon tervezésére alkalmas rendszerben lehetővé teszi az implantációs sablon tervezéséhez és előállításához szükséges információ on-line (azaz közvetlen kapcsolaton alapuló) közvetítését a CT-labor, a fogorvosi rendelő és az implantációs sablont előállító hely között.

A fentieknek megfelelően a találmány tárgya továbbá eljárás, amely szerint az implantációs sablon tervezéséhez és előállitásához szükséges információt on-line közvetítjük a CT-labor, a fogorvosi rendelő és az implantációs sablont előállító hely között. 
A fentieknek megfelelően a találmány tárgya továbbá rendszer, amely az implantációs sablon tervezéséhez és előállításához szükséges információt on-line közvetíti a CT-labor, a fogorvosi rendelő és az implantációs sablont elóállító hely között.

A találmány szerinti eljárás implantációs sablon tervezésére alkalmas rendszerben lehetővé teszi továbbá, hogy az implantációs sablon mint végtermék a lehető legkevesebb emberi érintéssel készülhessen el. A „lehető legkevesebb emberi érintés” kifejezést a találmány szempontjából úgy kell értelmezni, hogy az implantációs sablon elóállítása során a terméket csak a 3D-s nyomtatás utómunkálatai, illetve a fémperselyek sablonformába történő rögzítése során érintik kézzel.

Az előbbieknek megfelelően a találmány tárgya továbbá eljárás, amely szerint az implantációs sablon előállítása során a terméket csak a 3D-s nyomtatás utómunkálatai, illetve a fémperselyek sablonformába történő rögzítése során érintjük kézzel.

A fentiek alapján a találmány tárgya továbbá eljárás és rendszer, ahol az említett lenyomatvételre alkalmas kanál egy vagy több beépített, előnyösen 6-8 darab dual CT protokoll elvégzéséhez szükséges regisztrációs markert tartalmaz.

A találmány tárgya továbbá eljárás és rendszer, ahol az említett lenyomatvételre alkalmas kanál alsó vagy felső állkapocsra illeszkedő kivitelben készül.

A találmány tárgya továbbá eljárás és rendszer, ahol a lenyomatvételre alkalmas anyag szilikon vagy alginát.

Az előbbieknek megfelelően a találmány tárgya eljárás vagy rendszer alkalmazása fogászati beavatkozások kivitelezésére, előnyösen fogpótlásra, előnyösebben fogimplantátum elhelyezésére, pilot vagy univerzális perselyekkel rendelkező sablonok elóállítására, fogra vagy lágyrészekre illeszkedő sablon előállítására.

A találmány szempontjából a „radiodens marker” és a „regisztrációs marker” kifejezéseket egymással felcserélhető módon alkalmazzuk. 
Továbbá a találmány szempontjából a „dual scan protokoll”, a „double scan protokoll” és a „dual CT protokoll” kifejezéseket egymással felcserélhető módon alkalmazzuk.

A következőkben találmányunkat kiviteli példákkal illusztráljuk, amelyeket azonban nem kívánunk a találmány korlátozásaként értelmezni.

1. példa: SMART Guide kanál

A találmány szerinti lenyomatvételre alkalmas kanál jellemzői:

- Egy vagy több, előnyösen 6-8 darab beépített, a dual CT protokoll elvégzéséhez szükséges regisztrációs markert tartalmaz.

- Alsó vagy felső állkapocsra illeszkedő kivitelben készül.

- Három különböző méretű (S, M és L méretű) kivitelben készül.

- Lenyomatanyaggal tölthető fel az implantációs területről készítendő lenyomatvételhez.

2. példa: SMART Guide implantációs sablon előállitása SMART Guide kanál alkalmazásával. A találmány szerinti SMART Guide kanál tartalmazza a dual CT protokoll elvégzéséhez szükséges regisztrációs markereket, így azok elhelyezésével nem kell törődni. A SMART Guide kanál és a találmányszerinti eljárás alkalmazásával nem kell radiológiai sablont készíteni.

- Kiválasztjuk a találmány szerinti, megfelelő méretú alsó vagy felső állkapocsra illeszkedő kanalat.

- Lenyomatanyagot, előnyösen szilikont vagy alginátot helyezünk a kanálba.

- Lenyomatot készítünk az implantációs területről a lenyomatanyaggal ellátott kanállal.

- Adott esetben lenyomatanyag megkötése után harapás regisztrációt végzünk harapásvételre alkalmas anyaggal, előnyösen szilikonnal vagy viasszal a megkötött lenyomatanyagot tartalmazó kanállal.

- Adott esetben, kevés ellenoldali fog esetén az állcsontgerincek területét feltöltjük harapás regisztrációt rögzítő anyaggal a kanál megfelelő pozícióban tartásához.

- Adott esetben az alámenős részeket eltávolítjuk a lenyomatból, majd elvégezzük a kanál és a harapás regisztráció próbáját.

- Adott esetben, nem helyben készülő CT felvétel esetén a pácienssel gyakoroltatjuk a kanál és a harapás visszahelyezését.

- A lenyomatot digitalizáljuk a dual CT protokollnak megfelelően (CT1: páciens a kanállal, CT2: kanál). 
- A CT felvételeket hozzáférhetôvé tesszük a találmány szerinti számítógépes programmal ellátott számítógép számára, mely a tervezést hivatott elvégezni.

- Az mútéti tervező programmal ellátott számítógépen a CT felvételeket összeregisztráljuk, és az összeregisztrált felvételeket hozzáférhetôvé tesszük a találmány szerinti mútéti tervező számítógépes programmal ellátott számítógépnek, amely a tervezést végző orvos által elérhetô.

- Az összeregisztrált CT felvételek alapján a tervező programmal ellátott számítógépen elkészítjük az implantációs műtéti tervet.

- Az implantációs mútéti terv alapján a gyártó programmal ellátott számítógépen megtervezzük és 3D nyomtatóval előállítjuk a végleges implantációs sablont.

3. példa: SMART Guide implantációs sablon előállítása radiológiai sablon alkalmazásával.

- Lenyomatot készítünk a tanulmányi minta számára.

- Elvégezzük a diagnosztikus fogfelállítás.

- Elkészítjük a radiológiai sablont és azon elhelyezzük a regisztrációs markereket.

- Harapás regisztrációt végzünk.

- Elvégezzük a lenyomat digitalizálását a dual CT protokollnak megfelelően (CT1: páciens a radiológiai sablonnal, CT2: radiológiai sablon).

- Elvégezzük a 2. példában ismertetett, dual CT protokoll végrehajtását követő lépéseket.

4. példa: SMART Guide implantációs sablon előállítása teljes kivehető fogpótlás esetén.

- A kivehető fogpótlást ellátjuk regisztrációs markerekkel.

- Ha szükséges, harapás regisztrációt végzünk.

- Elvégezzük a lenyomat digitalizálását a dual CT protokollnak megfelelően (CT1: páciens a teljes kivehető fogpótlással, CT2: teljes kivehető fogpótlás).

- Elvégezzük a 2. példában ismertetett, dual CT protokoll végrehajtását követő lépéseket.

Ipari alkalmazhatóság

A találmány megoldást kínál fogimplantációs sablon egyszerű, gyors, pontos és költséghatékony előállítására. A találmány szerinti eljáráshoz és rendszerhez nem szükséges radiológiai sablon előállítása, amely többlépéses, fejlett kézügyességet igénylő, következésképpen időigényes és költséges munkafolyamat. Ugyanakkor a találmány szerinti megoldás támogatást nyújt mindazon 
műveletek gyors és egyszerú végrehajtásához, amelyek egy implantációs sablon tervezéséhez és előállításához szükségesek. Következésképpen a találmány szerinti eljárás és rendszer megkönnyíti, hogy az implantációs sablonokkal végzendő beavatkozások beilleszthetők legyenek a mindennapi rendelői rutinba. 


\section{SZABADALMI IGÉNYPONTOK}

1. Eljárás egy vagy több fogimplantátum elhelyezésére szolgáló fogászati implantációs sablon tervezésére és elóállítására egy olyan rendszerben, ahol a rendszer magában foglal olyan lenyomatvételre alkalmas kanalat, amely a dual scan protokollhoz szükséges beépített regisztrációs markereket tartalmaz, és lenyomatvételre alkalmas anyaggal tölthető fel, azzal jellemezve, hogy a következô lépéseket hajtjuk végre:

1) a páciens szájüregi képleteiről lenyomatot készítünk az említett kanállal;

2) készítünk egy CT felvételt a páciensről, szájában a megfelelő pozícióban lévő, lenyomatot tartalmazó említett lenyomatvételi kanállal, majd eltávolítjuk a kanalat a szájából és készítünk egy CT-felvételt külön a lenyomatvételi kanálról;

3) a dual scan protokoll alapján elkészül a felvételek regisztrációja és elóáll a tervezhető mútéti formátum;

4) a képi regisztrációt követően egy mútéti tervező számítógépes program segítségével megtervezzük az implantációs műtétet, amelynek keretében a következő műveletek közül egyet, többet vagy az összeset tetszőleges sorrendben elvégezzük: a megfelelő implantátumok típusának és méretének kiválasztása, az implantátumok helyének és helyzetének meghatározása, az implantáció elvégzéséhez szükséges sebészeti eszközöket tartalmazó sebészeti tálca kiválasztása;

5) az implantációs mûtéti terv alapján legyártjuk a mútéti sablont:

a) a digitalizált lenyomaton egy sablontervező számítógépes program segítségével kijelöljük a sablon határait, meghatározzuk a sablon vastagságát és formáját;

b) az említett sablontervező számítógépes program segítségével az implantációs sablon digitális modelljének tervezése során meghatározzuk a szájba helyezési irányt és ez alapján eltávolítjuk az alámenős részeket (undercuts), így biztosíthatjuk, hogy a végleges sablon a tökéletes pozícióba kerüljön és tökéletesen illeszkedjen;

c) az említett sablontervező számítógépes program segítségével az implantációs sablon digitális modelljének tervezése során a digitalizált lenyomat és az implantációs mútéti terv alapján meghatározzuk a sebészeti eszközök megvezetésére szolgáló fémperselyeket befogadó kürtők külső formáját és méretét;

d) az említett sablontervező számítógépes program segítségével az implantációs sablon digitális modelljének tervezése során a digitalizált lenyomat és az implantációs műtéti terv alapján biztosítjuk az implantációs fémeszközök és implantációs könyökdarab behelyezhetőségét; 
e) az említett sablontervező számítógépes program segítségével az implantációs sablon digitális modelljének tervezése során a módosított digitalizált lenyomat és az implantációs mútéti terv alapján egy sablonspecifikus műtéti protokollt határozunk meg;

f) a módosított digitalizált lenyomat és az implantációs mútéti terv alapján az említett sablontervező számítógépes programmal elkészítjük a végleges implantációs sablon digitális modelljét, amelynek fizikai megfelelőjét előnyösen 3D-s nyomtatással állítjuk elő;

g) ezt követôen az implantációs eszközök megvezetését szolgáló fémperselyeket rögzítjük a 3D-s nyomtatással elóállított sablonformába, így megkapjuk a végleges implantációs sablont;

6) elvégezzük a műtétet a sablon és a műtéti eszközök segítségével, az egyedi mútéti protokoll alapján.

2. Az 1. igénypont szerinti eljárás, azzal jellemezve, hogy a lépéseket olyan páciensen hajtjuk végre, aki az implantációs mútéti terület közelében rendelkezik olyan anatómiai képlettel, előnyösen egy vagy több foggal, amelyhez az implantációs sablon tervezése során a tervezett egy vagy több implantátum helye és helyzete, illetve tengelyállása viszonyítható.

3. Az 1. vagy 2. igénypont szerinti eljárás, azzal jellemezve, hogy a lépéseket egyetlen helyszínen és/vagy a műveletek megkezdésétől számított 48 órán belül, előnyösen 24 órán belül, legelőnyösebben 12 órán belül vagy ennél is rövidebb idő alatt végezzük el.

4. Az 1-3. igénypontok bármelyike szerinti eljárás, azzal jellemezve, hogy az implantációs sablon tervezéséhez és előállitásához szükséges információt on-line közvetítjük a CT-labor, a fogorvosi rendelő és az implantációs sablont előállító hely között.

5. Az 1-4. igénypontok bármelyike szerinti eljárás, azzal jellemezve, hogy az implantációs sablon elóállítása során a terméket csak a 3D-s nyomtatás utómunkálatai, illetve a fémperselyek sablonformába történő rögzítése során érintjük kézzel.

6. Az 1-5. igénypontok bármelyike szerinti eljárás tartalmazza továbbá, hogy az implantációs sablon előállítása során az említett sablontervező számítógépes programmal elhelyezzük az eset egyedi azonosítóját, és/vagy az említett implantációs műtéti tervet interneten juttatjuk el az említett sablontervező számítógépes programhoz.

7. Rendszer implantációs sablon tervezésére és elóállítására, amely tartalmazza az alábbi elemeket: 
a) lenyomatvételre alkalmas kanál, amely a dual scan protokollhoz szükséges beépített regisztrációs markereket tartalmaz, és lenyomatvételre alkalmas anyaggal tölthetô fel;

b) mủtéti tervező számítógépes programmal ellátott számítógép az implantációs mủtéti terv elkészítésére;

c) sablontervezô számítógépes programmal ellátott számítógép a módosított digitalizált lenyomat előállítására, a végleges implantációs sablon tervezésére;

d) egy implantációs műtéti tervben meghatározott sebészeti tálca, amely tartalmaz a következők közül egy, több vagy minden eszközt: implantációs sablon rögzítéséhez szükséges eszközök, a csontfészek előkészítéséhez szükséges fúrókat, a mútéti eszközök pontos megvezetéséhez szükséges szúkítôperselyeket, a pilot és az univerzális csontfészkek kialakításához szükséges eszközöket, illetve az implantátum behelyezése után annak pontos pozíciójának visszamérésére szolgáló eszközt;

e) az 1-6. igénypontok bármelyike szerinti eljárással megtervezett és elóállított implantációs sablon.

8. A 7. igénypont szerinti rendszer, amely az implantációs sablon tervezéséhez és előállításához szükséges információt on-line közvetíti a CT-labor, a fogorvosi rendelő és az implantációs sablont előállító hely között.

9. A 7-8. igénypontok szerinti rendszer, amelyben a mútéti tervező szoftver a következő funkciók közül eggyel, többel vagy mindegyikkel rendelkezik: 3D nézet; tervező nézet; panoráma nézet; idegpályák kijelölése és megjelenítése; ütközésvizsgálat implantátumok, rögzítőtüskék és perselyeik között; legyárthatatlan esetek szűrése; online rendelés a szoftverből.

10. A 7-9. igénypontok szerinti rendszer, amelyben a sablontervező szoftver a következő funkciók közül eggyel, többel vagy mindegyikkel rendelkezik: a sablon szélének megadása, alámenős területek figyelembevételével garantált a felhelyezhetőség; ellenőrző ablakok; automatikus műtéti protokoll generálása; automatikus perselyezési (gyártási) útmutató generálása; szűkítő persely és kézidarab garantált hozzáférhetősége, ragasztási csatornák generálása.

11. Az 1-6. igénypontok bármelyike szerinti eljárás vagy a 7-10. igénypontok bármelyike szerinti rendszer, azzal jellemezve, hogy az említett lenyomatvételre alkalmas kanál egy vagy több beépített, dual CT protokoll elvégzéséhez szükséges regisztrációs markert tartalmaz. 
12. Az 1-6. igénypontok bármelyike szerinti eljárás vagy a 7-10. igénypontok bármelyike szerinti rendszer, azzal jellemezve, hogy az említett lenyomatvételre alkalmas kanál 6-8 darab beépített dual CT protokoll elvégzéséhez szükséges regisztrációs markert tartalmaz.

13. Az 1-6. igénypontok bármelyike szerinti eljárás vagy a 7-10. igénypontok bármelyike szerinti rendszer, azzal jellemezve, hogy az említett lenyomatvételre alkalmas kanál alsó vagy felső állkapocsra illeszkedő kivitelben készül.

14. Az 1-6. igénypontok bármelyike szerinti eljárás vagy a 7-10. igénypontok bármelyike szerinti rendszer, azzal jellemezve, hogy a lenyomatvételre alkalmas anyag szilikon vagy alginát.

15. Az 1-14. igénypontok bármelyike szerinti eljárás vagy rendszer alkalmazása fogászati beavatkozások kivitelezésére, előnyösen fogpótlásra, előnyösebben fogimplantátum elhelyezésére, pilot vagy univerzális perselyekkel rendelkező sablonok előállítására, fogra vagy lágyrészekre illeszkedő sablon előállítására. 


\section{ELJÁRÁS ÉS RENDSZER IMPLANTÁCIÓS SABLON TERVEZÉSÉRE ÉS ELŐÁLLÍTÁSÁRA}

\section{Kivonat}

A találmány tárgya eljárás implantációs sablon tervezésére és előállitására alkalmas rendszerben, ahol az eljárás tartalmazza, hogy szájképletrôl regisztrációs markerekkel ellátott kanállal lenyomatot készítünk; digitalizáljuk a lenyomatot; digitalizáljuk a beteget a lenyomattal a szájában; egy műtéti tervező számítógépes programmal összeregisztráljuk a két digitalizált képet, majd mútéti tervet készítünk; egy sablontervező számítógépes programmal a mútéti terv alapján elkészítjük az implantációs sablon digitális modelljét; az implantációs sablon digitális modellje alapján előállítjuk az implantációs sablon fizikai megfelelőjét. A találmány tárgya továbbá rendszer implantációs sablon tervezésére és elóállítására, amely tartalmaz lenyomatvételre alkalmas, regisztrációs markerekkel ellátott kanalat; egy műtéti tervező számítógépes programmal ellátott számítógépet a regisztráció elvégzésére és a műtéti terv elkészítésére; egy sablontervező számítógépes programmal ellátott számítógépet az implantációs sablon tervezésére és előállítására; a mútéti terv szerinti sebészeti tálcát; és a találmány szerinti eljárással megtervezett és előállított implantációs sablont. 